BRIDGING THE CULTURAL DIVIDE:

THE ROLE OF FOREIGN DIRECTORS IN CROSS-BORDER MERGERS

A Dissertation
presented to
the Faculty of the Graduate School
at the University of Missouri-Columbia
In Partial Fulfillment
of the Requirements for the Degree
Doctor of Philosophy
by
YAQOUB ALABDULLAH
Professor Stephen P. Ferris, Dissertation Supervisor
July 2014


(C) Copyright by Yaqoub Alabdullah 2014

All Rights Reserved 
The undersigned, appointed by the dean of the Graduate School, have examined the dissertation entitled

BRIDGING THE CULTURAL DIVIDE:

THE ROLE OF FOREIGN DIRECTORS IN CROSS-BORDER MERGERS

presented by Yaqoub Alabdullah,

a candidate for the degree of doctor of philosophy,

and hereby certify that, in their opinion, it is worthy of acceptance.

Professor Stephen Ferris

Professor Dan French

Professor John Howe

Professor Paul Speckman 


\section{DEDICATION}

First and foremost, I would like to thank Allah for everything that happened in my life. Then, I would like to thank all of my family members. I thank Mom for everything. Nothing that I do can really pay you back. Thank you Dad for setting the best example of how successful a man can be. Thanks Fatma for being my best friend and soul mate. The fact that you were with me from day one means the world to me. Thank you my brothers and sisters for all of your encouragement. Thank you my brother Sulaiman for all of your support. I pray to Allah that I meet you in heaven. I thank my children for giving me the encouragement to work hard so I can provide you with an excellent future. I thank Mama Ghanima and Mama Fawzia. 


\section{ACKNOWLEDGEMENTS}

I would like to thank Professor Stephen Ferris for being more than just a mentor for me. He dedicates all his time to his students and tries to help them as much as possible. Personally, he was with me since day one. Not only was he an academic father for me, he also helped me in my professional and personal lives. Being a PhD student, I went through a roller coaster of emotions throughout my years in Mizzou. Professor Ferris was always accessible and helped me as much as he could. To be honest, I would not have dreamed of having a better adviser. I just hope that my relationship with him will continue throughout the years to come.

I would also like to thank all the Professors at the Finance Department in the University of Missouri. I would like to specially thank Professors John Howe and Dan French for their advice on my career. This department is truly unique in that the relationship between students and Professors is without borders. All the Professors are easily accessible to all $\mathrm{PhD}$ students and they offer professional advice that really helps their students.

I would like to thank all my colleagues in University of Missouri and Kuwait University. Specially, I would like to thank David Javakhadze, Michael Gibbs and Scott O'Brien from Mizzou. I would also like to thank Professors Fahad Almudhaf and Bader Alhashel from Kuwait University for all of their advice and friendship that truly provided me with a unique perspective on lots of issues both in finance and my personal life. 


\section{TABLE OF CONTENTS}

ACKNOWLEDGEMENTS

LIST OF TABLES

vi

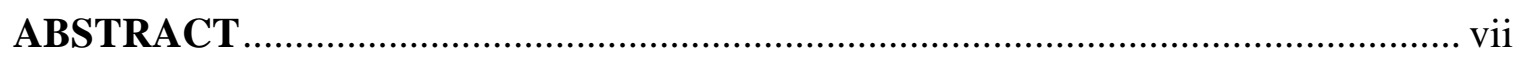

Chapter 1. INTRODUCTION ................................................

Chapter 2. THEORETICAL DISCUSSION OF THE EFFECT OF OUTSIDERS...9

I. Homophilic effects on group effectiveness .................................... 9

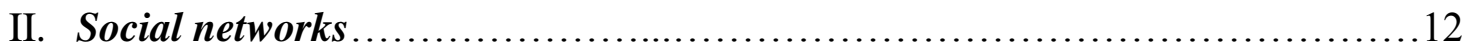

III. The effect of group heterogeneity .............................................

IV. The groupthink phenomenon ............................................. 16

Chapter 3. HYPOTHESES DEVELOPMENT .................................... 19

I. Merger activity and foreign directors ........................................ 19

1. Informational, legal and cultural effects on cross-border merger

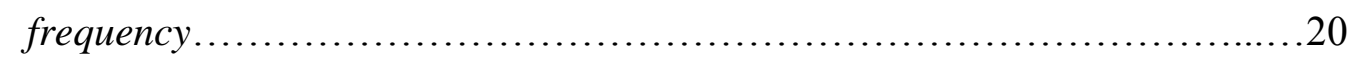

1.1 Informational challenges...............................20

1.2 Legal challenges.......................................22

1.3 Cultural challenges.......................................24

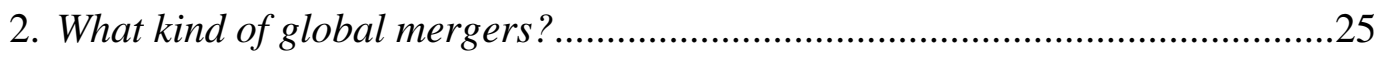

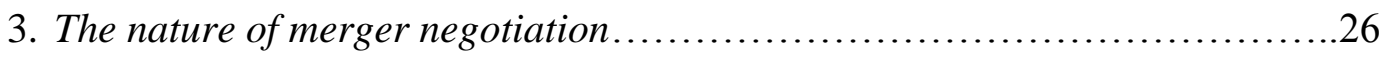

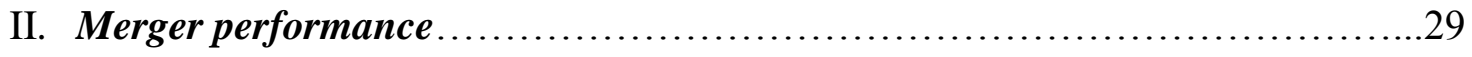

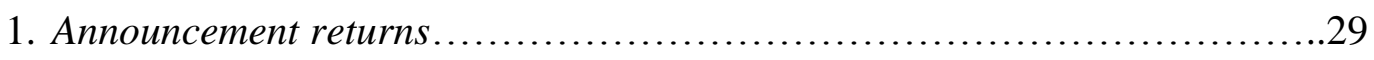


2. Investor protection and accounting standard effect............................ 31

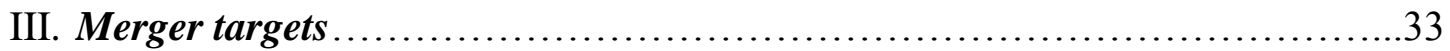

1. Types of targets................................................ 33

2. Valuation of the target............................................. 35

IV. Merger payment.................................................. 37

1. Merger premium ................................................. 37

2. Method of payment............................................... 39

Chapter 4. DATA SOURCES AND SAMPLE CONSTRUCTION .................42

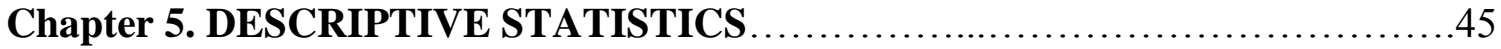

Chapter 6. EMPIRICAL ANALYSIS AND RESULTS $\ldots \ldots \ldots \ldots \ldots \ldots \ldots \ldots \ldots \ldots . \ldots \ldots$

I. Cross-border merger activity .......................................... 48

1. The effect offoreign directors on the incidences of cross-border mergers

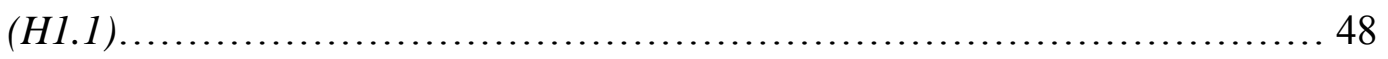

2. Foreign directors and the nature of diversifying merger activity (H1.2).......52

3. Foreign directors and the nature of merger negotiations $(H 1.3) \ldots \ldots \ldots \ldots \ldots . . . . .54$

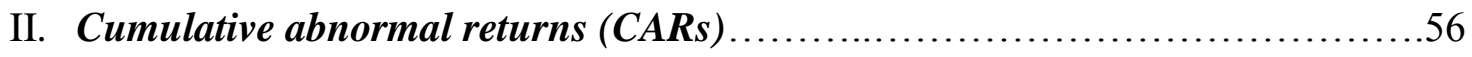

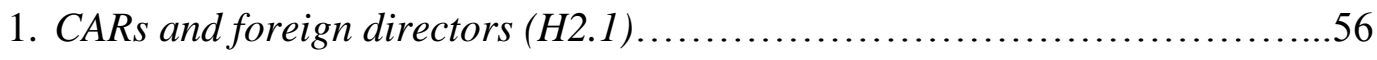

2. Foreign directors, investor protection and accounting standards

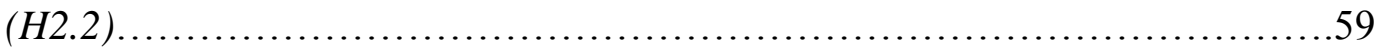

III. Foreign directors and merger targets ................................62

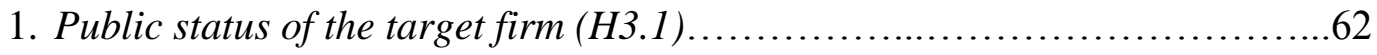

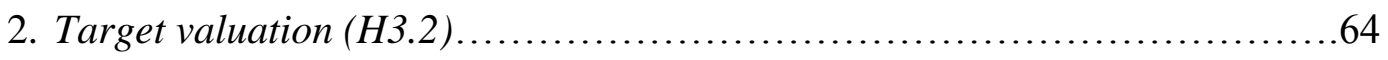


IV. Foreign directors and cross-border merger payment.

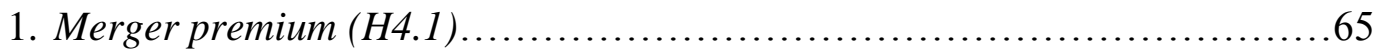

2. Foreign directors and the method of payment $(H 4.2) \ldots \ldots \ldots \ldots \ldots \ldots \ldots \ldots \ldots . . . \ldots 6$

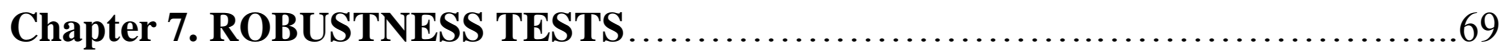

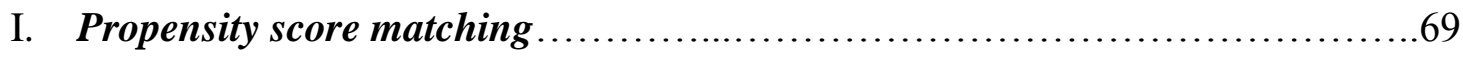

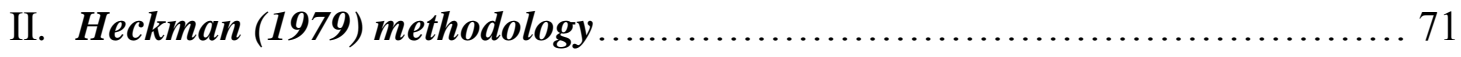

III. Concluding remarks on robustness tests....................................73

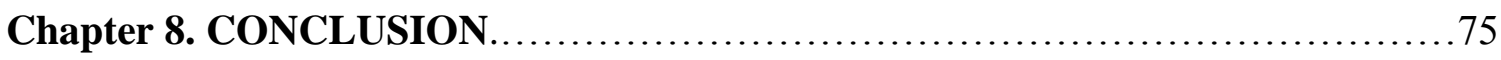

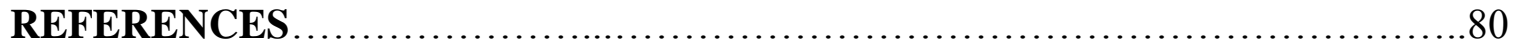

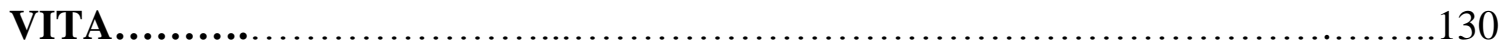




\section{LIST OF TABLES}

Table 1: Distribution of sample firms and foreign directors........................88

Table 2: Profile statistics of foreign directors..................................92

Table 3: Firm and merger characteristics....................................96

Table 4: The effect of foreign directors on cross-border mergers...................98

Table 5: Foreign director's impact on probability that a merger is cross-border........101

Table 6: Foreign directors and the nature of diversifying merger activity.............103

Table 7: Foreign directors and merger negotiations $\ldots \ldots \ldots \ldots \ldots \ldots \ldots \ldots \ldots \ldots \ldots \ldots \ldots$

Table 8: Foreign directors and announcement period returns $\ldots \ldots \ldots \ldots \ldots \ldots \ldots \ldots \ldots 112$

Table 9: Legal regime and accounting standards effects on CARs...................114

Table 10: Foreign director's impact on target type in cross-border mergers.............116

Table 11: The effect of foreign directors on choice of target........................ 120

Table 12: Foreign director's impact on cross-border merger price..................121

Table 13: Analysis of foreign director's impact on the method of payment in cross-border mergers............................................... 122

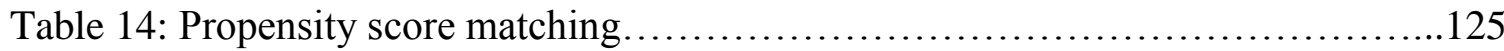

Table 15: Heckman (1979) procedure....................................... 126

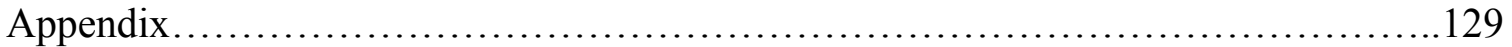




\title{
BRIDGING THE CULTURAL DIVIDE: THE ROLE OF FOREIGN DIRECTORS IN CROSS-BORDER MERGERS
}

\author{
Yaqoub Alabdullah \\ Professor Stephen Ferris, Dissertation Supervisor
}

\begin{abstract}
This study examines the influence of foreign directors on the advising role of corporate boards. I use cross-border mergers as a test of the ability of foreign directors to provide effective strategic advising. Social science literature argues that outsiders can positively influence groups by enhancing the quality of their decision-making.

I find that firms with foreign directors on their boards are more likely to engage in cross-border mergers, engage in a higher number of cross-border mergers, and put more dollars in cross-border mergers. Consistent with the fact that outsiders positively impact groups, I find that firms with foreign directors are more likely to engage in nondiversifying mergers, friendly mergers, and acquiring privately-held targets. Moreover, I find that firms with foreign directors have higher announcement-period returns, pay less for their cross-border targets, and acquire undervalued targets. I also find that firms with foreign directors are more likely to use equity in their payment for cross-border targets.

This study answers important questions regarding the effect of diversity in corporate boards. This research expands our understanding of how board diversity in the form of foreign directors can enhance board advising effectiveness. As companies seek foreign acquisitions, they face difficult legal, cultural, and informational challenges that can impede merger competition. Foreign directors play a key role in reducing these challenges and help to bridge the cultural gap between the acquirer and target.
\end{abstract}




\section{Chapter 1: INTRODUCTION}

One of the most important roles for directors on corporate boards is to advise the firm's managers (Herlamin and Weisbach, 2003). Recent literature focuses on this advising role and notes that it is crucial to the governance of the firm (e.g., Brickley and Zimmerman, 2010 and Masulis, Wang, and Xie, 2012). Since advising by the board of directors is a critical element to the governance of firms, this research focuses on that role. More specifically, I focus on a subset of directors - foreign directors, and the importance of their advising role.

I argue that foreign directors play a unique and important role in advising the managers of their firm. The literature is scarce on studies that examine how foreign directors influence board functions (e.g., Masulis, Wang, and Xie, 2012). Foreign directors come from countries with cultures and values different from that of the country where their firms are incorporated. Each board member is influenced by his culture, which in turn influences his actions, recommendations and decision-making. Moreover, cultural differences between board members can trouble the firm because it can affect the harmony and unity of the board. Despite these potential problems, foreign directors can bring value to the firm due to their business networks and knowledge of foreign commercial practices. I argue that foreign directors improve the advising ability of corporate boards.

To examine the advising effectiveness of foreign directors, I investigate their role in cross-border mergers. I focus on cross-border mergers because these mergers contain many new legal, cultural, and informational challenges for which foreign directors can 
assist. Cross-border mergers constitute a unique test of how foreign directors perform their advising role. Indeed, the literature often uses mergers to test the advising ability of boards (e.g., Masulis, Wang, and Xie, 2012 and Miletkov, Poulsen and Wintoki, 2012). Board members advise managers on this strategically important decision and ultimately have final approval of the merger. Examining how foreign directors influence these merger decisions sheds further light on how foreign board members affect board advising effectiveness.

I borrow theories from several strands of the social sciences literature to examine how outsiders affect the performance of a group. These theories come from sociology, psychology, and management and describe how group diversity influences performance, information flow, and decision-making. I apply these theories to corporate boards and specifically examine how the diversity brought by foreign directors affects a board's advising effectiveness.

I begin my theoretical development with a discussion of the homophily effect described in the sociology and psychology literatures (Shrum, Cheek and Hunter, 1988, McPherson, Smith-Lovin and Cook, 2001). Homophily refers to the tendency of people to associate with others similar to themselves. That is, individuals dislike interacting with those who lack a common culture, values, or demographics. Information-flow to homophilic groups is slow and localized to individuals within the group. Consequently, homophilic groups have fewer outsiders and reduced information-flow. I argue that foreign directors on boards can erode this homophilic effect and thus improve the information-flow to boards. 
Next, I examine the social capital literature and describe how it relates to the activities of corporate directors. Granovetter (1973, 1983, and 2005) argues that new information flows to individuals through weak rather than strong ties. That is, distant friends or acquaintances provide information to groups that close relationships might not offer. I argue that foreign directors have these 'weak-ties' with constituencies that are crucial for cross-border mergers. Foreign directors are likely to have ties that other board members lack and these ties can be crucial for cross-border mergers. Such ties might be beneficial to acquirers especially if they are with regulatory agencies, legal institutions, or the target firm itself.

I also examine the management literature on heterogeneity and whether it produces better decision-making (Earley and Mosakowski, 2000). I argue that board heterogeneity due to the presence of foreign directors can lead to better decision-making because it exposes the group to a wider range of opinions. Further, I contend that the diversity due to foreign directors can lead to enhanced information-flow because it exposes the board to different sources of information.

Group members might prioritize unity over a diversity of opinions if they view differing opinions as a hurdle to decision-making. The sociology literature identifies this phenomenon as groupthink (Janis, 1971). This literature contends that introducing outsiders to a group reduces the groupthink problem and can improve overall group effectiveness. Thus, I argue that foreign directors can reduce groupthink pressures that might exist in a board and thereby improve its ability to provide critical advising.

From these theories, I develop four sets of hypotheses that describe a foreign director's influence on cross-border mergers. My first set of hypotheses concern the 
influence of foreign directors on the general level of merger activity. That is, I examine the frequency of mergers, the type of the merger, and the nature of merger negotiations with foreign directors. Then, I discuss how foreign directors might influence the performance of a merger. My third set of hypotheses describes how foreign directors can affect the price paid for a target. Finally, I test the type of targets that firms with foreign directors attempt to acquire.

In my examination of merger activity level, I find that a foreign director's presence on boards leads to more frequent cross-border merger activity. ${ }^{1}$ I contend that cross-border acquirers face legal, cultural, and informational challenges that foreign directors are able to address, thus leading to greater cross-border merger activity. Also, I find that the presence of foreign directors leads to more non-diversifying mergers. This is consistent with the ability of foreign directors to bring new perspectives and information to the board that enhances the decision-making process.

I then examine the nature of merger negotiations and find that foreign directors lead to more friendly mergers. Foreign directors can help to bridge the cultural divide between target and acquirer, thus leading to a more friendly merger. This phenomenon is referred to as cultural affinity which is a feeling of closeness to others who share the same culture or values (Calomiris, Kahn, and Longhofer, 1994 and Hunter and Walker, 1996). Such cultural affinity can help to eliminate obstacles in merger negotiations and consequently a greater incidence of friendly mergers.

My second set of hypotheses examines the foreign director's influence on crossborder merger performance. Masulis, Wang and Xie (2012) find that the presence of

\footnotetext{
${ }^{1}$ Miletkov, Poulsen and Wintoki (2012) find similar results and argue that foreign directors bring international expertise to the acquiring firm which helps them in cross-border acquisitions.
} 
foreign directors on U.S. acquirer's boards leads to stronger cross-border mergers performance, but only when the target is from the same geographical region as the foreign director. I hypothesize that this is a broader effect, and that the inter-cultural competencies of foreign directors extends beyond that of their home region. Thus, I expect and find that firms with foreign directors to have higher cross-border acquisition announcement returns relative to firms without foreign directors. I also argue that the benefits of a foreign director are not the same for all acquirers. I contend that these benefits are affected by a country's accounting standards and the level of investor protection it offers. The benefit of having a foreign director is higher when there is ambiguity in assessing the value of the target firm. This ambiguity is higher for targets incorporated in countries where the accounting standards are lower and the protections provided to investors are weaker. While I do not find a strong support for this hypothesis, I find that a foreign director's benefit to cross-border acquirers is more pronounced when they are from a country with stronger investor protections or accounting standards.

Next, I examine the types of targets that cross-border acquirers with foreign directors might pursue. I find that acquirers with foreign directors on their boards are more likely to target privately held firms. Private targets are ambiguous to value and thus constitute a challenge when an acquirer bids for them (Capron and Shen, 2007 and Erel, Kiao and Weisbach, 2012). However, foreign directors are more likely to have information about these targets through their 'weak-ties'. Moreover, I find that acquirers with foreign directors are more likely to pursue targets that are undervalued. Again, foreign directors are more likely to have private information about potential targets through their network of 'weak-ties'. 
Finally, I examine a foreign director's impact on cross-border merger payment in terms of premium and method of payment. I find that the presence of a foreign director leads to lower payment by acquirers for their cross-border targets. A foreign director can help to increase the cultural fit between the acquirer and the target. This increase in the cultural affinity between acquirer and target can ultimately result in a lower price as negotiation obstacles are more easily resolved. Moreover, foreign directors can use their 'weak-ties' to eliminate negotiation obstacles and facilitate the merger process, ultimately resulting in a lower target price.

In terms of method of payment, I argue that the influence of foreign directors can be conflicting. Hansen (1987) contends that information asymmetry leads to more equity as a method of payment in mergers. Acquirers are reluctant to pay in cash in a high information asymmetry environment where they do not know the true value of a target. Foreign directors, however, reduce this information asymmetry and lead to a greater use of cash as a method of payment. Thus, the presence of foreign directors on an acquirer's board might lead to a greater percentage of cash in the payment package.

Foreign directors, however, might have the opposite influence on the method of payment. Managers might prefer cash instead of equity either because they think their equity is undervalued (Malmendier and Tate, 2008 and Ferris, Jayaraman, and Sabherwal, 2013) or they hesitate to give other parties a huge percentage of ownership and thereby challenge the manager in his private benefits of control (Harford, HumpheryJenner and Powell, 2012). Since foreign directors challenge managers by reducing groupthink, the presence of foreign directors on acquirer's boards might lead to a greater use of equity as merger payment. I find support for this conjecture. 
This research expands our understanding of how board diversity in the form of foreign directors can enhance board advising effectiveness. ${ }^{2}$ As companies seek foreign acquisitions, they face legal, cultural, and informational challenges that can impede merger competition. Foreign directors play a key role in reducing these challenges and help to bridge the cultural gap between the acquirer and target. Moreover, my research expands the work of Masulis, Wang and Xie (2012) who argue that foreign directors of U.S. firms have a positive effect on the advising role of corporate boards. I argue that this is a broader effect and that the inter-cultural competencies of foreign directors extend beyond that of their home region. Moreover, I contend that foreign directors have influence not just on performance, but also on other aspects on the merger process.

This research also contributes to the literature that examines the effect of diversity in corporate boards (e.g., Adams and Ferreira 2004). It adds to this literature by focusing on how diversity within a board influences a strategic decision such as a cross-border merger. This research gives a positive view on a special set of directors - foreign directors, who bring a positive effect to cross-border acquirers. I contend that foreign directors positively influence the advising ability of boards by affecting cross-border merger performance, price paid, and the types of targets involved.

Moreover, this research adds to the literature on corporate social capital and its impact on different investment decisions. Recent literature is focusing on such networks and their impact on corporate boards. ${ }^{3}$ Specifically, I add to the literature on social capital

\footnotetext{
${ }^{2}$ Adams, Hermalin, and Weisbach (2010) argue that FDs are especially beneficial for firms which plan to expand into foreign markets.

${ }^{3}$ For example, Cai and Sevilir (2012) find acquirers have higher announcement returns when the acquirer and the target share a common director on their board. Ishii and Xuan (2010) examine the effect of social ties between acquirer and target firms on merger performance. As opposed to Cai and Sevilir (2012) finding that professional connections present at the time of the acquisition announcement have a positive effect on acquirer announcement returns, they find that social ties between acquirer and target firms have a
} 
by examining how 'weak-ties' of foreign directors are critical in the merger process. The sociology literature describe such 'weak-ties' as a part of the bridging nature of social capital. The bridging view of social capital refers to networks that groups have with different groups. Adler and Kwon (2002) and Woolcock and Narayan (2000) emphasize that the bridging nature of social capital can explain differential success of individuals and firms. This research examine how 'weak-ties', which are a critical element of social capital, present opportunities for firms in the merger stage and how such networks are valuable. Such networks that foreign directors have positively influence merger negotiations, activity, and price paid.

I also contribute to the M\&A literature by focusing on how foreign directors on acquirer's board can affect a merger. Such influence in unexplored in previous literature and I argue that foreign directors play a critical role in different aspects of the merger process and performance. ${ }^{4}$ I argue that the foreign directors play a key role in crossborder merger volume, negotiations, performance, financing, and type of target pursued. I also demonstrate how foreign directors reduce some of the challenges that cross-border acquires might face when they expand overseas.

negative effect on acquirer announcement returns. Schonlau and Singh (2009) find that firms with more connected boards to other firms are more likely to undertake acquisitions as well as to be acquired. Such firms also exhibit better performance in the years after the acquisition.

${ }^{4}$ The literature on cross-border M\&A is inconclusive regarding the value of such mergers for acquirers. For example, Moeller and Schlingemann (2005), argue that cross-border mergers destroy firm value while Francis, Hasan and Sun (2008) find opposite results. 


\section{Chapter 2: THEORETICAL DISCUSSION OF THE EFFECT OF OUTSIDERS}

In this chapter, I develop a set of explanations of why outsiders on a board might influence its effectiveness. First, I explore the effect of homophily that was originally developed in the sociology literature. Homophily explains why people tend to associate with others who are similar. Such individuals suffer from an information disadvantage since the contributions provided by outsiders are limited. Next, I discuss the role of social connections and networks. I examine how social networks, especially networks of people who are only remotely connected, enhance information flow. Then, I examine the management literature on heterogeneity its effect on team performance. Finally, I analyze the literature on groupthink and describe how outsiders can offset the tendency of groups to prioritize harmony rather than critical decision-making.

\section{Homophilic effects on group effectiveness}

The homophily effect describes the tendency of people to associate with those who are similar to themselves (Shrum, Cheek and Hunter 1988, McPherson, Smith-Lovin and Cook 2001 and Ruff, Aldrich and Carter 2003). Lazarsfeld and Merton (1954) propose the term 'homophily' to refer to the tendency for persons who affiliate with each other to have similar attributes. The homophily effect asserts that contacts among individuals who are similar occur at a higher rate than among dissimilar individuals.

This tendency of people to associate with people like themselves is widely recognized in the sociology literature as a major factor in group formations. People also form relationships based on comparability of attitudes or experiences. In general, the 
probability of a relationship between two individuals increases as the two have more commonalities between them.

Lazarsfeld and Merton (1954) argue that there are two kinds of homophilic groups. First, organizations that are formed on the basis of demographic characteristics (Bott 1928, Loomis 1946) are called status homophily groups. Second, groups formed by psychological characteristics or value such as intelligence, attitudes, or aspirations (Almack 1922 and Richardson 1940) are called value homophily groups. Both kinds of homophilic groups suffer from narrow information gathering channels. Status homophilic groups limit access to the group from outsiders with different demographics. This prevents the wider information gathering that a member from a different demographic group brings to the group. Value homophilic groups lack the analysis, debate, and different views an outsider offers. An outsider can expand the set of opinions and solutions that a group might require to solve a specific problem.

McPherson, Smith-Lovin and Cook (2001) argue that the major implication of homophily is that the flow of information through groups tends to be localized. That is, the information flow in groups tends to be transmitted from person to person, which means that outside influences are minimal. External influence is limited because homophilic groups receive and process information exclusively from persons similar to themselves. Thus, the information received by homophilic groups typically originates from group members who share comparable demographics or values. Outsiders have little or no role in contributing to a homophilic group's information gathering process.

McPherson, Smith-Lovin and Cook (2001) describe the process under which groups receive information. They argue that social characteristics produce information 
gathering channels or networks. People receive information from individuals with whom they are associated. Thus, social connections serve as information channels for group members. With large differences in social characteristics, more information gathering channels are created within a group. Homophilic groups suffer from narrower information sets because their information gathering channels are determined exclusively by the demographic and value characteristics on which the group is originally constructed. Thus, when making a decision, homophilic groups lack the wider information set that other groups might have. This disadvantages homophilic groups in making an informed decision.

Homophilic groups also suffer from information isolation. Because homopilic individuals limit their networks to people similar to them, the group becomes informationally isolated. With more outsiders in a group, a greater number of perspectives, opinions, and solutions are introduced because a variety of information gathering channels are used. Moreover, homophilic groups suffer from slowness in their information gathering channels. New information is slow to reach homophilic groups because of the limited breadth of their information gathering network. This information delay puts the group at a disadvantage relative to competitors.

Groups that are not homophilic gather a wider variety of perspectives on issues because their information gathering process is expanded (McPherson, Smith-Lovin and Cook 2001). Non-homophilic groups are better integrated with the broader information environment since members from different backgrounds share varying perspectives. Outsiders in a non-homophilic group improve the quality of decision-making because their different perspectives and information are now included. 
A group such as a board of directors needs information to perform their advising role. Consequently, the channel under which the board obtains this information is crucial for effective decision-making. Homophily effects in corporate boards affect the information that they collect, how they internally process that information, and what decisions they ultimately make using that information.

\section{Social Networks}

Social networks are central to our understanding of how group membership can impact an organization's effectiveness. According to Wasserman and Katherine (1994), a social network is a social structure that connects at least two groups or individuals. Blau (1977) argues that the fundamental fact of social life is that human beings do not live in isolation and they establish associations with others through interaction and communication. People interact with others through their social networks. People associate with others and create networks to satisfy different needs. Social networks are important because they allow people to learn of opportunities, solve problems, and attain goals.

Most relevant for my analysis of how social networks influence board effectiveness is what social scientists call "weak ties". A weak tie is a relationship among individuals or groups that is distant or infrequent. For example, when two individuals meet annually at a conference and their communication throughout the year is limited, their relationship is said to be a "weak tie".

Granovetter (1973, 1983, and 2005) argues that new information flows to individuals through weak rather than strong ties. Because our close friends tend to move in the same circles as we do, the information they receive overlaps considerably with 
what we already know. More distant acquaintances, by contrast, know people that we do not and, thus, receive now information. This outcome arises in part because weak-tie individuals are different from us and their membership in other groups connects us to a wider world. These weak-tie acquaintances can therefore be better sources to obtain new information.

Erickson (2003) further explains how weak ties are critical for group success. People are more likely to succeed in their objectives if their social networks are 'well connected' and diverse at the same time. People are more likely to find opportunities and obtain new information if they are socially connected. Socially connected individuals are more likely to have different sources of information and opinions about a specific issue. Thus, weak ties are critical for individuals and groups because of the expanded opportunity and information that these ties provide.

Burt $(1992,2004)$ argues that groups characterized by dense clusters of strong connections lack the advantages of "weak tie" groups. Information within these groups tends to be redundant and stale. Since members share common views and opinions, they interpret and process information similarly. Burt (1992) argues that when two groups are connected through a "weak tie", however, new or non-redundant information travels more easily. A weak tie relationship acts as a bridge between the two groups so that nonredundant and material information travels quickly between them.

Since social connections and networks are critical for group success, boards benefit from such connections. As a group, board of directors receive, process and interpret information necessary to perform their duties. Board members need material and non-redundant information on which to make decisions. Social networks and connections 
can provide boards with the information that they need. Social connections can provide new perspective, new information, or a critical analysis that will allow a board to make a strong decision. The social connections generated from weak-ties can provide material, fresh, and non-redundant information to the board.

\section{The effect of group heterogeneity}

The literature on heterogeneity examines the impact of diversity on group performance (e.g. Bantel and Jackson, 1989; Boeker, 1997a; Wiersema and Bantel, 1992 Hambrick, Cho, and Chen, 1996). My interest in this literature focuses on why we would expect diverse groups, specifically boards with foreign directors, to perform differently from homogenous groups.

There are three streams in this literature regarding performance and diversity. First, many scholars argue for a positive association between team similarity and effectiveness. That is, teams that are similar are more effective than those which are diverse. (O’Reilly, Caldwell and Barnett 1989; Pfeffer, 1983; Tsui, Egan and O’Reilly 1992; Hambrick and Mason 1984). Researchers such as Ibarra (1992), Byrne, (1969), Lott and Lott, (1965), Luttmer (2001) and Costa and Kahn (2003) argue that homogenous teams enjoy stronger affinity and loyalty, thus their performance is better. Their improved performance stems from the fact that the loyalty and affinity within a homogenous team allows for easier communication and the quicker resolution of conflict. The language, religion, and values barriers, which according to this literature hinder communication, are minimal among homogenous groups due to a common culture (Earley and Mosakowski 2000). 
Another set of researchers, however, offers contrary results regarding diversity and performance. This literature emphasizes the importance of diversity for team effectiveness. Specifically, these researchers conclude that a variety of cultural backgrounds and demographics enhances the skills of the team (Cox 1993; Cox, Lobel and McLeod 1991; Jackson 1992; Watson, Kumar and Mickaelson 1993). This variety improves the skill set of the group, allowing it to perform more effectively across varying environments. Homogenous teams lack this skill diversity. Thus, homogenous teams are less effective and perform at lower levels because of their similarities.

Finally, research on team composition and minority influence demonstrates how a small amount of heterogeneity might enhance group effectiveness. Moscovici (1976) and Nemeth (1986) describe how a small minority influence can enhance a team's functioning. Nemeth (1986) argues that minorities improve team functioning because their viewpoints stimulate divergent attention and thought. As a result, even if they are wrong, they contribute to the identification of solutions. The presence of a minority influence enhances the decision-making process because it fosters a greater range of thought about a particular issue. These ideas would most likely have been unavailable to decision makers if they possessed similar backgrounds.

Earley and Mosakowski (2000) argue that these three different views regarding team performance and diversity imply a U-shaped relationship. They hypothesize that there is a curvilinear relationship between team heterogeneity and effective performance. Earley and Mosakowski (2000) contend that team homogeneity strengthens group performance in the short-run. That is, diverse teams might find it difficult to communicate, making diversity a short-term cost. In the long-run, however, 
heterogeneous teams will pierce the communication barrier and team diversity becomes beneficial. Heterogeneity in the long-run brings new ideas and perspectives to the group. Consequently, Earley and Mosakowski (2000) speculate that there might be an optimal level of heterogeneity among teams.

Since the literature regarding team heterogeneity and effectiveness is mixed, we are uncertain about the effect of heterogeneity on board effectiveness. Outsiders might bring new insights and information that boards need. They can enhance a board's ability to make informed decisions based on an expanded information set. They might bring new insights, arguments, and information ignored by other group members. However, diverse boards can find it difficult to communicate and share common values. Moreover, there might be physical barriers to communication if outsiders are at locations far from the firm's headquarters. These costs can hinder the board's ability to make efficient decisions. A comparison of these benefits and costs might imply an optimal level of heterogeneity among board members.

\section{The groupthink phenomenon}

Groupthink refers to the phenomenon that members of a group prioritize harmony or uniformity of decision making over the quality of the decision. Janis (1971) is the pioneer behind this theory and defines groupthink as "the mode of thinking that persons engage in when concurrence-seeking becomes so dominant in a cohesive in-group that it tends to override realistic appraisal of alternative courses of action". Group members try to minimize conflict and reach a consensus without the critical evaluation of alternative ideas or viewpoints. They tend to isolate themselves from outside influences when deciding. Loyalty to the group requires individuals to avoid raising controversial issues or 
alternative solutions, resulting in a loss of individual creativity, uniqueness, and independent thinking.

Loyalty to the group plays an important role in the presence of groupthink. It is the main driver behind a member's decision to concur with the group and not to offer different opinions or perspectives. Groups suffering from groupthink view conflict in their group as a cost rather a benefit (Myers 1999).

Janis (1972) argues that there are three main causes behind groupthink. First, he argues that organizations characterized by a high 'group cohesiveness' can suffer from groupthink. This occurs because group cohesiveness becomes more important than personal freedom of expression. This cohesiveness, in turn, causes members to emphasize group unity and view divergence in opinions to be harmful. Second, Janis believes that structural faults within groups can cause groupthink. These include insulation of the group, lack of impartial leadership, an absence of norms requiring methodological procedures, or homogeneity of members' social backgrounds and ideology. Third, Janis asserts that the situational context of the group might foster groupthink. For example, groups that face highly stressful external threats, suffer from recent failures, face excessive difficulties on the decision-making task, or face moral dilemmas are more likely to suffer from groupthink.

Janis (1982), Aldag and Fuller (1993), and Myers (1999) offer solutions to prevent groupthink. First, they contend that group members, and especially the group leader, should be impartial to alternative solutions or courses of actions. Second, groups should encourage critical evaluations and constructive feedback. Third, groups should 
subdivide and assign tasks to subgroups, and then reunite to discuss solutions. Fourth, groups should welcome critiques and solutions from outside experts and associates.

As another solution to groupthink, Hart (1991) argues that each member should discuss ideas and solutions with trusted people external to the group. The group should invite outside experts to meetings and deliberations. Group members should be allowed to question the outside experts.

All of these solutions involve external experts offering their opinions and proposing solutions. Group isolation and a negative view of outsiders can hinder the development of alternative solutions, thus leading to suboptimal decision-making. The active recruitment and use of members from outside the group can reduce groupthink.

Since the board of directors is a social group, it might suffer from groupthink. Some board members might prioritize loyalty over a full discussion and analysis of alternatives. Those members might view such debate as a reduction in board effectiveness. One possible solution to this problem is to welcome the advice of outsiders and involve them in the decision making process. Outsiders can break the cultural barriers that prevent board members from introducing new solutions. Thus, the inclusion of foreign directors on corporate boards can erode groupthink tendencies and contribute to superior decision-making. 


\section{Chapter 3: HYPOTHESES DEVELOPMENT}

In this chapter, I develop a set of hypotheses regarding the effect of foreign directors on different aspects of mergers and acquisitions. In the preceding theory section, I discuss how outsiders have a distinct influence on teams and groups. In this section, I examine how a unique set of outsiders - foreign directors exerts its influence on the firm's board of directors. More specifically, I investigate how foreign directors affect the merger and acquisition decision.

I develop a set of hypotheses based on four aspects of mergers and acquisitions activity. First, I develop hypotheses regarding the influence of foreign directors on merger activity. That is, I examine the frequency of mergers, the type of the merger, and the nature of merger negotiations of firms with foreign directors. Then, I examine merger performance and develop hypotheses based on short-run and long-run performance of the merger and what firms are most likely to benefit of such mergers. Next, I examine the form of merger payment and develop hypotheses regarding how foreign directors might affect the form and magnitude of the payment. Finally, I test the type of targets that firms with foreign directors attempt to acquire.

\section{Merger activity and foreign directors}

In this section, I develop three hypotheses concerning the frequency and nature of cross-border merger activity and how foreign directors influence it. First, I examine the likelihood that a firm pursues a cross-border merger when it has a foreign director on its board. Next, I develop a hypothesis that pertains to the role of foreign director's impact 
on the diversifying nature of a cross-border merger. Finally, I examine how foreign directors impact the friendliness of cross-border mergers.

\section{Informational, legal and cultural effects on cross-border merger frequency}

Firms face various challenges when they elect to pursue a cross-border merger. These challenges are informational (e.g., Masulis, Wang and Xie, 2012 and Faccio and Masulis, 2005), legal (e.g. Chari, Ouimet and Tesar, 2010, Martynova and Renneboog, 2008, Rossi and Volpin, 2004, and Bris and Cabolis, 2008) or cultural (e.g. Ahern, Daminelli and Fracassi, 2012, Coisne, 2011, Stahl and Voigt, 2008, Morosini, Shane and Singh, 1998, Chakrabarti, Gupta-Mukherjee and Jayaraman, 2009) in nature ${ }^{5}$. Firms face information problems when they acquire foreign targets because they are entering a new market and possess only limited knowledge about the target and its environment. Legal challenges occur due to customs and practices that are different from those of the acquirer's own country. Due to differences in culture between the acquirer's and target's employees, it might also be difficult for the merger to realize the projected operating synergies.

\subsection{Informational challenges}

Acquirers in cross-border mergers often have limited knowledge about the target firm (Faccio and Masulis, 2005). Moreover, they have little knowledge about the industry and the market in which the target operates (Erel, Liao and Weisbach, 2012 and Stahl and Voigt 2005). Moreover, the geographical distance between the two countries hinders acquirers from physically following news about the target (Erel, Liao and Weisbach,

${ }^{5}$ See Shimizu, Hitt, Vaidyanath and Pisano (2004) for extensive review on this issue. 
2012). Thus, acquirers suffer from limited information about the target and the industry when pursuing a cross-border merger.

Firms need to improve their information about the target to make better crossborder merger decisions. Outsiders are beneficial to cross-border acquirers if they can reduce this information asymmetry. If an outsider has better information regarding the target and its industry due to personal knowledge about the region or culture, then this individual can help acquirers make better acquisition decisions. Foreign directors can provide this perspective especially if they are from the same region as the target.

The sociology and psychology literature argue that outsiders bring new insights to teams and improve decision making (e.g. Earley and Mosakowski, 2000). Foreigners play a key role in this regard because they bring an international perspective to a firm's management. For example, the homophily effect suggests that the flow of material information to homophilic groups is either slow or segmented. McPherson, Smith-Lovin and Cook (2001) argue that introducing such outsiders to such groups fosters the flow of new information and thus enhances its collective decision-making.

Granovetter's (1973, 1983, 2005) ‘weak-ties’ effect can explain why foreign directors are valuable to cross-border acquirers. Foreign directors have contacts and networks that are different from the rest of the board. These contacts can provide board members with new or insightful information about potential targets. This 'weak-ties' effect is another source of value to the acquiring firm provided by foreign directors.

Outsiders can be a solution the groupthink problem. Janis (1982) argues that a lack of heterogeneity among groups increases the probability of groupthink. Thus, boards of directors lacking director diversity might be more vulnerable to groupthink. Janis 
(1982), Aldag and Fuller (1993), and Myers (1999) argue that groups should recruit outsiders and incorporate their perspectives into decision-making. Thus, the presence of foreign directors on boards can eliminate or reduce groupthink effects on corporate board decision-making.

Foreign directors might have superior information about potential targets in their own region. Indeed, Masulis, Wang and Xie (2012) find that foreign directors are beneficial when a company is pursuing a target that is from the same geographical region as the foreign director. This occurs because foreign directors often have better information regarding the markets into which the acquirer is expanding. Foreign directors can provide useful informational, legal, or cultural expertise based on their personal experiences.

\subsection{Legal challenges}

Legal challenges might hinder a firm's decision to pursue a cross-border target. For example, acquirers face a set of legal rules and practices that are typically different from its own when pursuing a target. La Porta, Lopez, Shleifer, and Vishny (1996, 1997, 1999 and 2000) argue that the degree of investor protection and the legal origins of the country where a firm is located can explain many of the differences in international business practices. The nature of investor protections available to minority shareholders might be an obstacle to a cross-border merger. For example, targets might be unwilling to accept offers from acquirers whose laws give more power to minority shareholders because they do not want to lose their private benefits of control. Indeed, the literature on crosslisting suggests that managers and owners of firms erode their private benefits of 
control when they crosslist to a stronger legal protection country (see Ferris, Kim and Noronha (2009) for an extensive review of crosslisting).

Cross-border acquirers face new legal practices in the target's country. For example, an acquirer might expand to a country which does not enforce laws protecting property rights and patents. Moreover, acquirers might face employment laws that differ from their own. These laws can be an obstacle to mergers because acquirers might be reluctant to accept or implement them. International law states that in a cross-border acquisition of $100 \%$ of a target shares, the target firm becomes bound to the laws of the country in which the acquirer is headquartered. Nevertheless, laws of the target country that pertain to employees, suppliers, or some aspects of governance might still apply. Even though a merger is economically feasible, legal challenges might impede the smooth integration after the merger of the two companies. Indeed, Rossi and Volpin (2004), and Bris and Cabolis (2008) argue that the benefit of cross-border mergers is contingent on a country's legal environment and investor protection.

Because the 'weak-tie' effect of Granovetter (1973, 1983, and 2005) asserts that distant acquaintances can be valuable in obtaining material information, foreign directors can help the firm with their legal challenges. Foreign directors might have social networks and contacts that can help acquirers reduce these legal challenges. Foreign directors can help acquirers develop connections in the judicial or legal communities. A foreign director's contacts might be more knowledgeable about the legal practices and customs in the target's country. Moreover, foreign directors understand how the legal process operates in their region, especially with respect to informal or unwritten norms of 
practice. Thus, foreign directors can be valuable to acquirers in reducing the legal challenges faced by cross-border acquirers.

\subsection{Cultural challenges}

Cultural differences between acquirers and targets are obstacles in cross-border mergers. Firms face different values, languages, or attitudes when expanding globally. These differences in culture can jeopardize merger success. Employees, managers, and resources might find it difficult to integrate following a merger because of different cultures. Indeed, the findings of Ahern, Daminelli and Fracassi (2012) regarding cultural distance suggest that culture can hinder a firms' decision to diversify globally. The difference in culture between the acquirer and the target can be a major impediment to merger completion.

Foreign directors can help bridge this cultural distance between acquirer and target. Foreign directors serve as 'interpreters' between the acquirer and the target. Foreign directors interpret the ambiguous cultural signals that may arise during the merger. Also, a foreign director can serve as an 'ambassador' for the merger transaction. Foreign directors communicate different cultural values to the parties involved in the merger. Foreign directors can explain the target's culture and thereby help to reduce fears held by either party. Also, foreign directors can represent the acquirer during negotiations and reduce tensions arising from differences in culture or business practices.

Foreign directors can reduce the cultural challenges of cross-border mergers especially if boards are homophilic. Homophilic groups dislike associations with outsiders and thus might be reluctant to transact with firms outside their country. That is because homophilic boards might tend towards a less global perspective in their business 
practices and choice of partners. Thus, we might expect firms with homophilic boards to have less cross-border M\&A activity. However, foreign directors can help to expand the otherwise narrow view of homophilic boards.

Because foreign directors can reduce the informational, legal, and cultural challenges faced by international acquirers, I hypothesize that:

H1.1: Firms with foreign directors are more likely to engage in cross-border mergers.

\section{What kind of global mergers?}

The finance literature argues that diversifying mergers are value-destroying for firms (e.g. Jensen, 1986 and Servaes, 1996). That is, the acquisition of a target from an industry different from than that of the acquirer destroys shareholder value. Dos Santos, Errunza and Miller (2008) argue that diversified cross-border mergers result in about a $24 \%$ loss in firm value. The hubris argument of Roll (1986) and the overconfidence effect of Malmendier and Tate (2008) imply that managers overestimate the synergy gains of their acquisitions and thus destroy shareholder value. One form of this value destruction is the acquisition of a target that diversifies the acquirer. Previous research suggests that managers are naïve about the outcomes from diversifying mergers or they destroy shareholder value for reasons of self-enhancements. For either reason, firms need strong boards to advise the management regarding the desirability of diversified mergers.

Foreign directors might mitigate this problem of diversifying mergers because of several considerations. They introduce alternative thinking processes to the board because they challenge existing ways of thinking. Since they are outsiders, foreign directors are less sensitive to prevailing norms. Thus, foreign director's arguments might 
be considered "out of the box". Foreign directors are also more likely to challenge the unity of opinions of the board that results from groupthink.

Groups that suffer from groupthink prioritize unity over diversity of opinions when facing challenges (Janis, 1982, Aldag and Fuller, 1993 and, and Myers 1999). Such groups lack the diversity needed to generate solution alternatives. Such a lack of diversity often leads to poor decision-making because it is based on a limited view and incomplete information. Introducing outsiders to the group provides the analytical diversity that can improve decision-making. Thus, foreign directors, as outsiders, provide the diversity of thought that might be required to challenge the pursuit of a poorly selected target.

The 'weak-tie' effect of Granovetter (1973, 1983, and 2005) argues that distant acquaintances are valuable because of the material information they possess. Foreign directors are more likely to have a set of internationally-linked 'weak ties'. These networks broaden the information base for the board and contribute to better merger decision-making. The information obtained from the foreign director's set of 'weak-ties' can help the board identify which targets are more likely to be value destroying. Consequently, I hypothesize:

H 1.2: Firms with foreign directors are more likely to engage in non-diversifying crossborder mergers.

\section{The nature of merger negotiations}

Acquirers seek to avoid merger negotiations that are hostile. Hostile mergers can be costly to the acquiring firm (Pound 1988, Servaes, 1991, Martynova, Oosting, and Renneboog, 2006, and Burkart and Panuzi 2006) ${ }^{6}$. Hostile mergers are more costly when

\footnotetext{
${ }^{6}$ Some tender offers might be viewed as more costly than hostile mergers. Indeed, Grossman and Hart (1980) show that a small percentage of shareholders might hold their shares in a tender offer and refuse to
} 
the merger is cross-border, because they often involve legal and cultural costs (Martynova, Oosting, and Renneboog 2006). Foreign directors, however, can be valuable during merger negotiations and help to eliminate obstacles associated with hostile mergers.

The 'weak-ties' networks of foreign directors can be important in the merger negotiation process. These networks might help eliminate the bidding conflicts between acquirers and targets. Foreign directors 'weak-ties' networks can reduce conflicts and subsequent bidding wars because they are familiar with both parties. These social networks can also accelerate the negotiating process and help eliminate inefficiencies that might arise because of lengthy negotiations. Further, foreign directors can reduce the cultural barriers that hinder merger negotiations by accelerating the information flow between acquirer and target.

Foreign directors can help homophilic boards with their cross-border negotiation process. By definition, homophilic groups resist the influence of outsiders. Thus, a homophilic board might resist negotiation with a cross-border target and simply undertake a hostile takeover. Foreign directors can foster merger negotiations through compromises, adjustments in the terms of the merger, or dialogue. All of these conditions are characteristics of a friendly merger.

A further advantage of foreign directors is their international knowledge about foreign markets and their expertise on how these markets operate. Indeed, Masulis, Wang and Xie (2012) and Adams, Hermalin, and Weisbach (2010) argue that foreign directors are especially beneficial for firms which plan to expand into foreign markets. They can

relinquish their control until the offer price is increases. Thus, tender offers might sometimes be more expensive for acquirers. 
advise the board on business related issues that only locals might know about. As companies expand overseas, they face legal, cultural, and informational environments that can hinder mergers. Plus, shareholders of the target firm might resist takeovers from foreign acquirers for non-business related reasons. For instance, some cultures value nationalism and can view foreign takeovers as offensive ${ }^{7}$. Thus, having foreign directors on boards might help in negotiating a deal that reduces or eliminates these obstacles to a successful merger.

The literature on team heterogeneity and minority influence suggests how having foreign directors on a board might increase its efficiency. Moscovici (1976) and Nemeth (1986) describe how a small minority influence can enhance a team's functioning. Nemeth (1986) argues that minorities improve team functioning because their viewpoints stimulate divergent attention and thought. Earley and Mosakowski (2000) argue that, in the long-run, having some outsiders is efficient for team functioning and decisionmaking. Thus, having foreign directors on boards for acquirers who try to negotiate with cross-border targets can improve the negotiating process and make it more efficient. This is because foreign directors provide cultural interpretations and insights that bridge the cultural divide between firms. Also, foreign directors can help the board design an offer that is more likely to be acceptable.

The preceding discussion shows how foreign directors can help an acquirer negotiate a better deal with its overseas target. Foreign directors help reduce the barriers to an effective negotiation process between the firms involved in the cross-border merger. Foreign directors help eliminate these barriers through the communication and

\footnotetext{
${ }^{7}$ See Ahern, Daminelli, and Fracassi (2012) for more details about cultural challenges with cross-border mergers.
} 
information exchange provided through their 'weak-ties' networks. For these reasons, I

hypothesize that:

H 1.3: Firms with foreign directors are more likely to engage in friendly mergers with their cross-border targets.

\section{Merger performance}

In this section, I develop two hypotheses that pertain to how foreign directors influence cross-border merger performance. First, I argue that acquirers benefit from having foreign directors on their boards when pursuing a cross-border target as measured by announcement period returns. Then, I explain how the value of a foreign director is mitigated by the extent of legal protections available to investors and the nature of the required accounting standards.

\section{Announcement returns}

Given that foreign directors help cross-border acquirers with the informational, legal and cultural challenges that they face, I expect firms with foreign directors to have better performance from international mergers. Although the general performance of cross-border mergers is still ambiguous ${ }^{8}$, Masulis, Wang and Xie (2012) analyze U.S firms and find that acquirers in cross-border mergers experience higher returns if they have foreign directors on their boards when the target is from the same region as the foreign director's ${ }^{9}$. They argue that foreign directors bring international knowledge to the board and thus help the firm in deal negotiation. Foreign directors help cross-border

\footnotetext{
${ }^{8}$ Much of the earlier evidence suggests that corporate international diversification increases firm value (e.g., Errunza and Senbet 1981, 1984, Kim and Lyn 1986 and Morck and Yeung 1991). However, more recent evidence finds that international diversification destroys value (e.g., Bodnar et al. 1999, Christophe 1997, and Denis et al. 2002).

${ }^{9}$ Miletkov, Poulsen and Wintoki (2012) find opposite result. They argue that foreign directors are costly and thus they hinder effective communication and performance of the board overall.
} 
acquirers through their 'weak-ties' and connections. For example, because of their 'weakties', foreign directors might be able to identify superior targets that have stronger profitability or are undervalued. Foreign directors can bridge the cultural gap between the two firms and help overcome homophilic resistance to a foreign acquirer. This process might result in a better offer price and avoid acquirer overpayment.

Since foreign directors can serve as "ambassadors" from the acquirer to the target in the merger process, they can help reduce the cultural conflicts that might arise during the merger integration. This cultural conflict is the main reason behind the failure of many mergers. Indeed, Ahern, Daminelli and Fracassi (2012), argue that culture explains why the cross-border merger volume from culturally distant countries is low relative to cultures that are closer. ${ }^{10}$ Merging firms with divergent cultures might find it difficult to integrate, with language, religion, or social values hindering the interaction between employees, managers or board members. This might result in low or negative returns from the merger. Foreign directors can help reduce these conflicts since they are often more familiar with the target's culture and business practices.

I also argue that heterogeneity among board members result in a better decisionmaking regarding cross-border mergers. Foreign directors expand the skill set of the board, allowing it to perform more effectively across varying environments. They can help in identifying targets that generate synergetic gains, making the payment and negotiation processes more efficient, or reducing conflicts during the integration process. Foreign directors can challenge the urgency to unity that often plagues boards. Foreign

\footnotetext{
${ }^{10}$ For more information regarding the cultural influences in cross-border merger, see Coisne (2011), Stahl and Voigt (2008), Morosini, Shane and Singh (1998), Chakrabarti, Gupta-Mukherjee and Jayaraman (2009).
} 
directors can introduce new ideas, opinions, or courses of actions that acquirers make in their cross-border merger decision.

Moreover, foreign directors might have information about local markets that other board members or managers lack. This information can be firm-specific, industryfocused, or market based. Indeed, the homophily effect asserts that the flow of information is facilitated by outsiders, allowing them to make better decisions. These advantages of having foreign directors on boards might be viewed as value-enhancing by investors. Thus, investors might react positively to the announcement of a cross-border acquisition by firms with foreign directors. Thus, I hypothesize:

\section{H 2.1: Firms with foreign directors have higher announcement period returns when engaging in cross-border acquisitions.}

\section{Investor protection and accounting standards effects}

In this section, I develop a hypothesis regarding which acquirers benefit more from having foreign directors on their board. Since international acquirers face legal, cultural, and informational challenges when pursuing cross-border mergers, the benefit to acquirers is contingent on the foreign director's ability to overcome these challenges. The benefit of having a foreign director might not be the same for all cross-border acquirers.

I argue that the benefit of foreign directors to acquirers is high when there is ambiguity about the valuation of the target. For targets in weak legal protection countries, managers have higher private benefits of control (Dyck and Zingales, 2004) and thus, valuation is more ambiguous. Higher private benefits of control and less investor protection is associated with more asset misallocation, less transparency, and tunneling (e.g., Shleifer and Vishny, 1997 and Dyck and Zingales, 2004) and thus, more ambiguous 
valuation $^{11}$. Information provided by foreign directors can help acquirers offer a more correct offer price. Thus, I expect cross-border acquirers to benefit from their foreign directors especially when the target is from a weak legal protection country.

Moreover, valuation ambiguity is higher when the accounting standards in the target country are weak. Investors cannot assess the true value of a company if the accounting standards do not require sufficient disclosure or the transparency requirements are weak (e.g., Holthausen, 2009). Thus, acquirers have difficulty in assessing the true value of a target if the target is from a country with weak accounting standards. Foreign directors might be more knowledgeable about their region's laws and accounting practices. This can help acquirers in their assessment of the target's true value. Also, foreign directors might have 'weak-ties' to the target's executives, employees, or auditors who have private information about the target. These connections can help acquirers gain information to better value the target. Thus, foreign directors can provide useful supplemental information to acquirers regarding targets located in countries with weak accounting standards.

Because the benefits of having foreign directors on cross-border acquirers are greater when valuation ambiguity about the target is higher, I hypothesize that:

\section{H 2.2: Acquirers with foreign directors on their boards have higher announcement period returns when the target is incorporated in countries with weak legal protection or accounting standards.}

\footnotetext{
${ }^{11}$ Bris and Cabolis (2008) and Martynova and Renneboog (2008) find that the better the shareholder protection and accounting standards in the acquirer's country, the higher the merger performance in crossborder mergers relative to domestic mergers. Also, Chari, Ouimet and Tesar (2010) find that the merger announcement returns for the acquirer is higher when the contracting environment is weak in the target's country. Starks and Wei (2013) find similar results for stock offers. They argue that acquirers compensate target shareholders for the resulting exposure to inferior corporate governance regimes.
} 


\section{Merger Targets}

In this section, I develop two hypotheses regarding how foreign directors influence an acquirer's choice of cross-border targets. First, I contend that cross-border acquirers with foreign directors are more likely to acquire private targets. Then, I argue that foreign directors are better able to identify targets that are undervalued. The basic premise of the arguments stems from the fact that foreign directors have social connections and information that might help cross-border acquirers make better decisions regarding the target.

\section{Types of targets}

Private firms are difficult to value because their financial position is not known to the public (Capron and Shen, 2007 and Erel, Kiao and Weisbach, 2012). Moeller and Schlingemann (2005) find that most cross-border acquisitions rarely involve private targets. $^{12}$ This low frequency of private acquisitions suggests that information asymmetry plays a key role when firms consider the type of target they intent to buy. If acquirers do not know the true value of the target, they cannot bid a fair price for it.

However, the M\&A literature argues that acquiring private targets is valueincreasing. Prior research, such as Chang (1998) and Fuller, Netter, and Stegemoller (2002), find that acquisitions of privately held targets are value-increasing while acquisitions of publicly-held targets are value decreasing. One reason for this increase in value is the liquidity discount due to the thin trading of the firm's equity (Fuller, Netter, and Stegemoller, 2002 and Officer, 2007) ${ }^{13}$. Capron and Shen (2007) argue that another

\footnotetext{
${ }^{12}$ Although much recent evidence suggests that most cross-border M\&A activity involves private targets. (e.g., Erel, et al. (2012).

${ }^{13}$ Chang (1998) attribute this effect to the monitoring activities by target shareholders when the payment method is equity. He finds no significant difference when the payment method is cash.
} 
reason is that less information on private targets creates more value-creating opportunities for exploiting private information.

I argue that the presence of foreign directors on acquirer's boards allows acquirers to exploit this private information. Thus, acquirers are more likely to purchase privatelyheld targets. If valuation of privately-held target is difficult, then acquirers need private information that gives them the opportunity to assess the true value of the target and make a fair offer price. Foreign directors can help acquirers obtain this information and make competitive bids for these private targets. Also, foreign directors might be better able to interpret data that is available about private firms. That is, foreign directors might be more capable of serving as "auditors" of locally prepared financial information since they are likely to be more familiar with local business practices and norms.

Foreign directors also have 'weak-ties' and connections that can help acquirers obtain additional information about privately-held targets. Foreign directors might have connections with regulatory or government agencies to which private targets submit financial information. This will allow acquirers to assess more correctly the target's true value. Also, foreign directors might have connections with the target firm itself. Therefore, foreign directors can act as a facilitator for the deal, negotiating with both the target and the acquirer.

Moreover, private firms might be better able to reach acquirers with foreign directors because of their 'weak-ties'. Ownership of private firms is concentrated so the owners might find it easier to approach an acquirer to sell their firm. The presence of foreign directors might reduce any resistance of a sale to a foreign acquirer since foreign directors can reduce the cultural divide or possible homophilic resistance to the merger. 
Given that one form of value-increasing activities that firms can make is acquiring privately-held targets and that foreign directors are likely to have more private information about these targets, I hypothesize:

H3.1 Firms with foreign directors are more likely to acquire privately-held targets.

\section{Valuation of the target}

The valuation of a publicly-held target plays a key role when acquirers bid for a target. Erel, Kiao and Weisbach (2012) argue that stock market valuations explain the volume in cross-border merger activity. Rhodes-Kropf and Viswanathan $(2004,2005)$ and Shleifer and Vishny (2003) find that stock market mis-valuations drive mergers. Overpricing the target leads to overpayment and subsequent value-destruction for the acquirer. Acquirers try to minimize the offer price to realize the full potential of synergy gains. However, managers might overpay for targets if they are overconfident about their ability to generate returns (Malmendier and Tate, 2008) or if they intent to destroy shareholder value for entrenchment purposes (Harford, Humphery-Jenner and Powell, 2012). In fact, on aggregate, Roll's (1986) hubris effect explains why most mergers have negative announcement returns and that managers overpay for targets.

I argue that foreign directors help cross-border acquirers target targets that are undervalued and thus, are good investment opportunities for the acquirer. Targets that are undervalued (mispriced) do not require overpayment relative to targets that are overvalued. Indeed, Dos Santos, Errunza and Miller (2008) find that cross-border acquisitions of "fairly-valued" targets do not lead to value destruction. However, managers of the acquiring firms might be reluctant to bid for such firms because they are 
perceived as bad investment due to their relatively low price. Foreign directors might be able to spot these "attractive" targets and recommend them to managers and boards.

Foreign directors might have information about cross-border targets that convey whether they are a good investment. This information can be obtained through the foreign director's 'weak-ties' with the target firm itself, regulatory agencies, or local industry or financial experts. Such information might prove to be crucial in valuation of the target firm and whether it is over or under valued. Acquirers can analyze this information and determine whether these undervalued targets should be pursued. Thus, the presence of foreign directors might lead to more cross-border acquisitions of undervalued targets.

Since diversity among teams enhances the decision-making ability of teams, the presence of foreign directors on boards might lead to bidding for targets that are undervalued. If targeting undervalued targets is value-enhancing for the acquirer, then acquirers should search for such targets. The presence of foreign directors might help acquirers identify those targets that constitute a "good" investment for the firm. The literature on diversity (e.g., Earley and Mosakowski, 2000) argues that, in the long-run, diverse teams are better decision-makers. I argue that foreign directors help acquirers find these "good" investments and capitalize on this mispricing through their private information.

Because mispricing leads to an attractive investment opportunity for acquirers, and that the presence of foreign directors improves decision-making for firms, I hypothesize that:

\section{H3.2: Firms with foreign directors are more likely to acquire targets that are undervalued.}




\section{Merger Payment}

In this section, I develop two hypotheses with regards to foreign director's influence on the method of payment for cross-border mergers. I examine whether crossborder acquirers with foreign directors over or under pay for their targets. I argue that the presence of foreign directors leads to lower merger premiums relative to similar mergers. Thus, acquirers benefit from foreign directors since they lower the payment that targets receive from the merger. Next, I examine the foreign director's influence on the design of the payment package. Specifically, I test whether the presence of foreign directors leads to a greater use of cash or equity as payment for cross-border mergers.

\section{Merger Premium}

Overpayment for targets can be a form of value-destruction that managers might pursue during their tenure (Harford, Humphery-Jenner and Powell, 2012). Rossi and Volpin (2004) find that acquirers in cross-border mergers overpay for their targets. That is, acquirers pay higher premiums when pursuing international targets. ${ }^{14}$ Paying higher premium is often associated with loss in shareholder value (Baker, Pan, and Wurgler, $2012)^{15}$

I contend that foreign directors help cross-border acquirers negotiate a better deal that results in a lower offer price. Baker, Pan, and Wurgler (2012) argue that, during merger negotiations, the negotiating parties usually use a target's stock price as a reference point for the offer price. They argue that the offer price is biased towards recent

\footnotetext{
${ }^{14}$ Rossi and Volpin (2004) find that this result is contingent on the country's legal protection. A higher legal protection for targets leads to more premium paid by acquirers. They attribute this finding to lower cost of capital and thus, high competition by bidders for targets.

${ }^{15}$ Moeller et al. (2005) do not find evidence that high premium leads to negative shareholder's gain. However, they attribute this result to noisy premium data.
} 
peak prices and thus, result in higher premiums. Foreign directors can act as merger facilitators and reduce the conflicts that might arise over the course of the negotiations.

Foreign directors might also help cross-border acquirers negotiate a better offer price because of their 'weak-ties'. Foreign directors might have connections in their home country or region that can provide them with contacts to the target firm or its employees. These contacts can be crucial during merger negotiations and thus, enable the acquirer to build relations with the target prior to merger completion. Foreign directors might be able to negotiate an offer price that does not require revisions by the target because of their previous associations with the target.

Foreign directors might also be able to negotiate a better offer price because of their ability to reduce the homophily effect. An acquirer that is homophilic might not pursue an international target while a homophilic target might resist a foreign acquisition. Homophily effects within a target might produce a higher offer price if the target resists a foreign acquisition. Foreign directors can also act as ambassadors between the two parties involve in the merger, reducing the adverse consequences resulting from homophily and cultural distance. This ultimately results in a better price.

Moreover, foreign directors might have local information that can allow acquirers to make a better offer price. Masulis et al. (2012) argue that foreign directors are beneficial because their local expertise helps acquirers make superior cross-border merger decisions. Foreign directors might possess information about the true value of the target that is not available to other board members or managers. This information will be even more valuable when targets are located in countries with poor accounting and transparency standards. 
Since foreign directors can help negotiate a better deal with cross-border targets and might have private information about those targets, I hypothesize that:

\section{H4.1: Firms with foreign directors are more likely to pay less for their cross-border targets.}

\section{Method of payment}

There are several factors that determine the method of payment in a merger ${ }^{16}$. Bidders face a tradeoff between financial distress and corporate control considerations when deciding to finance an acquisition with cash or equity (Faccio and Masulis, 2005). Financing an acquisition with cash put acquirers at the risk of default, as more cash means higher debt financing for the merger. Alternatively, financing an acquisition with equity alters the ownership structure for the acquiring firm since a block of ownership is transferred to the target firm (Shleifer and Vishny, 2003) ${ }^{17}$. Moreover, financing an acquisition with equity might signal to shareholders that the bidder's stock price is overvalued (e.g., Travlos, 1987 and Chang, 1998).

I develop two competing hypotheses regarding the role of foreign directors and the choice of merger payment. First, using Hansen's (1987) model, I argue that information asymmetry plays a role on the financing decision. Second, I argue that foreign director's influence on the method of payment is correlated with the extent of the manager's entrenchment or perceptions regarding the pricing of the firm's equity.

\footnotetext{
${ }^{16}$ See Hansen (1987), Stultz (1988), and Fishman (1989) for a theoretical foundation of the method of payment decision in M\&A.

${ }^{17}$ The corporate control consideration is more severe when the bidder ownership concentration is large, thus allowing a blockholder with a significant amount of equity when the merger is financed with equity. Indeed, Amihud, Lev, and Travos (1990), Martin (1996), and Ghosh and Ruland (1996) conclude that buyer management shareholdings have a negative effect on stock financing.
} 
A higher degree of information asymmetry between the acquirer and target induce acquirers to issue equity to finance the merger. Hansen (1987) argues that since managers of the acquiring firm do not know the true value of the target, they prefer to finance the merger with stock. That is, acquirers will not experience any cash outflows because of the merger, so they prefer equity financing when the valuation of the target is ambiguous ${ }^{18}$.

Officer, Poulsen, and Stegemoller (2009) argue that information asymmetry leads to the use of stock as a method of payment because it helps a publicly traded acquirer share the risk of a target's overvaluation with the target's owners. Conversely, when the acquirer pays with cash, the acquirer bears all of the overvaluation risk. They find that stock-financed acquisitions have a positive announcement returns for privately held targets which are hard to value and thus, have higher degree of information asymmetry ${ }^{19}$.

I argue that foreign directors can reduce the information asymmetry regarding the target's value. Therefore, firm with foreign directors use more cash to acquire difficultto-value targets. Because of their 'weak-ties' and other information connections, foreign directors are better able to obtain new information about the target. This can make the acquirer less inclined to use equity in the offer. Therefore, I hypothesize:

\section{H4.2a: Firms with foreign directors are more likely to use cash in their payment for cross-border mergers.}

Managers might prefer cash for two reasons. Harford, Humphery-Jenner and Powell (2012) argue that entrenched managers use cash instead of equity because they do not want to create new equity blockholders. Such blockholders have an incentive to monitor managers and can reduce the private benefits of control enjoyed by managers.

\footnotetext{
${ }^{18}$ Especially if the corporate control consideration is low (as in the case with highly diffuse ownership), equity financing is viewed as more preferable to cash (Faccio and Masulis, 2005).

${ }^{19}$ Chang (1998) find similar results and attribute the positive announcement returns to value-enhancing monitoring activity by the new blockholders.
} 
Moreover, some managers might prefer cash over equity because they think that their equity is undervalued. Thus, these managers are reluctant to use their stock as a method of payment in mergers.

Thus, I expect that foreign directors are more likely to challenge the decisions reached by managers if they use cash as a method of payment when they should use equity. These managers use cash for entrenchment purposes because they do not want to create new equity blockholders or they believe that their equity is undervalued. If those managers prefer to use cash when they should use more equity, I expect that foreign directors will challenge that decision. Consequently, I hypothesize that:

H4.2b: Firms with foreign directors are more likely to use equity in their cross-border merger payment package. 


\section{Chapter 4: DATA SOURCES AND SAMPLE CONSTRUCTION}

I use four different datasets to test my hypotheses. First, I use the BoardEx dataset to obtain information concerning director demographics. Then, I use the SDC Platinum M\&A database to obtain merger information. Finally, I gather accounting and stock price information from the WorldScope and Datastream databases respectively.

BoardEx covers different aspects of governance for firms worldwide. It contains biographical information on 510,100 directors and managers for the firms in the dataset. BoardEx covers 18,733 firms worldwide from 1999 to 2012. For each director in the dataset, I obtain the director's unique identification number assigned by BoardEx, nationality, date of birth, employment information, and the start/end dates for each firm on whose boards they sit. Furthermore, for each firm in the dataset, I obtain the International Securities Identification Number (ISIN). I use ISIN to allow merging with the other datasets. I delete firms that lack an ISIN since I cannot obtain merger or accounting information for those firms ${ }^{20}$. My final sample from BoardEx covers 12,926 firms with 129,873 different directors.

I define a director to be a foreign director if his/her nationality is different from the country of incorporation of the firm on whose board they sit. Throughout the analysis, I use different measures to capture the presence of a foreign director. I examine whether a firm has a foreign director in a particular year, the number (percentage) of foreign directors on a firm's board, and a measure that incorporates the foreign director's role on

\footnotetext{
${ }^{20}$ Most of those deleted firms are privately held firms. Private firms do not have an ISIN so my final sample does not include private acquirers.
} 
the board. For example, I incorporate in my analyses whether the foreign director is independent.

To obtain merger information for my sample firms, I use the SDC platinum M\&A database. However, SDC does not have an ISIN identifier for the firms in its database. I use WorldScope (which uses ISIN as an identifier) to retrieve the Sedol codes for the firms in my sample ${ }^{21}$. Then, I use those Sedol codes as my identifier to retrieve firm data from SDC.

I obtain merger information from the SDC database for the period, 1995 to 2012. I follow Erel, Kiao and Weisbach (2012) procedure in retrieving data from the SDC database $^{22}$. I exclude LBOs, spinoffs, recapitalizations, self-tender offers, exchange offers, repurchases, partial equity stake purchases, acquisitions of remaining interest, and privatizations, as well as deals in which the target or the acquirer is a government agency. I collect a number of data items from SDC, including the announcement date, the target's name, public status, primary industry measured by the four-digit Standard Industrial Classification code, country of domicile, as well as the acquirer's name, public status, primary industry, and country of domicile. I collect the deal value in dollar terms when available, the fraction of the target firms owned by the acquirer after the acquisition, as well as other deal characteristics such as the method of payment made by the acquirer. I exclude deals in which the deal value is less than one million dollars. Of the 12,926 firms in my sample, 8,093 firms have at least one merger transaction from 1995 to 2012.

${ }^{21}$ Sedol stands for Stock Exchange Daily Official list.

${ }^{22}$ This procedure is commonly used in M\&A literature. 
I obtain accounting and financial information for the firms in my sample from WorldScope ${ }^{23}$. For ach firm, I obtain values for total assets, book value of equity, common shares outstanding, market capitalization, total debt, cash and short-term investments, foreign assets as a percentage of total assets, foreign sales as a percentage of total sales, and return on assets (ROA). I convert all variables to U.S. dollars according to WorldScope conversion rate for a given year. I obtain the same variables for the target firms using their Sedol $\operatorname{codes}^{24}$. I delete a firm-year observation if the total assets variable is missing. I use the director's start-date and end-dates on each board to generate board size, foreign director measures, and other director measures for each year in my firm-year sample. I use DataStream to obtain stock price and return information for each of the sample acquirer firms. I obtain stock prices and returns from 1993 to 2012.

${ }^{23}$ I go back two years from 1995 to obtain control measures which I use the lag variables for.

${ }^{24}$ Some of the variables are not available for the target firms because they are privately-held targets. 


\section{Chapter 5: DESCRIPTIVE STATISTICS}

Tables 1,2, and 3 present descriptive statistics for my sample. Table 1 shows the distribution of sample firms and foreign directors. The unit of observation is firm-year. Panel A of Table 1 shows the annual number of sample firms with no foreign directors, one foreign director, and multiple foreign directors. I have a total of 163,465 firm-year observations in my sample. The percentage of firms with at least one-foreign director is $26.44 \%$. This percentage ranges from 20 to 30 percent. There is a slight increasing trend of having foreign directors on boards during the first half of my sample period and a relatively low decreasing trend in the latter half of the sample.

Panel B of Table 1 shows the country distribution of firms in my sample. There is some variability across countries in the frequency of having foreign directors sit on their corporate boards. For example, the United States has $10.78 \%$ of their firm-year observations with one foreign director and $3.27 \%$ of their firm-years with multiple foreign directors. Germany, however, has $20.44 \%$ and $24.7 \%$ of their firm-years with one-foreign director and multiple foreign directors respectively. Civil law countries have a higher percentage of their firm-year observations with foreign directors than common law countries. The difference is statically significant.

Panel $\mathrm{C}$ of Table 1 describes the industry distribution of foreign directors. The industry definitions come from BoardEx. There is no noticeable concentration of foreign directors in any particular industry. The percentage of foreign directors in an industry is fairly evenly distributed among the industries. The food, drug retailors, and processors 
industry has the largest percentage of foreign directors in my sample. Utilities industry, however, has the lowest percentage.

Table 2 presents the profile statistics of foreign directors. Panel A shows the distribution of foreign director's nationalities as described in the BoardEx database. The unit of observation is director-year. American foreign directors constitute more than $22 \%$ of foreign directors in my sample, while British foreign directors constitute more than $17 \%$. French and German foreign directors constitute more than 7\% of director-years each. This panel implies that most of the foreign-directors in my sample come from developed economies.

Panel B of Table 2 shows the foreign director's roles on boards. The unit of observation is director-firm-year. Approximately $15 \%$ of the sample foreign directors are Chairmen of the board and around 15\% are CEOs. About 8\% hold Chairman and CEO position. $12.15 \%$ of the sample consists of independent foreign directors.

Panel C of Table 2 contains the number of foreign directors on a firm's board. Most of the observations indicate no foreign directors as in Table 1. Most firms who have foreign directors have only one foreign director. Only 3.6\% of firm-year observations have more than three foreign directors on their board. Panel D of Table 2 shows the incidence of multiple boarding by foreign directors. Less than $19 \%$ of director-firm-years serve on multiple boards.

Table 3 presents comparative analyses for key variables for firms with and without foreign directors. Panels A compares the means between firms with no foreign directors and firms with one foreign director. Panels B compares the means between firms with no foreign directors and firms with multiple foreign directors. Firms with 
foreign directors are significantly larger than firms with no foreign directors in terms of total assets and market value of equity. There is no significant difference between firms with and without foreign directors in terms of leverage as measured by debt scaled by total assets. Firms with multiple foreign directors have significantly higher ROA than firms with no foreign directors. There is no statistically significant difference between firms in terms of foreign assets or foreign sales as scaled by total assets and total sales respectively.

Firms with foreign directors have a larger board than those with no foreign directors. Moreover, firms with foreign directors are more likely to have less independent boards. There is no significant difference between firms with foreign directors and those with no foreign directors in terms of Tobin's Q. In general, firms with foreign directors are larger, more profitable, and have larger boards.

Panels $\mathrm{C}$ and $\mathrm{D}$ compare various aspects of M\&A activity between firms with no foreign directors and those with one or multiple foreign directors. Firms with foreign directors are more likely to engage in mergers and cross-border mergers. The variables merger and cross-border merger are binary variables which assume the value of one if a firm pursues a merger or a cross-border merger in a particular year, respectively.

This univariate analysis shows that firms are more likely to pay with cash for their targets. The table also demonstrates that acquirers with foreign directors actually pay less for their targets as measured by purchase price. Purchase price is measured as the transaction value scaled by total assets. Moreover, this analyses shows that firms with foreign directors are less likely to acquire privately-held targets and more likely to pursue diversifying mergers. 


\section{Chapter 6: EMPIRICAL ANALYSIS AND RESULTS}

\section{Cross-border merger activity}

1. The effect of foreign directors on the incidences of cross-border mergers (H1.1)

In this section, I empirically test my first set of hypotheses. First, I test my hypotheses with regards to merger activity. H1.1 predicts that firms with foreign directors are more likely to engage in cross-border mergers. I empirically test this hypothesis in Tables 4 and 5. Specifically, I use three tests to test this hypothesis. First, I examine the number of cross-border mergers that my sample firms undertake. I use a Poisson model to examine how foreign directors affect the number of cross-border mergers a firm executes in a given year. I use the following Poisson regression analysis:

$$
\log (\text { Num_CrossBorder })_{i, t}=\alpha_{0}+\beta_{1}(F D)_{i, t}+\sum_{x=1}^{j} \gamma_{x} Z_{i, t}+e_{i, t}
$$

Where Num_CrossBorder is the number of cross-border mergers a firm commits to in a particular year, $\mathrm{FD}$ is a foreign director measure, and $\mathrm{Z}_{\mathrm{i}, \mathrm{t}}$ represents a set of control variables. In panel A of Table 4, Num_CrossBorder assumes the value of zero when the firm commits to a domestic merger or does not commit to a domestic or crossborder merger ${ }^{25}$. The unit of observation is firm-year.

Panel A of Table 4 shows the results of equation (1). All regressions use year fixed effects with clustered standard errors at the country level similar to Miletkov, Poulsen and Wintoki (2012). All the control variables are lagged by one year. In model (1), I use FD variable which is a dummy variable which assumes the value of one if a firm has a least one foreign director in a given year and zero otherwise. The coefficient is

\footnotetext{
${ }^{25}$ In Table 5, I restrict the analysis to just firms who commit to a merger, either domestic or cross-border.
} 
significantly positive. The presence of foreign directors on a firm's board leads to an increase in the log of the number of cross-border mergers by a firm in a given year or about two cross-border mergers annually.

The presence of a foreign director on a board might take time to influence corporate decision-making. For this reason, I use the first and second lag of FD variable in models (2) and (3). The results remain highly significant. Moreover, I use the number of foreign directors as an independent variable with the results presented in model (4) of panel A. An increase in the number of foreign directors by one leads to an increase of about 1.15 cross-border mergers in a given year. I also use the percentage of foreign directors on a firm's board and obtain similar results.

Masulis, Wang and Xie (2012) and Miletkov, Poulsen and Wintoki (2012) argue that the benefits of foreign directors are more pronounced when the foreign director is independent. That is, the benefits of foreign directors might be higher if the director is not affiliated with the acquirer firm. I repeat my estimation of equation (1) using FID, which assumes the value of one if the firm has at least one foreign independent director and zero otherwise. The results are shown in model (6) of Panel A of Table 4. The results are similar in magnitude to previous models.

Next, I examine the volume of cross-border mergers committed by firms with foreign directors. I estimate the following Ordinary Least Squares regression:

CrooBorder_Volume $_{i, t}=\alpha_{0}+\beta_{1}(F D)_{i, t}+\sum_{x=1}^{j} \gamma_{x} Z_{i, t}+e_{i, t}$ 
Where CrossBorder_Volume is the dollar volume of cross-border mergers a firm commits to in a given year. All models use year fixed effects with clustered standard errors at the country level. Panel B of Table 4 contains the results.

The results support H1.1. The presence of foreign directors leads to an increase of about $\$ 83$ million committed to cross-border mergers. My various measures of the presence of foreign directors generally lead to the same conclusion.

In another direct test of H1.1, I use a logit model to examine the impact of having a foreign director on the likelihood of pursuing a cross-border merger. Specifically, I use the following logistic model:

$\operatorname{Pr}(\text { CrossBorder }=1 \mid X)_{i, t}=$ Logit $\left[\alpha_{0}+\beta_{1}(F D)_{i, t}+\sum_{x=1}^{j} \gamma_{x} Z_{i, t}+e_{i, t}\right]$

The results are reported in panel $\mathrm{C}$ of Table 4 . The results are statistically and economically significant. The presence of foreign directors leads to an increase of 87 percent in the odds that a firm pursues a cross-border merger. All different specifications of the benefits of foreign directors lead to the same conclusion in support of H1.1.

As a robustness test of the previous table in support of H1.1, I restrict the sample to only firms that commit to a merger in a particular year, either domestic or crossborder. I repeat my logistic analysis on this restricted sample in Table (5). The first five models use the same specifications of foreign directors as in panel C of Table 4. The results are economically and statistically significant. In model 6, I estimate equation (3) using FD_SameRegion variable which assumes the value of one if the foreign director is from the same region as the target firm. The regions are defined in Table 2. Masulis, Wang and Xie (2012) argue that the benefits of foreign directors in cross-border mergers 
are more pronounced when the director is from the same region the target firm. Model (6) of Table 5 supports this argument. The presence of foreign directors from the same region as the target firm increases the odds of that merger by 80 percent.

Moreover, I re-examine equation (3) when the foreign director is a Chairman or CEO in the firm they are board members on. Models (7) and (8) of Table 5 report these results. The results are economically and statistically significant. The presence of a foreign chairman or a foreign CEO board member raises the odds of a cross border merger by 13 and 19 percent respectively.

I incorporate cultural distance between the country of the foreign director and the country of the target firm in my analysis of equation (4). I construct a cultural distance measure (CD) that incorporate the cultural distance between the country of the target firm and the country of the foreign director. I follow Chakrabarti, Gupta-Mukherjee and Jayaraman (2009) who use Hofstede's cultural dimensions to calculate this measure. The distances are calculated from the numerical values of the four Hofstede dimensions, namely, Individualism (IDV), Uncertainty Avoidance Index (UAI), Power Distance Index (PDI) and Masculinity (MAS). The measure is computed as follows:

$$
\mathrm{CD}=\frac{\sqrt{\sum_{J=1}^{4}\left(S_{T, J}-S_{F, J}\right)^{2}}}{4}
$$

Where $S_{A, J}$ is the cultural dimension score of the country of the target firm firm and $S_{F, J}$ is the cultural dimension score for the country of the foreign director. I argue that the likelihood of a cross-border merger is higher when the cultural distance between the target and the foreign director is low. The target firm might not resist an acquisition when they can more easily relate to the culture of the acquiring firm. 
The results of my analysis of cultural distance are reported in model (9) of Table 5. The variable of interest is the interaction effect of FD*CD. I argue that the higher the cultural distance between the target firm and the foreign director, the less likely a crossborder merger will take place. The sign of the FD*CD coefficient is statistically negative, implying that a higher cultural distance between the foreign director and the target firm, makes a cross-border merger less likely to occur.

In general, Tables 4 and 5 offer strong support for H1.1. Firms with foreign directors are more likely to engage in cross-border mergers. The presence of foreign directors leads to a higher number of cross-border mergers in a given year, more dollars spent on cross-border mergers, and a greater likelihood that a cross-border merger will occur.

2. Foreign directors and the nature of diversifying merger activity (H1.2)

I argue in H1.2 that firms with foreign directors are more likely to engage in nondiversifying cross-border merger activity. I argue that the presence of foreign directors lead to better decisions regarding cross-border acquisitions. One of these decisions is acquiring cross-border targets from the same line of business, since diversifying mergers have been shown to be value destructive. I test this hypothesis in Table 6 .

My univariate analysis is presented in panel A of Table 6. I define a cross-border merger to be diversifying if the SIC of the acquirer and target differ at the one-digit level. Diversifying cross-border merger is a binary variable which assumes the value of one if the cross-border merger is a diversifying merger and zero otherwise. The Number of diversified mergers is the number of diversified cross-border mergers a firm in my 
sample commits to in a given year. Volume of diversified mergers is the dollar amount spent on diversified mergers by a firm in a given year.

Panel A of Table 6 presents a univariate test of H1.2. Firms with foreign directors are more likely to engage in non-diversifying mergers. However, firms with foreign directors commit to a higher number of diversifying cross-border mergers and invest more dollars in cross-border diversifying mergers in a given year. Thus, this univariate analysis only partially supports $H 1.2$.

I further test $H 1.2$ with multivariate analysis. First, I test the hypothesis with the following logit model:

$\operatorname{Pr}(\text { Diversifying CrossBorder }=1 \mid X)_{i, t}=$ Logit $\left[\alpha_{0}+\beta_{1}(F D)_{i, t}+\sum_{x=1}^{j} \gamma_{x} Z_{i, t}+e_{i, t}\right]$

Panel B of Table 6 reports the results. Model (1) shows that the coefficient of FD is negative and significant at the 5\% level. The presence of a foreign director on a firm's board decreases the odds of pursuing a diversifying cross-border merger by 9.7 percent. The first and second lags of the FD measure show similar significantly negative coefficients. The coefficients for the number of foreign directors and the percentage of foreign directors are not statistically significant. The coefficient of the independent foreign director, however, is significantly negative.

In the next multivariate analysis, I test the impact of foreign directors on the number of diversifying cross-border mergers an acquirer commits to in a year. I use a Poisson model and include the number of diversified cross-border mergers as my dependent variable in the following way:

Log(Num_Diversifying_CrossBorder $)_{i, t}=\alpha_{0}+\beta_{1}(F D)_{i, t}+\sum_{x=1}^{j} \gamma_{x} Z_{i, t}+e_{i, t}$ 
Panel C of Table 6 reports the results. In model (1), the coefficient for FD variable is negative and significant at the $1 \%$ level. I obtain similar results with the first and second lag of FD. The number of foreign directors and the percentage of foreign directors on a firm's board show significantly positive coefficients, in contradiction to H1.2, while the FID coefficient is insignificant. These results might stem from the decreasing benefits to outsiders as their number increase (Earley and Mosakowski, 2000).

In further analysis, I regress the dollar volume of diversifying cross-border mergers in a given year against my foreign director measures. The results are reported in Panel D of Table 6. The coefficients for the foreign director measures are statistically insignificant. This result might stem from the fact the firms with foreign directors put more dollars in cross-border mergers in the first place, as reported in Tables 4 and 5.

In general, the results from Table 6 support H1.2. Firms with foreign directors are more likely to engage in non-diversifying cross-border mergers. The results from the logit model strongly support the hypothesis, while the results from the Poisson model partially support the hypothesis.

\section{Foreign directors and the nature of merger negotiations (H1.3)}

In this section, I test $H 1.3$ which examines the friendliness of cross-border mergers when acquirers have foreign directors. Specifically, $H 1.3$ argues that firms with foreign directors are more likely to engage in friendly mergers with their cross-border targets. The SDC database identifies merger negotiations between acquirer and targets as being friendly, hostile, neutral, unsolicited, or not applicable. I delete the neutral, unsolicited, and not applicable mergers, which are 5.79 percent of the sample, to focus exclusively on the friendly/hostile difference. 
I report the results in Table 7. I use the same procedures and models as in Table 6. I test the hypothesis by modeling logit, Poisson, and OLS regressions. In the logit model, I introduce a binary variable that equals to one if the deal is friendly and zero otherwise. For the Poisson model, I calculate the number of cross-border friendly mergers that a firm commits to in a given year and add this as a new predictor. For the OLS regression, I calculate the dollar volume that a firm undertakes in a given year of friendly cross-border mergers and include this as a new independent variable.

Panel A of Table 7 shows the results of my initial univariate analysis. The percentage of mergers classified as friendly does not support $H 1.3$, while the number of friendly-cross border mergers and the volume of friendly cross-border mergers support the hypothesis. All differences are statistically significant. Firms with foreign directors commit a larger number of cross-border mergers than firms with no foreign directors. Also, firms with foreign directors put more dollars in friendly mergers than firms with no foreign directors.

Panels B, C and D report the results of the logit, Poisson and OLS models respectively. The coefficients for the foreign director measures are not statistically significant for the logit model. However, the results are statistically significant for some measures of the Poisson and OLS regressions. The insignificant results of the logit model might stem from the fact that $93.7 \%$ of my sample consists of friendly deals.

To address this unbalanced sample in the logit model, I re-estimate the logit model with a matched sample. For every hostile deal in the sample, I match it with a friendly deal that with common characteristics. Specifically, in the matched sample, I require that the acquirers share the same country and industry. I then choose one acquirer 
which is closest in total assets size to the corresponding acquirer from the hostile deal sample.

The results of the logit model of this matched sample are reported in panel E of Table 7. The coefficients for FD, FD lagged one and two years, the number of foreign directors and the percentage of foreign directors are all positive. The coefficient for FD and the one period lagged FD are statistically significant. Only the coefficient of FID is negative and significant. Foreign independent directors might not increase the likelihood of a friendly merger because they do not oversee the daily aspects of the negotiations of the merger. I argue in the hypothesis that foreign directors increase the likelihood of a friendly merger because of their involvement in merger negotiation. This involvement is reduced for directors who do not operate daily in the firm. Thus I conclude that the presence of a foreign director on an acquirer's board increases the likelihood that the cross-border merger will be friendly.

In general, my results support $H 1.3$. Firms with foreign directors commit to a higher number of friendly cross-border mergers in a given year, and put more dollars in those friendly mergers. The results of a matched sample between hostile and friendly deals provide further confirmation that the likelihood of a friendly cross-border merger is greater for acquirers with foreign directors.

\section{Cumulative abnormal returns (CARs)}

\section{CARs and foreign directors (H2.1)}

In this section, I test H2.1. I argue in this hypothesis that acquirers with foreign directors on their boards enjoy higher announcement period abnormal returns. This higher return stems from the fact that foreign directors are better able to direct acquirers 
towards targets that have greater synergy potential. Consequently, acquirers with foreign directors experience higher cumulative abnormal returns (CARs) as a result of their cross-border announcement.

I measure the market impact of each acquisition by calculating buy-and-hold cumulative abnormal returns. I first estimate the market model regression of dollar dominated daily returns on the corresponding dollar dominated market return. For each acquirer, I use the returns of the major equity index in the acquirer's country of incorporation as the market return. Data on the returns to the indices are available from DataStream. For acquirers that lack a corresponding market index available in DataStream, I use the MSCI world index as their market index (these countries include Argentina, Belgium, Chile, China, Colombia, Croatia, Czech Republic, Hungary, India, Indonesia, Israel, Slovenia, South Korea, Turkey, and United Arab Emirates) . I calculate the CARs for a window around the announcement date of the cross-border merger. The market model regressions are performed in the following way:

$$
R_{i j t}=\alpha_{i}+\beta_{i}^{m} R_{m j t}+\varepsilon_{i t}
$$

Where $\mathrm{t}=-131, \ldots,-31$ and $R_{i j t}$ refers to the daily stock return for the acquiring firm $i$ in country $j$ and $R_{m j t}$ is the market return in country $j$. I require that each firm has at least fifty non-missing return data in this estimation period. The residual $\varepsilon_{i t}$ defines the excess return for firm $i$ and day $t$.

I then compute the abnormal returns and accumulate them over five different subperiods: $(-1,+1),(-2,+2),(0,+1),(-5,+5)$, and $(0,+10)$. The CAR in period $\left(\mathrm{T}_{1}, \mathrm{~T}_{2}\right)$ for firm $i$ is computed as: 


$$
C A R_{i}^{(\mathrm{T} 1, \mathrm{~T} 2)}=\prod_{t=T_{1}}^{t=T_{2}}\left(1+\hat{\varepsilon}_{i t}\right)-1
$$

Panel A of Table 8 reports the averages of these estimation windows for firms with and without foreign directors. There is no statistically significant difference in CARs for firms with and without foreign directors in the windows $(-1,+1),(-2,+2)$, and $(0,+1)$. However, the longer windows $(-5,+5)$ and $(0,+10)$ show that firms with foreign directors generate higher CARs surrounding the cross-border merger announcement date. The difference is statistically significant and is consistent with $H 2.1$. Firms with foreign directors generate an average of 60 additional basis points of return compared to firms with no foreign directors surrounding the announcement of their cross-border merger.

In my corresponding multivariate analysis, I estimate the following OLS regression model:

$$
C A R_{i, t}^{(-2,+2)}=\alpha_{0}+\beta_{1}(F D)_{i, t}+\sum_{x=1}^{j} \gamma_{x} Z_{i, t}+e_{i, t}
$$

Panel B of Table 8 contains the empirical results. The variables FD, the first and second lag of FD, and the percentage of FD on boards show positive and significant coefficients. Firms with foreign directors generate 59 basis points higher CARs than firms with no foreign directors ${ }^{26}$. Only the number of foreign directors and the FID measure exhibit insignificant coefficients.

In general, the results of Table 8 support H2.1. Firms with foreign directors have higher announcement period abnormal returns than firms with no foreign directors.

\footnotetext{
${ }^{26}$ In unreported results, I estimate equation (9) using other windows. My strongest results occur in the (-2, $+2)$ window. In the M\&A literature, it is common to use the $(-2,+2)$ window. Examples include Masulis, Wang, and Xie (2012), Bris and Cabolis (2008), Erel, Liao and Weisbach (2012), and Moeller and Schlingemann (2005).
} 
Investors welcome cross-border mergers announced by acquirers with foreign directors. This higher return stems from the fact that foreign directors are better able to direct acquirers towards targets that have greater synergy potential. Consequently, acquirers with foreign directors experience higher cumulative abnormal returns (CARs) as a result of their cross-border announcement.

\section{Foreign directors, investor protection and accounting standards (H2.2)}

I argue in $H 2.2$ that acquirers with foreign directors on their boards have higher announcement period returns when the target is incorporated in countries with weak legal protections for investors or lower accounting standards. I argue that foreign directors can provide more benefit to acquirers when there is ambiguity in a target's valuation. This ambiguity is more pronounced when the target is incorporated in countries with weak investor protection or accounting standards. Less investor protection and weak accounting standards are associated with more asset misallocation, reduced transparency, and tunneling (e.g., Shleifer and Vishny, 1997 and Dyck and Zingales, 2004). These activities make valuation more difficult.

To test this hypothesis, I use the La Porta, Lopez, Shleifer, and Vishny (1996, 1997, 1999 and 2000) definitions of legal regime and accounting standards quality. La Porta el al. argue that common law countries have better investor protections laws and practices than firm in civil law countries. I use the target's firm country of incorporation and its legal regime in my analysis of $H 2.2$. Moreover, La Porta, Lopez, Shleifer, and Vishny (1998) measure the degree of accounting standards for most of my sample countries. I use their measure of accounting standards in my analysis.

Panel A of Table 9 reports the results of the following OLS regression model: 
$C A R_{i, t}^{(-2,+2)}=\alpha_{0}+\beta_{1}(F D)_{i, t}+\beta_{2}(F D * L R \text { or } A S)_{i, t}+\sum_{x=1}^{j} \gamma_{x} Z_{i, t}+e_{i, t}$

Where LR refers to the legal regime and AS refers to the accounting standards of the target firm in a cross-border merger. LR is equal to one if the target firm is from a civil law country and zero otherwise. AS is the accounting standard score of the target firm. H2.2 implies a positive (negative) and significant coefficient of $\beta_{2}$ when using LR (AS) as an interaction effect with FD. Panel A shows that there are no significant coefficients for any of the interaction effects of FD and AS or LR. These initial results are inconsistent with investor protection or accounting standards effects explaining merger announcement period returns to the acquirer.

As a more restrictive test of $H 2.2$, I include the legal regime and accounting standards for the home country of the foreign director as well as that of the acquiring firm. Specifically, I argue that the benefits to cross-border acquirers might be higher when the foreign director comes from a country with a stronger legal regime or accounting standards than those of the acquiring firm ${ }^{27}$.

A foreign director who comes from a country with a better legal regime or stronger accounting standards than the acquirer firm might have a better understanding of international legal practices and the issues associated with global finance. Moreover, foreign directors who come from a stronger legal regime might be more knowledgeable about international law. Thus, foreign directors can be valuable to acquirers in reducing the legal challenges faced with cross-border acquisitions. These challenges can be costly

\footnotetext{
${ }^{27}$ Miletkov, Poulsen and Wintoki (2012) find support for the same argument.
} 
to the acquiring firm. Thus, reducing them increases the synergy potential of the crossborder merger.

In panel B of Table 9, I estimate the following OLS regression model:

$\operatorname{CAR}_{i, t}^{(-2,+2)}=\alpha_{0}+\beta_{1}($ Better Legal (accounting $\left.) F D\right)_{i, t}+\sum_{x=1}^{j} \gamma_{x} Z_{i, t}+e_{i, t}$

Where Better Legal FD is a binary variable that equals to one if the foreign director is from a common law country and the acquirer is from a civil law country and zero otherwise. Better accounting FD is a binary variable that equals to one if the foreign director is from a country with stronger accounting standards than the acquiring firm and zero otherwise. The results of panel B demonstrates that foreign directors who are from a better legal regime or accounting standards than the acquirer firm generate higher CARs.

The results of Table 9 do not provide evidence in support of H2.2. But, for a subset of foreign directors whose home country has stronger investor protection or accounting standards than the acquiring firm have a positive influence on announcement period abnormal returns. This result shows that a foreign director's benefit to crossborder acquirers is more pronounced when they are from a country with stronger investor protections or accounting standards. A foreign director's knowledge about international law and business practices might signal to investors that the acquiring firms are pursuing value enhancing cross-border targets. 


\section{Foreign directors and merger targets}

\section{Public status of target firms (H3.1)}

I argue in $H 3.1$ that cross-border acquirers are more likely to acquire privately held targets. Private firms are difficult to value because their financial position is not known to the public (Capron and Shen, 2007 and Erel, Kiao and Weisbach, 2012). Moeller and Schlingemann (2005) find that most cross-border acquisitions rarely involve private targets. However, the M\&A literature argues that acquiring private targets is value-increasing because less information on private targets creates more value-creating opportunities for exploiting private information (Capron and Shen, 2007).

I argue that the presence of foreign directors on acquirer's boards allows acquirers to better exploit this private information. If the valuation of privately-held target is difficult, then acquirers need private information that gives them the opportunity to assess the true value of the target. Foreign directors are more likely to have the weak-tie networks that will provide them with this information, thus allowing the acquirer to make competitive offers.

To test this hypothesis, I follow the same empirical procedures used in Table 6. That is, I use Logit, Poisson, and OLS analysis to examine the impact of foreign directors on the type of target pursued. For my dependent variables, I use the probability that a cross-merger target is a privately-held target, the number of cross-border mergers that involve privately-held targets in a given year, and the dollar volume of cross-border mergers that involve privately-held targets in a given year respectively.

The results are reported in Table 10. Panel A reports my univariate analysis. Private target is a binary variable that equals to one if the cross-border merger involves a 
privately-held target and zero otherwise. The SDC database classifies targets as public, private, government owned, joint venture, mutual, and subsidiary. To test the hypothesis as stated, I delete mergers that involve government owned, joint venture, mutual, and subsidiary targets. From this univariate analysis, I observe that firms with foreign directors are less likely to pursue a privately-held target in a given year. But they have a higher number of cross-border mergers involving a privately-held target and they put more dollars into deals that involve privately-held targets.

Panels B, C, and D exhibit the results of my Logit, Poisson, and OLS analysis of H3.1 respectively. The Logit analysis does not show any significant coefficient for the foreign director measures ${ }^{28}$. However, Panel C shows a strong support for this hypothesis. All the coefficient estimates for the foreign director measures have significant positive coefficients at the $1 \%$ level. Firms with foreign directors commit to a higher number of cross-border mergers that involve a privately-held target than firms without foreign directors.

My OLS analysis supports H3.1. Panel D shows that the coefficients of FD, the number of FD, percent of FD on boards, and FID are positive and significant. The presence of foreign directors leads acquirers to put more dollars in cross-border mergers that involve privately-held targets in a given year.

In general, I find support of H3.1. The presence of foreign directors on boards leads to a higher number of cross-border deals that involve privately-held targets over my sample period. Moreover, firms with foreign directors put more dollars into deals that involve privately-held targets. Although the results from the Logit models do not show

\footnotetext{
${ }^{28}$ In unreported results, I estimate the logit model based on a balanced sample similar to panel E of Table 7. The results do not show any significant coefficients for the foreign director measures.
} 
significant coefficients, the results from the Poisson and OLS analyses are consistent with the hypothesis.

\section{Target valuation (H3.2)}

I find in section 6.2.1 that cross-border acquirers with foreign directors enjoy higher announcement period returns. One reason that these acquirers experience these higher returns is that they might target relatively undervalued targets. Consequently, I argue in $H 3.2$ that firms with foreign directors are more likely to acquire targets that are undervalued.

Targets that are undervalued (mispriced) do not require overpayment relative to targets that are overvalued. Indeed, Dos Santos, Errunza and Miller (2008) find that cross-border acquisitions of "fairly-valued" targets do not lead to value destruction. However, managers of the acquiring firms might be reluctant to bid for such firms if they are perceived as a bad investment due to their low price. I argue in $H 3.2$ that foreign directors might be better able to identify "attractive" targets abroad and recommend them to acquirers. Moreover, I argue that foreign directors are more likely to challenge managers who might bid for over-valued targets.

To test this hypothesis, I collect data on target firms from the WorldScope database. Specifically, I calculate the market-to-book ratio for target firms in my sample $^{29}$. I use this ratio as my measure of the under valuation of target firms. Then, I estimate the following OLS model to test the hypothesis:

$$
\text { Target } M B_{i, t-1}=\alpha_{0}+\beta_{1}(F D)_{i, t}+\sum_{x=1}^{j} \gamma_{x} Z_{i, t}+e_{i, t}
$$

\footnotetext{
${ }^{29}$ I lose few observations because some cross-border mergers involve privately-held targets as discussed in the previous section.
} 
Where Target $M B_{i, t-1}$ is the target's market-to-book ratio during the year preceding the year of the merger announcement. Support for $H 3.2$ means that $\beta_{1}$ is negative and significant.

Table 11 reports the results. All the foreign director measures show negative coefficient estimates. The coefficients of FD and the first and second lags of FD are significantly negative. These results are consistent with H3.2.Firms with foreign directors tend to acquire targets that are relatively undervalued compared to firms with no foreign directors. This might explain why cross-border acquirers with foreign directors enjoy higher announcement period returns.

\section{Foreign directors and cross-border merger payment}

\section{Merger premium (H4.1)}

I argue in $H 4.1$ that cross-border acquirers with foreign directors on their boards are more likely to pay less for their targets. Overpayment for targets can be a form of value-destruction that managers might pursue during their tenure (Harford, HumpheryJenner and Powell, 2012). Paying higher premium is often associated with loss in shareholder value (Baker, Pan, and Wurgler, 2012).

I contend that foreign directors help cross-border acquirers negotiate a better deal that results in a lower offer price. This lower bid price might result from the foreign director's possession of weak-ties with various parties located in the country of the target. These weak-ties can eliminate conflicts that might arise during the merger negotiation. Foreign directors might also be able to negotiate a better offer price because of their ability to reduce the effect of homophily. 
To test this hypothesis, I compare the value of the transaction to the target firm's market valuation one year before the merger. Specifically, I estimate the following OLS regression:

$$
\frac{\text { Value of transaction }}{\text { Target } M k t \operatorname{Cap}_{i, t-1}}=\alpha_{0}+\beta_{1}(F D)_{i, t}+\sum_{x=1}^{j} \gamma_{x} Z_{i, t}+e_{i, t}
$$

Where Value of transaction is the dollar value of the cross-border merger transaction as reported by the SDC database and Target Mkt Cap ${ }_{i, t-1}$ is the market capitalization of the target firm $i$ in year $t-1$ as reported in WorldScope database ${ }^{30}$. I hypothesize in $H 4.1$ that the left hand side of equation (13) is low for firms with foreign directors. Thus, evidence in support of this hypothesis implies a negative and significant coefficient for $\beta_{1}$.

Table 12 presents my results. The coefficients of the foreign director measure strongly support H4.1. Five of the six measures have significantly negative coefficients. Thus, I conclude that the presence of foreign directors on an acquirer's boards leads to lower payments for their cross-border targets than acquirers without foreign directors.

\section{Foreign directors and the method of payment (H4.2)}

I argue in $H 4.2 a$ that cross-border acquirers with foreign directors on their boards are more likely to use cash in their payment for cross-border acquisitions. There is a high degree of information asymmetry between acquirers and targets especially in crossborder mergers. A higher degree of information asymmetry between the acquirer and

\footnotetext{
${ }^{30}$ The dependent variable in equation (13) is widely used in the literature to test for merger overpayment (e.g., Sung 1993). However, it is used as a per share basis. That is, the offer price per share divided by the target's stock price. I estimate the term in aggregate basis because international firm's stock price data is missing for a lot of observations in my sample. The results should yield the same conclusion in both cases.
} 
target induce acquirers to issue equity to finance the merger. Hansen (1987) argues that since managers of the acquiring firm do not know the true value of the target, they prefer to finance the merger with stock. I argue in $H 4.2 a$ that foreign directors reduce this information asymmetry, and thus, acquirers with foreign directors are more likely to use cash in their cross-border mergers.

On the other hand, I argue in $H 4.2 b$ that cross-border acquirers with foreign directors on their boards are more likely to use stocks in their payment for cross-border mergers. Managers might prefer to pay for acquisitions with cash for two reasons. Harford, Humphery-Jenner and Powell (2012) argue that entrenched managers use cash instead of equity because they do not want to create new equity blockholders. Other managers prefer cash over equity because they think that their equity is undervalued. Thus, these managers are reluctant to use their stock to pay for their acquisitions. I expect that foreign directors are more likely to challenge the decisions reached by managers if they use cash as a method of payment when they should use equity.

Table 13 reports the results of my analysis of these two competing hypotheses. Panel A reports my initial univariate analysis of the method of payment for my mergers. D_Cash is a dummy variable that equals to one if the method of payment in the crossborder merger is cash and zero otherwise. D_Mixed is a dummy variable that equal to one if the method of payment is mixed and zero otherwise. D_Equity is a dummy variable that equal to one if the method of payment is equity and zero otherwise ${ }^{31} . \%$ Cash is the percentage of cash used in the transaction.

\footnotetext{
${ }^{31}$ Mixed payments are those that involve cash and equity at the same time.
} 
The results of this univariate analysis support $H 4.2 a$. Firms with foreign directors use more cash in their payment for cross-border targets. This is clear from the results of the D_Cash and \%Cash variables.

In my multivariate analysis, I estimate the following logit model:

$$
\operatorname{Pr}\left(D_{-} \text {Cash }=1 \mid X\right)_{i, t}=\text { Logit }\left[\alpha_{0}+\beta_{1}(F D)_{i, t}+\sum_{x=1}^{j} \gamma_{x} Z_{i, t}+e_{i, t}\right]
$$

The results are reported in panel B of Table 13. The results support H4.2b. The coefficients of the FD measures are negative and significant. This result implies that firms with foreign directors are more likely to use equity as a method of payment for their cross-border mergers.

In further analysis of these two competing hypotheses, I estimate the following Tobit regression:

$$
\% \text { Cash }=\alpha_{0}+\beta_{1}(F D)_{i, t}+\sum_{x=1}^{j} \gamma_{x} Z_{i, t}+e_{i, t}
$$

The results are reported in panel $\mathrm{C}$ of Table 13 . The results support $H 4.2 b$. The coefficients for the foreign directors are negative and significant in five of the six models. Thus, the results of my multivariate analyses support $H 4.2 b$ and contradict the univariate results of panel A.

In general, I conclude that firms with foreign directors are more likely to use equity in the payment of their cross-border targets. The results of my multivariate analyses support this conjecture and support H4.2b. Although Panel A of Table 13 implies a support for $H 4.2 a$, panels B and C arrive at a different conclusion. 


\section{Chapter 7: ROBUSTNESS TESTS}

In this Chapter, I explore alternative explanations that might drive my results. I conclude that firms with foreign directors engage in a higher frequency of cross-border mergers. This conclusion, however, might be driven by the fact that firms who intend to engage in cross-border mergers choose to import foreign directors because of their advantages. Indeed, I discuss throughout this study many advantages that foreign directors bring to corporate boards and how they might benefit cross-border acquirers. It might be that the decision to recruit foreign directors is itself be correlated with the decision to engage in a cross-border merger. In other words, self-selection, endogeneity, or unobservable characteristics issues might be the driver behind my main results. To control for these effects, I use two methodologies: propensity score matching and the Heckman (1979) adjustment.

\section{Propensity score matching}

Despite my conclusion that firms with foreign directors engage in higher frequency of cross-border mergers, other explanations might drive my results. For example, it might be that foreign directors do not increase the likelihood of cross-border mergers, but firms who decide to engage in cross-border mergers hire foreign directors. That is, reverse causality might be the driver behind my results. To correct this possible effect, I need to control for unobservable firm characteristics that might increase the likelihood that a firm engages in a cross-border merger. Specifically, I use the propensity score matching method similar to Aggarwal, Erel, Stulz, and Williamson (2010). 
I match firms based on a set of firm characteristics as described by Aggarwal et al. (2010). Specifically, I match firms on assets, ROA, foreign assets, foreign sales, leverage, cash, and board size. I compute the propensity that a firm has a foreign director using the following Probit model:

$$
\operatorname{Pr}(F D=1 \mid X)_{i, t}=\text { Probit }\left[\alpha_{0}+\sum_{x=1}^{j} \gamma_{x} Z_{i, t}+e_{i, t}\right]
$$

Where $Z_{i, t}$ are the characteristics mentioned above. Based on this model, each firm gets a score based on its characteristics. I match a firm with a foreign director in a particular country in a particular year and industry with a firm with no foreign directors based on the closet score. I then estimate a t-statistic between these two groups of firms to examine their propensity to engage in cross-border mergers. The reason behind this test is that I examine the difference between two groups of firms after controlling for all possible observable and unobservable characteristics. That is, I match two sets of firms where the only difference is the main variable of interest which is the presence of foreign directors.

The results of my propensity score matching tests are reported in Table 14. I use FD, the first and second lags of FD, and FID as my separation variables (i.e., the left hand side of equation 16). I report the differences between the two sets of firms based on the dollar volume of cross-border mergers a firm commits to in a particular year, a binary variable that a firm commits to a cross-border merger in a particular year, and the number of cross-border mergers a firm commits to in a particular year.

The results are consistent with my earlier results. After controlling for similarities for firms with and without foreign directors, firms with foreign directors are more likely 
to engage in a cross-border merger, commit more dollars to cross-border mergers, and engage in higher number of cross-border mergers in a particular year. The results are robust at the 99 percent level. Each of the four separation variables demonstrates a similar significance. I conclude that my earlier results are robust and are unlikely to be driven by unobservable firm characteristic.

\section{Heckman (1979) methodology}

I employ Heckman's (1979) methodology, sometimes called the treatment effect model, to control for possible endogeneity with my results. That is, firms might appoint foreign directors because they anticipate engaging in future cross-border mergers, rather than foreign directors influence the decision to engage in such mergers. I adjust for this potential self-selection by using Heckman's (1979) two-stage procedure.

I assume that a firm's decision to appoint a foreign director is determined by

$$
\operatorname{Pr}(F D=1 \mid X)_{i, t}=\text { Probit }\left[\sum_{x=1}^{j} \gamma_{x} Z_{i, t}+\mu_{i}\right]
$$

Where $Z_{i, t}$ are those firm characteristics influencing the decision to appoint foreign directors while $\mu_{i}$ is an error term. Then, the expected decision to engage in a cross-border merger conditional on the firm having a foreign director can be written as:

$E($ CrossBorder $=1 \mid F D=1)=\alpha_{0}+\sum_{x=1}^{j} \gamma_{x} Z_{i, t}+$ Fixed effects $+E\left(e_{i} \mid F D=1\right)$

Assuming that the error terms in (17) and (18) have a bivariate normal distribution with mean zero and a standard deviation of 1 and $\sigma$ respectively, and a correlation of $\rho$, then $E\left(e_{i} \mid F D=1\right)=\pi \lambda_{1}\left(\gamma_{x} Z_{i, t}\right)$ where 


$$
\lambda 1\left(\gamma_{x} Z_{i, t}\right)=\frac{\phi\left(\gamma_{x} Z_{i, t}\right)}{\phi\left(\gamma_{x} Z_{i, t}\right)}
$$

Where $\phi($.$) and \phi($.$) are the density and cumulative distribution functions of the$ standard normal respectively and $\pi=\rho \sigma^{32}$.

In the first stage of the Heckman (1979) two-stage procedure, I use a Probit regression (equation 17) to obtain estimates of $\gamma_{x}$ and then I use these estimates to compute $\lambda 1$. In the second stage, I estimate the following equations to examine several different aspects of cross-border activity:

$$
\begin{aligned}
& \operatorname{Pr}(\text { CrossBorder }=1 \mid X)_{i, t}=\text { Logit }\left[\alpha_{0}+\beta_{1}(F D)_{i, t}+\sum_{x=1}^{j} \gamma_{x} Z_{i, t}+\lambda 1+e_{i, t}\right] \\
& \text { Log(Num_CrossBorder })_{i, t}=\alpha_{0}+\beta_{1}(F D)_{i, t}+\sum_{x=1}^{j} \gamma_{x} Z_{i, t}+\lambda 1+e_{i, t} \\
& \text { CrooBorder_Volume }_{i, t}=\alpha_{0}+\beta_{1}(F D)_{i, t}+\sum_{x=1}^{j} \gamma_{x} Z_{i, t}+\lambda 1+e_{i, t}
\end{aligned}
$$

These equations are similar to equations (1), (2), and (3) of section 6.1.1; however, they are corrected by the Heckman (1979) two-stage procedure. In the first stage, I include all (and only) the firm controls from the second stage to identify the determinants of the choice to appoint a foreign director. This means that I have no "exclusion restrictions" and there is no need to justify an external exogenous instrument. Exclusion restrictions are not necessary in the Heckman selection model because the model is identified by non-linearity (Li and Prabhala 2007). My self-selection regressions will yield consistent estimates even without exclusion restrictions.

\footnotetext{
${ }^{32}$ The ratio in (19) sometimes referred to as the Inverse Mills Ratio (IMR).
} 
Table 15 reports the results of my Heckman (1979) analysis. The table shows the results of the second stage of the analysis. Panel A exhibit the results from equation (20). All four measures of foreign directors show positive and significant coefficients. The presence of foreign directors increases the likelihood that a firm engages in cross-border mergers even after controlling for self-selection and endogeneity concerns. Panels B and $\mathrm{C}$ report the results from equations (21) and (22) respectively. All foreign director measures show positive and significant coefficients. I conclude that the presence of foreign directors increases the number of cross-border mergers a firm pursues and the dollar volume that a firm commits to cross-border mergers in a particular year even after controlling for endogeneity concerns.

\section{Concluding remarks on robustness tests}

While endogeneity is a possibility, the propensity score matching and Heckman (1979) approaches correct for many possible biases. I conclude from my propensity score matching results that no unobservable firm characteristics drive the decision to engage in cross-border merger activity. I show that even after controlling for these unobservable characteristics, firms which appoint foreign directors engage in subsequent cross-border mergers more frequently.

Second, my results might suffer from reverse causality. That is, firms who decide to engage in cross-border mergers appoint foreign directors beforehand. This effect weakens my conclusion that foreign directors by themselves influence the decision to engage in cross-border mergers. The Heckman (1979) approach correct for this possibility, allowing me to conclude that foreign directors do influence the decision to engage in cross-border mergers. 
Using these methodologies, I conclude that foreign directors influence the likelihood that acquirers engage in cross-border mergers, the dollar volume of such deals, and the number of cross-border mergers a firm pursues. My propensity score matching and Heckman (1979) results show that these conclusions are robust to alternative explanations that might arise from endogeneity. 


\section{Chapter 8: CONCLUSION}

I argue in this study that a special subset of directors on corporate boards exerts a distinct advising influence on corporate decision-making. I argue that foreign directors, those that do not share the same nationality as the firm of which they are directors, have a unique effect on the cross-border merger decision of firms. This unique effect stems from the enhancement of the decision-making ability that those foreign directors bring to corporate boards.

I begin my analysis by hypothesizing that firms with foreign directors are more likely to engage in cross-border mergers. I contend that cross-border acquirers face special legal, cultural, and informational challenges that foreign directors are better able to address thus leading to greater levels of cross-border merger activity. I find that firms with foreign directors engage in a higher number of cross-border mergers, invest more dollars in cross-border mergers, and are more likely to engage in cross-border mergers than firms without foreign directors.

Moreover, I hypothesize and find that firms with foreign directors are more likely to engage in non-diversifying mergers. Diversifying mergers are well-known to be value destroying to acquirers. This is consistent with the ability of foreign directors to bring new perspectives and information to the board that enhances the decision-making process.

I hypothesize and find that firms with foreign directors are more likely to engage in friendly mergers with their cross-border targets. Foreign directors can help to bridge the cultural divide between target and acquirer, thus leading to a more friendly merger. 
This phenomenon is referred to as cultural affinity which is a feeling of closeness to others who share the same culture or values (Calomiris, Kahn, and Longhofer, 1994 and Hunter and Walker, 1996). Such cultural affinity can help to eliminate obstacles in merger negotiations and consequently a greater incidence of friendly mergers.

I then examine the effect of foreign directors on the performance of cross-border mergers. Masulis, Wang and Xie (2012) find that the presence of foreign directors on U.S. acquirer's boards leads to stronger cross-border mergers performance, but only when the target is from the same geographical region as the foreign director. I find a broader effect, and that the inter-cultural competencies of foreign directors extend beyond that of their home region. Specifically, I find firms with foreign directors have higher cross-border acquisition announcement returns relative to firms without foreign directors. I also find that a foreign director's benefit to cross-border acquirers is more pronounced when they are from a country with stronger investor protections or accounting standards. If foreign directors have greater knowledge about international law and business practices, then their presence on a board might signal to investors that the acquiring firms are pursuing more value enhancing cross-border targets.

Next, I examine the types of targets that cross-border acquirers with foreign directors might pursue. I find that acquirers with foreign directors on their boards are more likely to target privately held firms. Private targets are more difficult to value and constitute a challenge when an acquirer bids for them (Capron and Shen, 2007 and Erel, Kiao and Weisbach, 2012). Foreign directors however, might be more likely to have information about these targets through their 'weak-ties' connections. Moreover, I find that acquirers with foreign directors are more likely to pursue targets that are 
undervalued. Again, foreign directors often have private information about potential targets through their network of 'weak-ties'.

Finally, I examine a foreign director's impact on cross-border merger payment in terms of premium and method of payment. I find that firms with foreign directors pay less for their cross-border targets relative to acquirers without foreign directors. A foreign director can help to increase the cultural fit between the acquirer and the target. This increase in the cultural affinity between acquirer and target can ultimately result in a lower price as negotiation obstacles are more easily resolved. Moreover, foreign directors can use their 'weak-ties' to eliminate negotiation obstacles and facilitate the merger process, ultimately resulting in a lower target price.

Moreover, I find that firms with foreign directors are more likely to use equity in the payment of their cross-border targets. Managers might prefer cash instead of equity either because they think their equity is undervalued (Malmendier and Tate, 2008 and Ferris, Jayaraman, and Sabherwal, 2013) or they hesitate to give other parties a huge percentage of ownership and thereby challenge the manager in his private benefits of control (Harford, Humphery-Jenner and Powell, 2012). Since foreign directors challenge managers by reducing groupthink, the presence of foreign directors on acquirer's boards leads to a greater use of equity as merger payment.

This research expands our understanding of how board diversity in the form of foreign directors can enhance board advising effectiveness. As companies seek foreign acquisitions, they face difficult legal, cultural, and informational challenges that can impede merger competition. Foreign directors play a key role in reducing these challenges and help to bridge the cultural gap between the acquirer and target. Moreover, 
I contend that foreign directors have influence not just on performance, but also on other important aspects on the merger process.

This research also answers important questions regarding the effect of diversity in corporate boards (e.g., Adams and Ferreira 2004). It adds to this literature by focusing on how diversity within a board influences a strategic decision such as a cross-border merger. Social scientists often ask whether demographic diversity matter in organizations. Diversity might decrease group loyalty and thus hinders the decisionmaking process. On the other hand, diversity might foster the thinking process within groups by alternative opinions and different points of view thus enhancing the decisionmaking process. This study contributes to this strand of literature by giving a positive view on a special subset of directors that positively influence the advising role for boards of directors.

I also contribute to the M\&A literature by focusing on how foreign directors on acquirer's board can affect a merger. Such influence in unexplored in previous literature and I argue that foreign directors play a critical role in different aspects of the merger process and performance. Foreign directors reduce the cultural conflicts that might arise in cross-border mergers that usually negatively influence international merger activity (Ahern, Daminelli and Fracassi, 2012). I also show that the negotiation process before mergers are critical for the success of the merger. Thus, boards should pay attention to ways to reduce any hurdles that might arise during negotiations with the target firm. I show that board demographics play a critical role in this regard.

This study raises important questions about the role of foreign directors on corporate boards. I look at the advising role of foreign directors on boards by examining 
their influence on cross-border mergers. However, an important question remaining for future work is whether foreign directors affect the monitoring role of corporate boards. For example, do foreign directors influence CEO compensation in a way that increases firm value? Masulis, Wang and Xie (2012) examine both the monitoring and advising roles of foreign directors in U.S. corporate boards. Similar to this study, they find a positive effect of foreign directors on U.S. boards in terms of their advising role. However, they find that foreign directors negatively affect the monitoring role of corporate boards. An important extension of this study is whether such negative effect is internationally present and to what extent it varies with cultural and legal differences. An important question remaining to be answered is whether other aspects of board diversity similarly affect strategic corporate decision-making. For example, I argue that the "foreignness" of the board positively influence its advising role. Does the "foreignness" resulting from gender or race diversity have an effect on the decisionmaking processes of the board? Plus, as Earley and Mosakowski (2000) argue, more than the optimal level of heterogeneity might have a negative effect on the decision making ability among groups. Such arguments raise important questions for future research to explore. 


\section{REFERENCES:}

Adams, R., \& Ferreira, D. (2004). Gender Diversity in the Boardroom. ECGI Working Paper Series in Finance.

Adams, R., Hermalin, B., \& Weisbach, M. (2010). The Role of Boards of Directors in Corporate Governance: A Conceptual Framework and Survey. Journal of Economic Literature, 48, 58-107.

Adler, P., \& Kwon, S.-W. (2002). Social Capital: Prospects for a New Concept. The Academy of Management Review, 17-40.

Aggarwal, R., Erel, I., Stulz, R., \& Williamson, R. (2010). Differences in Governance Practices between U.S. and Foreign Firms: Measurement, Causes, and Consequences. Review of Financial Studies, (23) 3131-3169.

Ahern, K., Daminelli, D., \& Fracassi, C. (2012). Lost in Translation? The Effect of Cultural Values on Mergers Around the World. Journal of Financial Economics, forthcoming.

Aldag, R. J., \& Fuller, S. R. (1993). Beyond Fiasco: A Reappraisal of the Groupthink Phenomenon and a New Model of Group Decision Processes. Psychological Bulletin, 113 (3): 533-552.

Almack, J. (1922). The Influence of Intelligence on the Selection of Associates. School and Society, (16) 529-530.

Amihud, Y., Lev, B., \& Travlos, N. (1990). Corporate Control and the Choice of Investment Financing: The Case of Corporate Acquisitions. The Journal of Finance, 45, 603-66.

Baker, M., Pan, X., \& Wurgler, J. (2012). The Effect of Reference Point Prices on Mergers and Acquisitions. Journal of Financial Economics, 106, 49-71.

Bantel, K., \& Jackson, S. (1989). Top Management and Innovations in Banking: Does the Composition of the Top Team Make a Difference? Strategic Management Journal, (10)107-124.

Blau, P. (1977). Inequality and Heterogeneeity: A Primitive Theory of Social Structure. New York: Free Press.

Bodnar, G., Tang, C., \& Weintrop, J. (1999). Both Sides of Corporate Diversification: The Value Impacts of Geographic and Industrial Diversification. NBER Working Paper.

Boeker, W. (1997). Strategic change: The Influence of Managerial Characteristics and Organizational Growth. Academy of Management Journal, 152-170. 
Bott, H. (1929). Observation in Play Activities in a Nursery School. Psychol. Monogr., (4) 44-88.

Brickley, J., \& Zimmerman, J. (2010). Corporate Governance Myths: Comments on Armstrong, Guay, and Weber. Journal of Accounting and Economics, 85, 66-101.

Bris, A., \& Cabolis, C. (2008). The Value of Investor Protection: Firm Evidence from Cross-Border Mergers. The Review of Financial Studies, 21, 605-648.

Burkart, M., \& Panuzi, F. (2006). Takeovers. Financial Markets and Institutions: An European Perspective.

Burt, R. (1992). Structural Holes: The Social Structure of Competition. Cambridge, MA: Harvard University Press.

Burt, R. (2004). Structural Holes and Good Ideas. American Journal of Sociology.

Byrne, D. (1969). Attitudes and Attraction: Advances in Experimental Social Psychology. Austin TX: Department of Psychology - University of Texas at Austin.

Cai, Y., \& Sevilir, M. (2012). Board Connections and M\&A Transactions. Journal of Financial Economics, 103, 327-349.

Calomiris, C., Kahn, C., \& Longhofer, S. (1994). Housing-Finance Intervention and Private Incentives: Helping Minorities and the Poor. Journal of Money, Credit and Banking, 634-674.

Capron, L., \& Shen, J.-C. (2007). Acquisitions of Private vs. Public Firms: Private Information, Target Selection, and Acquirer Returns. Strategic Management Journal, 891-911.

Chakrabarti, R., Gupta-Mukherjee, S., \& Jayaraman, N. (2009). Mars-Venus Marriages: Culture and Cross-Border M\&A. Journal of International Business Studies, 40, 216-236.

Chang, S. (1998). Takeovers of Privately Held Targets, Methods of Payment, and Bidder Returns. The Journal of Finance, 53, 773-784.

Chari, A., Ouimet, P., \& Tesar, L. (2010). The Value of Control in Emerging Markets. The Review of Financial Studies, 23,1741-1770.

Christophe, S. (1997). Hysteresis and the Value of the U.S. Multinational Corporation. The Journal of Business, 70, 435-462.

Coisne, C. (2011). Managing Culture in International Mergers and Acquisitions. Working paper.

Costa, D., \& Kahn, M. (2003). Civic Engagement and Community Heterogeneity: An Economist's Perspective. Perspective on Politics, 103-111.

Cox, T. (1993). Cultural Diversity in Organizations. San Francisco: Berrett Koehler. 
Cox, T., Lobel, S., \& McLeod, P. (1991). Effects of Ethnic Group Cultural Differences on Cooperative and Competitive Behavior on a Group Task. Academy of management journal, (34) 827-847.

Denis, D., Denis, D., \& Yost, K. (2002). Global Diversification, Industrial Diversification, and Firm Value. The Journal of Finance, 57, 1951-1979.

Dos Santos, M., Errunza , V., \& Miller, D. (2008). Does Corporate International Diversification Destroy Value? Evidence From Cross-Border Mergers and Acquisitions. Journal of Banking and Finance, 32, 2716-2724.

Dyck, A., \& Zingales, L. (2004). Private Benefits of Control: An International Comparison. The Journal of Finance, 59, 537-600.

Earley, P., \& Mosakowski, E. (2000). Creating Hybrid Team Culture: An Empirical Test of Transnational Team Functioning. Academy of Management Journal, (43) 2649.

Erel, I., Liao, R., \& Weisbach, M. (2012). Determinants of Cross-Border Mergers and Acquisitions. The Journal of Finance, forthcoming.

Erickson, B. (2003). Social Networks: The Value of Variety. American Sociological Association.

Errunza, V., \& Senbet, L. (1981). The Effects of International Operations on the Market Value of the Firm: Theory and Evidence. The Journal of Finance, 36, 401-417.

Errunza, V., \& Senbet, L. (1984). International Corporate Diversification, Market Valuation, and Size-Adjusted Evidence. The Journal of Finance, 39, 727-743.

Faccio, M., \& Masulis, R. (2005). The Choice of Payment Method in European Mergers and Acquisitions. The Journal of Finance, 60, 1345-1388.

Ferris, S., Jayaraman , N., \& Sabherwal, S. (2013). CEO Overconfidence and International Merger and Acquisition Activity. Journal of Financial and Quantitative Analysis, 137 - 164.

Ferris, S., Kim, K., \& Noronha, G. (2009). The Effect of Crosslisting on Corporate Governance: A Review of the International Evidence. Corporate Governance: An International Review, 17, 338-352.

Fishman, M. J. (1989). Preemptive Bidding and the Role of the Medium of Exchange in Acquisitions. The Journal of Finance, 44, 41-57.

Francis, B., Hasan, I., \& Sun, X. (2008). Financial Market Integration and the Value of Global Diversification: Evidence for US Acquirers in Cross-Border Mergers and Acquisitions . Journal of Banking and Finance, 32, 1522-1540. 
Fuller, K., Netter, J., \& Stegemoller, M. (2002). What Do Returns to Acquiring Firms Tell Us? Evidence from Firms That Make Many Acquisitions. The Journal of Finance, 57, 1763-1793.

Ghosh, A., \& Ruland, W. (1998). Managerial Ownership, the Method of Payment for Acquisitions, and Executive Job Retention. The Journal of Finance, 53, 785-798.

Granovetter, M. S. (1973). The Strengths of Weak Ties. American Journal of Sociology, (78) 1360-1380.

Granovetter, M. S. (1983). The Strength of Weak Ties: A Network Theory Revisited. Sociological theory.

Granovetter, M. S. (2005). The Impact of Social Structure on Economic Outcomes. The Journal of Economic Perspectives, 33-50.

Grossman, S., \& Hart, O. (1980). Takeover Bids, The Free-Rider Problem, and the Theory of the Corporation. The Bell Journal of Economics, 11, 42-64.

Hambrick, D. C., Cho, T. S., \& Chen, M.-J. (1996). The Influence of Top Management Team Heterogeneity on Firms' Competitive Moves. Administrative Science Quarterly, (41) 659-684.

Hambrick, D., \& Mason, P. (1984). Upper Echelons: The Organization as a Reflection of its Top Managers. Academy of management review, (9) 193-206.

Hansen, R. (1987). A Theory for the Choice of Exchange Medium in Mergers and Acquisitions. Journal of Business, 60, 75-95.

Harford, J., Humphery-Jenner, M., \& Powell, R. (2012). The Sources of Value Destruction in Acquisitions by Entrenched Managers. Journal of Financial Economics, 247-261.

Hart, P. (1991). Irving L. Janis' Victims of Groupthink. Political Psychology, 2 (12): 247-278.

Heckman, J. (1979). Sample Selection Bias as a Specification Error. Econometrica, (47) 153-161.

Hermalin, B., \& Weisbach, M. (2003). Boards of Directors as an Endogenously Determined Institution: A Survey of Economic Literature. FRBNY Economic Policy Review, 9, 7-26.

Holthausen, R. W. (2009). Accounting Standards, Financial Reporting Outcomes, and Enforcement. Journal of Accounting Research, 47, 447-458.

Hunter, W., \& Walker, M. (1996). The Cultural Affinity Hypothesis and Mortgage Lending Decisions. The Journal of Real Estate Finance and Economics, 57-70. 
Ibarra, H. (1992). Homophily and Differential Returns: Sex Differences in Network Structure and Access in an Advertising Firm. Administrative Science Quarterly, (37) 422-447.

Ishii, J., \& Xuan, Y. (2010). Acquirer-Target Social Ties and Merger. Working Ppaper.

Jackson, S. E. (1992). Diversity in the Workplace: Human Resources Initiatives. New York: Guilford.

Janis, I. (1971). Groupthink. Psychology Today, 5 (6): 43-46, 74-76.

Janis, I. (1972). Victims of Groupthink: a Psychological Study of Foreign-Policy Decisions and Fiascoes. Boston: Houghton Mifflin.

Janis, I. (1982). Groupthink: Psychological Studies of Policy Decisions and Fiascoes. Boston: Houghton Mifflin.

Jensen, M. (1986). Agency Costs of Free Cash Flow, Corporate Finance, and Takeovers. The American Economic Review, 76,323-329.

Kim, W., \& Lyn, E. (1986). Excess Market Value, the Multinational Corporation, and Tobin's q-Ratio. Journal of International Business Studies, 17, 119-125.

La Porta, R., Lopez-de-Silanes, F., Shleifer , A., \& Vishny , R. (1998). Law and Finance. Journal of Political Economy.

La Porta, R., Lopez-de-Silanes, F., Shleifer, A., \& Vishny, R. (1997). Legal Determinants of External Finance. The Journal of Finance, 52, 1131-1150.

La Porta, R., Lopez-de-Silanes, F., Shleifer, A., \& Vishny, R. (1999). Corporate Ownership Around the World. The Journal of Finance, 54, 471-517.

La Porta, R., Lopez-de-Silanes, F., Shleifer, A., \& Vishny, R. (2000). Investor Protection and Corporate Goernance. Journal of Financial Economics, 58, 3-27.

Lazarsfeld, P., \& Merton, R. (1954). Friendship as a Social Process: A Substantive and Methodological Analysis. In Freedom and Control in Modern Society, Morroe Berger, Theodore Abel, and Charles H. Page, eds. New York: Van Nostrand, 1866.

Li, K., \& Prabhala, N. (2007). Self-Selection Models in Corporate Finance. In E. Eckbo, Hankbook of Corporate Finance: Empirical Corporate Finance (pp. Ch. 2, 3786). Elsevier/North-Holland.

Loomis, C. (1946). Political and Occupational Cleavages in a Hanoverian Village. Sociometry, (9) 316-333.

Lott, A. J., \& Lott, B. E. (1965). Group Cohesiveness as Interpersonal Attraction: A Review of Relationships with Antecedent and Consequent Variables. Psychological bulletin, 64(4) 259. 
Luttmer, E. F. (2001). Group Loyalty and the Taste for Redistribution. Journal of Political Economy, (109) 500-528.

Malmendier, U., \& Tate, G. (2008). Who Makes Acquisitions? CEO Overconfidence and the Market's Reaction. Journal of Financial Economics, 20-43.

Martin, K. J. (1996). The Method of Payment in Corporate Acquisitions, Investment Opportunities, and Management Ownership. The Journal of Finance, 51, 12271246.

Martynova, M., \& Renneboog, L. (2008). Spillover of Corporate Governance Standards in Cross-Border Mergers and Acquisitions. Journal of Corporate Finance, 14, 200-223.

Martynova, M., Oosting, S., \& Renneboog, L. (2006). The Long-Term Operating Performance of European Mergers and Acquisitions. Working Ppaper.

Masulis, R., Wang, C., \& Xie, F. (2012). Globalizing the Boardroom-The Effects of Foreign Directors on Corporate Governance and Firm Performance. Journal of Accounting and Economics, 53, 527-554.

McPherson, M., Smith-Lovin, L., \& Cook, J. (2001). Birds of Feather: Homophily in Social Networks. Annual Review of Sociology, (27) 415-444.

Miletkov, M., Poulsen, A., \& Wintoki, B. (2013). A Multinational Study of Foreign Directors on Non-U.S. Corporate Boards. Working Paper.

Moeller, S., \& Schlingemann, F. (2005). Global Diversification and Bidder Gain: A Comparison Between Cross-Border and Domestic Acquisitions. Journal of Banking and Finance, 29, 553-564.

Moeller, S., \& Schlingemann, F. (2005). Wealth Destruction on a Massive Scale? A Study of Acquiring-Firm Returns in the Recent Merger Wave. The Journal of Finance, 60, 757-782.

Morck, R., \& Yeung, B. (1991). Why Investors Value Multinationality. The Journal of Business, 165-187.

Morosini, P., Shane, S., \& Singh, H. (1998). National Cultural Distance and CrossBorder Acquisition Performance. Journal of International Business Studies, 29, 137-158.

Moscovici, S. (1976). Social influence and social change. London: Academic Press.

Myers, D. G. (1999). Social Psychology. McGraw-Hill College.

Nemeth, C. J. (1986). Differential Contribution of Majority and Minority Influence. Psychological Review, (93) 23-32.

Officer, M. (2007). The Price of Corporate Liquidity: Acquisition Discounts for Unlisted Targets. Journal of Financial Economics, 83, 571-598. 
Officer, M., Poulsen, A., \& Stegemoller, M. (2009). Target-Firm Information Asymmetry and Acquirer Returns. Review of Finance, 13, 467-493.

O'Reilly, C., Caldwell , D., \& Barnett, W. (1989). Work Group Demography, Social Integration, and Turnover. Administrative Science Quarterly, (34) 21-37.

Pfeffer, J. (1983). Organizational Demography. Research in Organizational Behavior, (4) 299-357.

Pound, J. (1988). Proxy Contests and the Efficiency of Shareholder Oversight. Journal of Financial Economics, 20, 237-265.

Rhodes-Kropf, M., \& Viswanathan, S. (2004). Market Valuation and Merger Waves. The Journal of Finance, 59, 2685-2718.

Rhodes-Kropf, M., \& Viswanathan, S. (2005). Valuation Waves and Merger Activity: The Empirical Evidence. Journal of Financial Economics, 77, 561-603.

Richardson, H. (1940). Community of Values a Factorin Friendships of College and Adult Women. The Journal of Social Psychology, (25) 335-361.

Roll, R. (1986). The Hubris Hypothesis of Corporate Takeovers. The Journal of Business, 59, 197-216.

Rossi, S., \& Volpin, P. (2004). Cross-Country Determinants of Mergers and Acquisitions. Journal of Financial Economics, 74, 277-304.

Ruef, M., Aldrich, H., \& Carter, N. (2003). The Structure of Founding Teams: Homophily, String Ties, and Isolation Among U.S. Entrepreneurs. American Sociological Review, (68.2) 195-222.

Schonlau, R., \& Singh, P. (2009). Board Networks and Merger Performance. Working Ppaper.

Servaes, H. (1991). Tobin's Q and the Gains from Takeovers. The Journal of Finance, 46, 409-419.

Servaes, H. (1996). The Value of Diversification During the Conglomerate Merger Wave. The Journal of Finance, 51, 1201-1225.

Shimizu, K., Hitt, M., Vaidyanath, D., \& Pisano, V. (2004). Theoretical Foundations of Cross-Border Mergers and Acquisitions: A Review of Current Research and Recommendations for the Future. Journal of International Management, 10, 307353.

Shleifer, A., \& Vishny, R. (1997). A Survey of Corporate Governance. The Journal of Finance, 52, 737-783.

Shleifer, A., \& Vishny, R. W. (2003). Stock Market Driven Acquisitions. Journal of Financial Economics, 70, 259-311. 
Shrum, W., Cheek, N., \& Hunter, S. (1988). Friendship in School: Gender and Racial Homophily. Sociology of education, (61) 227-239.

Stahl, G., \& Vogit, A. (2008). Do Cultural Differences Matter in Mergers and Acquisitions? A Tentative Model and Examination. Organization Science, 19, 160-176.

Starks, L., \& Wei, K. (2013). Cross-Border Mergers and Differences in Corporate Governance. International Review of Finance, forthcoming.

Stulz, R. M. (1988). Managerial Control of Voting Rights . Journal of Financial Economics, 20, 25-54.

Sung, H. (1993). The Effects of Overpayment and Form of Financing on Bidder Returns in Mergers and Tender Offers. Journal of Financial Research, 351-365.

Travlos, N. G. (1987 ). Corporate Takeover Bids, Methods of Payment, and Bidding Firms' Stock Returns. The Journal of Finance, 42, 943-963.

Tsui, A., Egan, T., \& O'Reilly, C. (1992). Being Different: Relational Demography and Organizational Attachment. Administrative Science Quarterly, (37) 549-579.

Wasserman, S., \& Faust, K. (1994). Social Network Analysis in the Social and Behavioral Sciences. Social Network Analysis: Methods and Applications, 1-27.

Watson, W., Kumar, K., \& Michaelsen, L. (1993). Cultural Diversity's Impact on Interaction Process and Performance: Comparing Homogeneous and Diverse Task Groups. Academy of Management Journal, (36) 590-602.

Wiersema, M., \& Bantel, K. (1992). Top Management Team Demography and Corporate Strategic Change. Academy of Management Journal, (35) 91-121.

Woolcock, M., \& Narayan, D. (2000). Social Capital: Implications for Development Theory, Research, and Policy. The World Bank Research Observe, 225-249. 


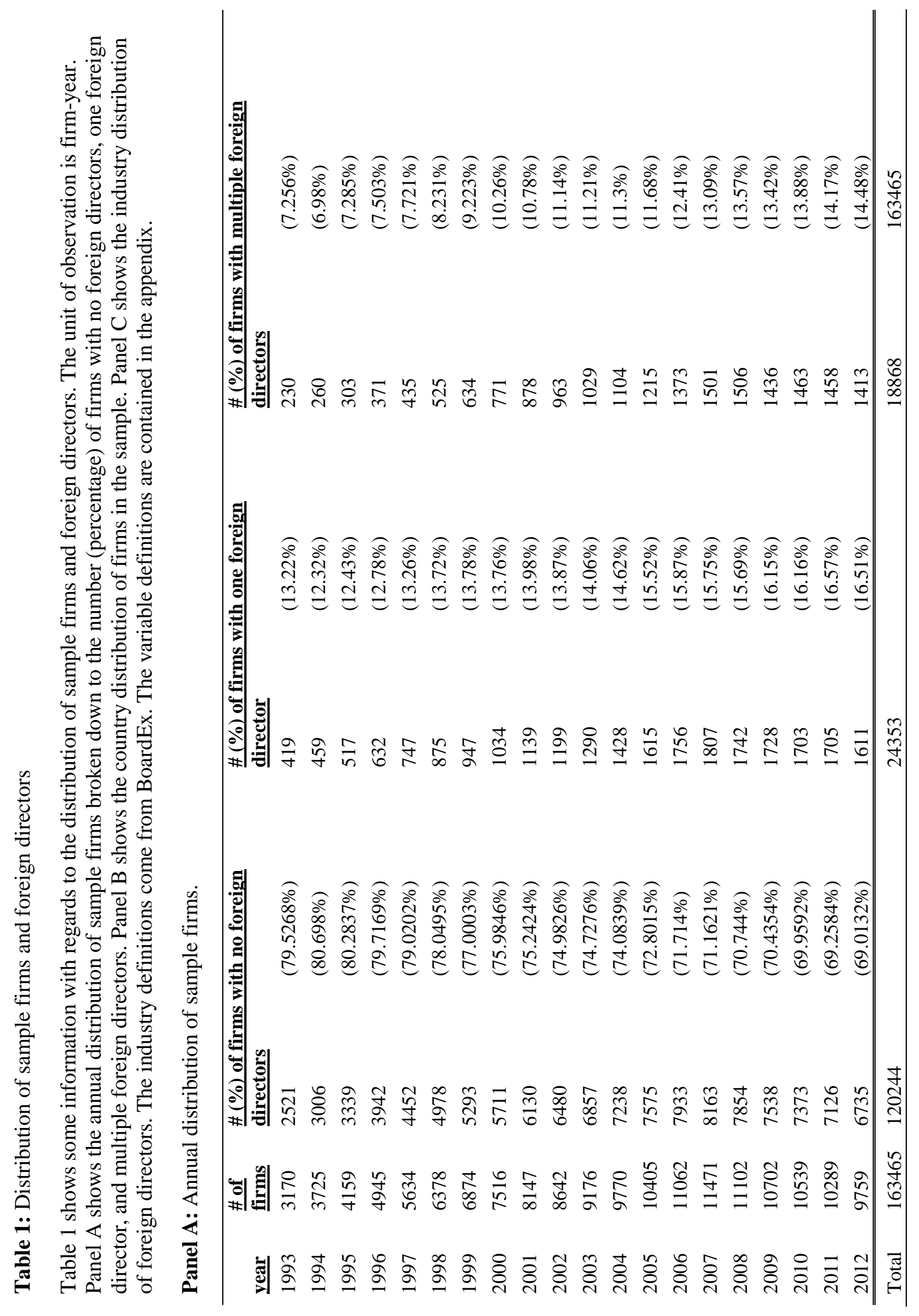




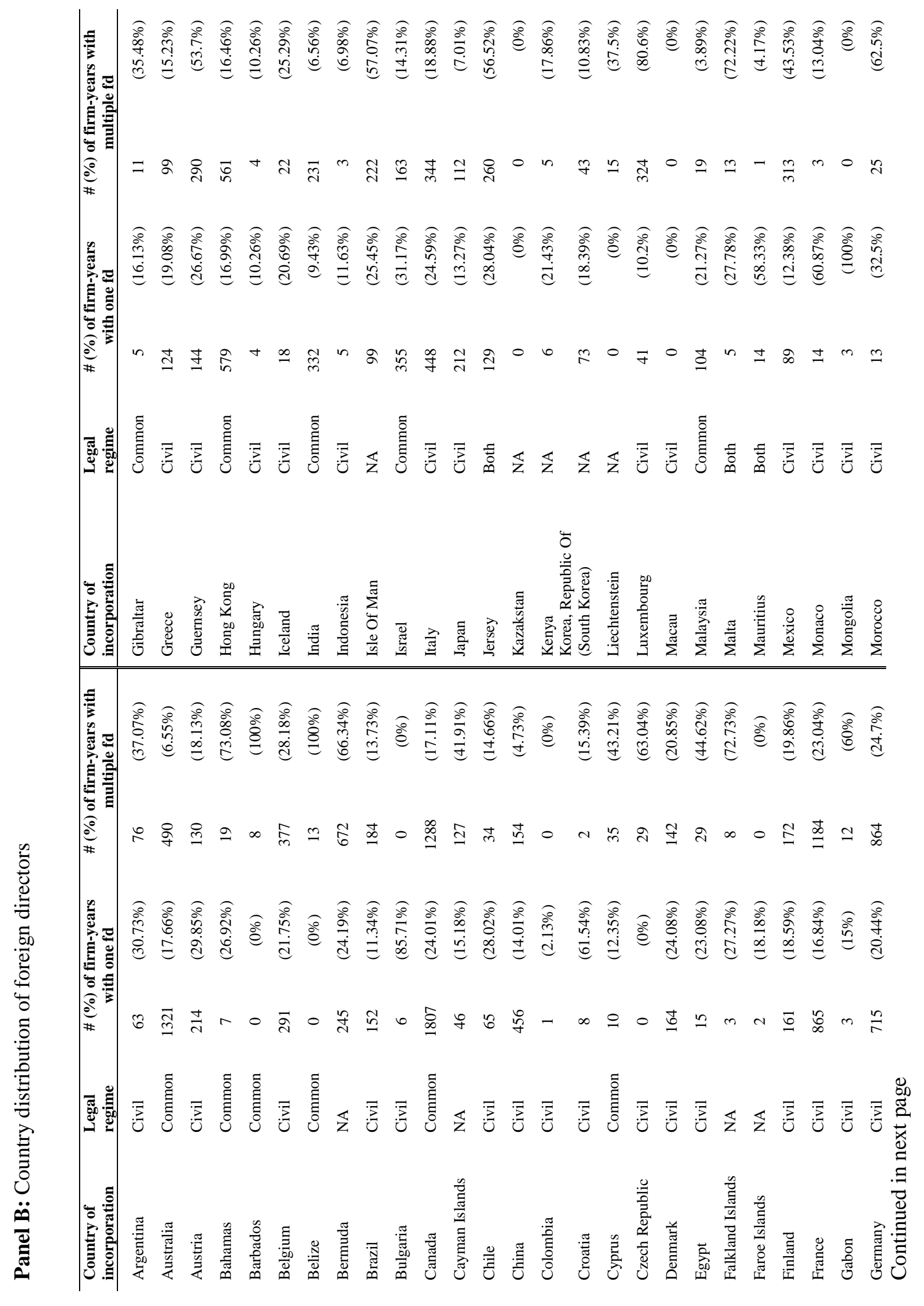




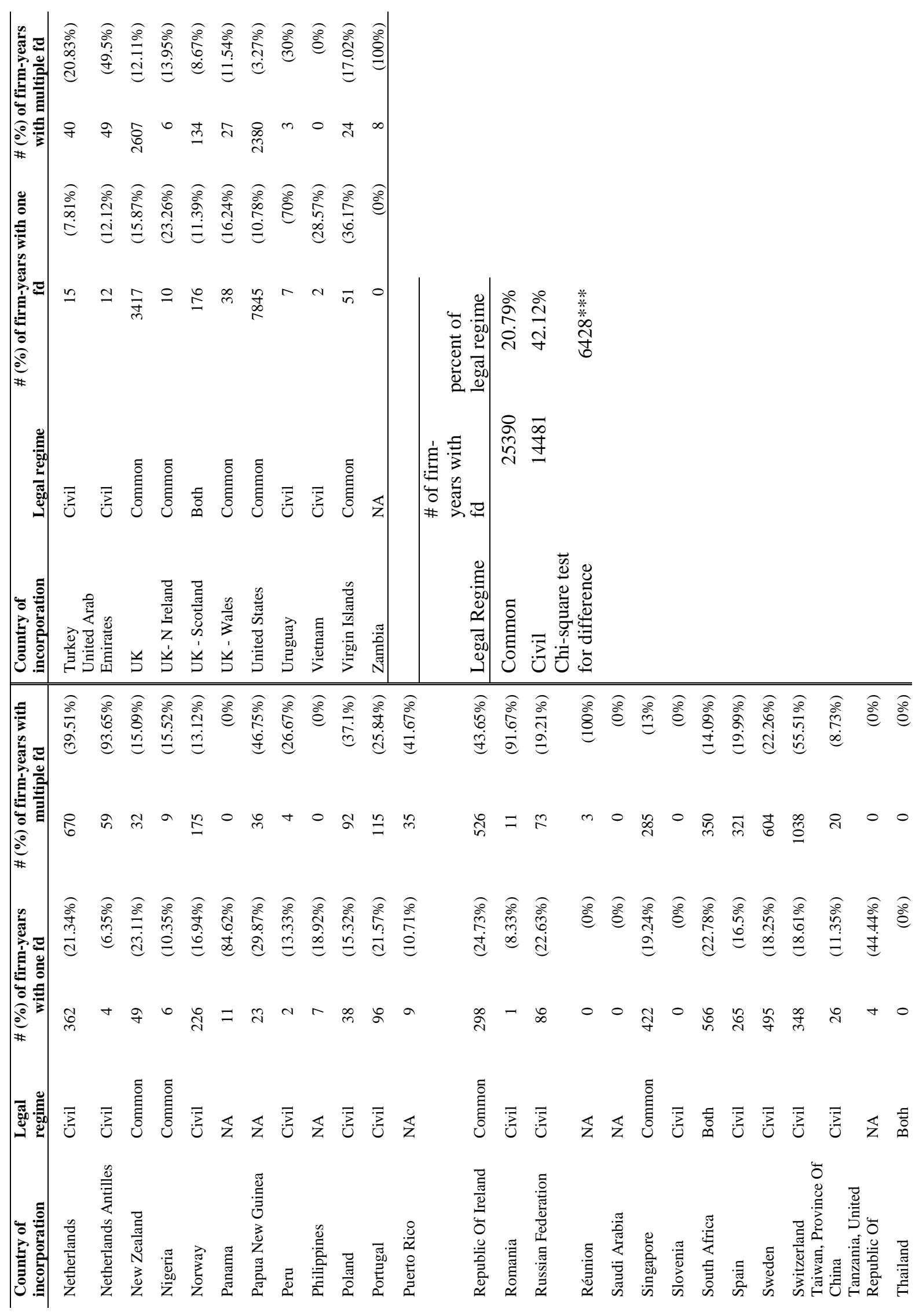


Panel C: Industry distribution of foreign directors

\begin{tabular}{lcccr}
\hline Sector Name & \# $(\%)$ of firm-years with one fd & \# $(\%)$ of firm-years with multiple fd \\
\cline { 2 - 3 } Aerospace \& Defense & 175 & $(16.11 \%)$ & 97 & $(8.93 \%)$ \\
Automobiles \& Parts & 337 & $(15.27 \%)$ & 360 & $(16.31 \%)$ \\
Banks and Financial Services & 5191 & $(22.62 \%)$ & 4559 & $(17.08 \%)$ \\
Construction \& Building Materials & 1914 & $(16.37 \%)$ & 1248 & $(12.06 \%)$ \\
Diversified Industrials & 680 & $(18.62 \%)$ & 731 & $(20.02 \%)$ \\
Electricity, Electronic Equipment & 1681 & $(30.85 \%)$ & 845 & $(22.71 \%)$ \\
Food, Drug Retailers \& Processors & 1128 & $(31.19 \%)$ & 1063 & $(26.44 \%)$ \\
General Retailers & 800 & $(12.48 \%)$ & 503 & $(7.04 \%)$ \\
Health \& Household Products & 1875 & $(28.57 \%)$ & 986 & $(12.66 \%)$ \\
Leisure \& Hotels & 563 & $(14.04 \%)$ & 448 & $(11.17 \%)$ \\
Media \& Entertainment & 877 & $(17.65 \%)$ & 919 & $(18.49 \%)$ \\
Oil, Gas, Mining \& Renewable Energy & 3031 & $(16.43 \%)$ & 2301 & $(14.19 \%)$ \\
Pharmaceuticals and Biotechnology & 1919 & $(18.25 \%)$ & 1538 & $(13.97 \%)$ \\
Software \& Computer Services & 2023 & $(14.82 \%)$ & 1186 & $(7.57 \%)$ \\
Steel \& Other Metals & 304 & $(14.43 \%)$ & 288 & $(13.68 \%)$ \\
Telecommunication Services & 604 & $(15.05 \%)$ & 815 & $(20.3 \%)$ \\
Tobacco & 66 & $(26.4 \%)$ & 67 & $(26.8 \%)$ \\
Transport & 830 & $(14.19 \%)$ & 690 & $(11.79 \%)$ \\
Utilities & 235 & $(9.2 \%)$ & 194 & $(7.59 \%)$ \\
Wholesale Trade & 120 & $(13.64 \%)$ & 30 & $(3.41 \%)$ \\
\hline
\end{tabular}




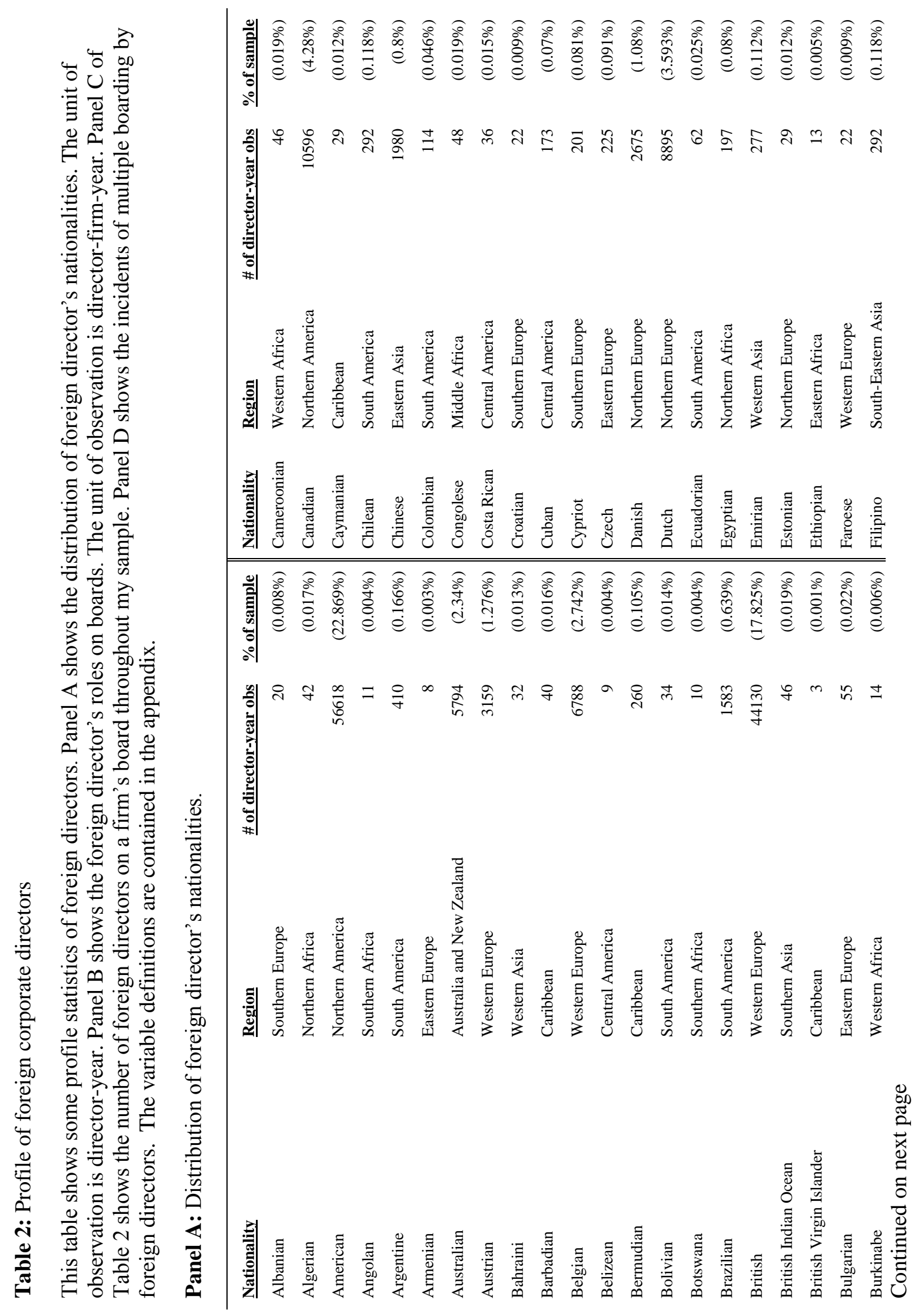




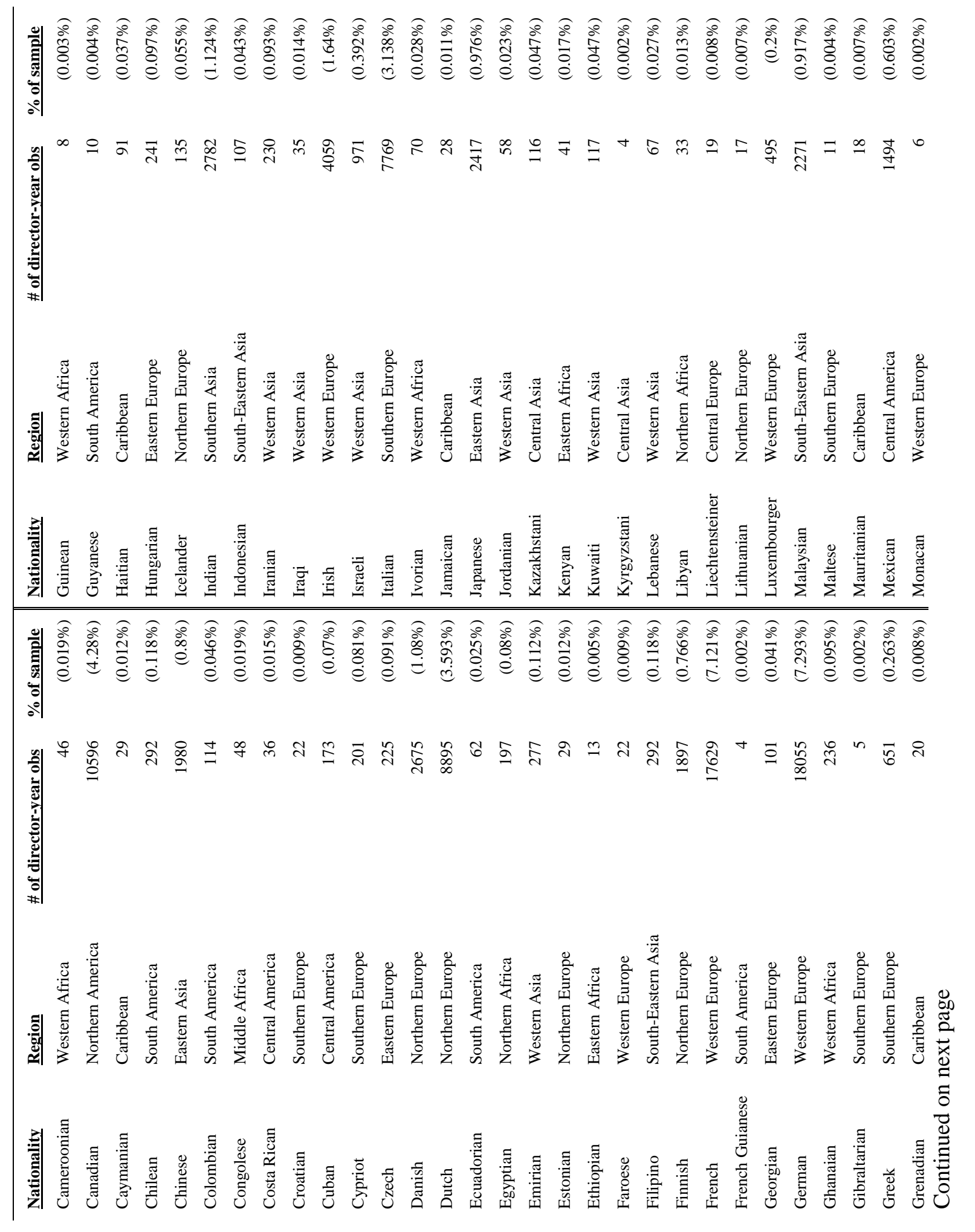




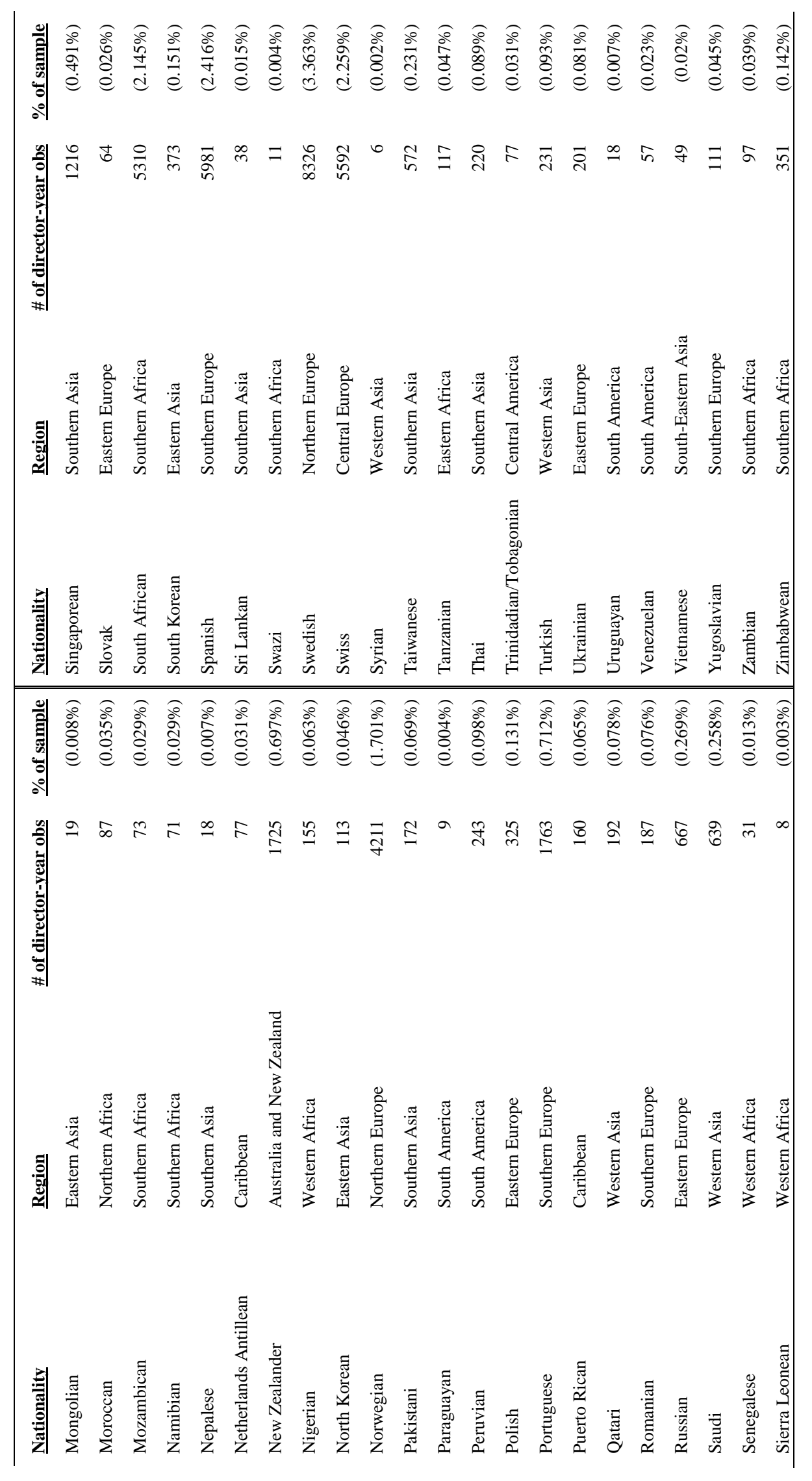


Panel B: Foreign director's role on boards

\begin{tabular}{|c|c|c|}
\hline$\underline{\text { Role }}$ & \# of director-firm-years with fd & $\%$ of director-firm-years with $\mathrm{fd}$ \\
\hline CEO & 3516 & $14.53 \%$ \\
\hline chairman & 7397 & $15.02 \%$ \\
\hline chairman/CEO & 1094 & $7.88 \%$ \\
\hline Independent & 35807 & $12.15 \%$ \\
\hline Acquisition committee & 65 & $11.34 \%$ \\
\hline Auditing committee & 14810 & $12.44 \%$ \\
\hline Compensation committee & 6684 & $9.19 \%$ \\
\hline Nomination committee & 5461 & $20.85 \%$ \\
\hline
\end{tabular}

Panel C: Incidence of foreign directors

\begin{tabular}{ccc}
\hline \# of fd on a firm's board & \# of firm-year obs & $\frac{\text { \% of sample }}{(73.56 \%)}$ \\
\cline { 2 - 3 } 1 & 120244 & $(14.9 \%)$ \\
2 & 24353 & $(5.39 \%)$ \\
3 & 8809 & $(2.54 \%)$ \\
$>3$ & 4154 & $(3.6 \%)$ \\
\hline
\end{tabular}

Panel D: Multiple boarding by foreign directors

\begin{tabular}{ccc}
\hline \# of board seats per director & \# of director-firm-year obs & \% of sample \\
\cline { 2 - 3 } 1 & 57323 & $81.83 \%$ \\
2 & 9239 & $13.19 \%$ \\
3 & 2286 & $3.26 \%$ \\
$>3$ & 1206 & $1.72 \%$ \\
\hline
\end{tabular}


Table 3: Sample firm and merger characteristics

This table shows some univariate analyses of some variables for firms with and without foreign directors. Panels A and B compares the means of some variables between firms with no foreign directors and firms with one director or firms with multiple foreign directors respectively. Panels C and D compare some M\&A variables between firms with no foreign directors and firms with one or multiple foreign directors respectively. $*, * *$, and $* * *$ indicate significance at the $10 \%, 5 \%$, and $1 \%$ levels respectively. The variable definitions are in the appendix.

Panel A: Comparative firm characteristics, one foreign director

\begin{tabular}{|c|c|c|c|}
\hline$\underline{\text { Variable }}$ & Firms with one fd & firms with no fd & $\underline{\text { Test statistic }}$ \\
\hline Assets & 11798740 & 4937290 & $14.56^{* * *}$ \\
\hline Market value of equity & 4743752 & 1906578 & $24.37 * * *$ \\
\hline Debt / Assets & 0.9504 & 0.5758 & 1.08 \\
\hline ROA & -1.2328 & -0.6689 & -1.04 \\
\hline Board Size & 7.7734 & 6.1966 & $55.16^{* * *}$ \\
\hline Foreign Assets & 0.000304 & 0.000215 & 1.46 \\
\hline Foreign Sales & 0.00044 & 0.0004 & 0.85 \\
\hline Book Value of equity & 2012546 & 887605 & $21.06 * * *$ \\
\hline Tobin's Q & 2.6539 & 2.4261 & 0.39 \\
\hline Cash & 0.0223 & 0.1906 & -1 \\
\hline Board Independence & 0.4746 & 0.5745 & $-28.5 * * *$ \\
\hline
\end{tabular}

Panel B: Comparative firm characteristics, multiple foreign directors

\begin{tabular}{|c|c|c|c|}
\hline Variable & $\underline{\text { Firms with multiple fd }}$ & $\underline{\text { firms with no fd }}$ & $\underline{\text { Test statistic }}$ \\
\hline Assets & 40520120 & 4937290 & $26.2 * * *$ \\
\hline Market value of equity & 10877648 & 1906578 & $43.45^{* * *}$ \\
\hline Debt / Assets & 0.5682 & 0.5758 & 0.86 \\
\hline $\mathrm{ROA}$ & 2.8285 & -0.6689 & $7.44 * * *$ \\
\hline Board Size & 10.5775 & 6.1966 & $108.89 * * *$ \\
\hline Foreign Assets & 0.00155 & 0.000215 & 1.02 \\
\hline Foreign Sales & 0.000429 & 0.0004 & 0.26 \\
\hline Book Value of equity & 4960816 & 887605 & $40.47 * * *$ \\
\hline Tobin's Q & 2.2235 & 2.4261 & 0.66 \\
\hline Cash & 0.1736 & 0.1906 & $-2.25^{* *}$ \\
\hline Board Independence & 0.3864 & 0.5745 & $-49.23 * * *$ \\
\hline
\end{tabular}


Panel C: Comparative merger characteristics, one foreign director

\begin{tabular}{|c|c|c|c|}
\hline Variable & Firms with one fd & firms with no fd & Test statistic \\
\hline Merger & 0.2963 & 0.2326 & $21.26 * * *$ \\
\hline Cross-border merger & 0.4309 & 0.2456 & $30.76 * * *$ \\
\hline Cash payment & 0.000153 & 0.000149 & 0.06 \\
\hline Hostile merger & 0.00554 & 0.00441 & 1.25 \\
\hline Purchase price & 0.209 & 0.357 & $-1.92 *$ \\
\hline Private target & 0.386 & 0.4535 & $-11.05 * * *$ \\
\hline$\%$ of shares acquired & 81.7975 & 87.941 & $-14.34 * * *$ \\
\hline Diversifying merger & 0.4646 & 0.4628 & 0.29 \\
\hline
\end{tabular}

Panel D: Comparative merger characteristics, multiple foreign directors

\begin{tabular}{|c|c|c|c|}
\hline$\underline{\text { Variable }}$ & $\underline{\text { Firms with multiple fd }}$ & firms with no fd & $\underline{\text { Test statistic }}$ \\
\hline Merger & 0.3528 & 0.2326 & $35.22 * * *$ \\
\hline Cross-border merger & 0.6701 & 0.2456 & $72.48 * * *$ \\
\hline Cash payment & 0.000048 & 0.000149 & $-6.28 * * *$ \\
\hline Hostile merger & 0.00766 & 0.00441 & $3.08 * * *$ \\
\hline Purchase price & 0.098 & 0.357 & $-5.93 * * *$ \\
\hline Private target & 0.3047 & 0.4535 & $-25.08 * * *$ \\
\hline$\%$ of shares acquired & 74.3513 & 87.941 & $-28.24 * * *$ \\
\hline Diversifying merger & 0.4886 & 0.4628 & $4.09 * * *$ \\
\hline
\end{tabular}


Table 4: The effect of foreign directors on cross-border mergers

This table shows the results of testing hypothesis H1.1. The unit of observation is firm-year observation. Panel A reports the results of a Poisson regression where the dependent variable is the number of crossborder mergers a firm commits to in a year. Panel B reports the results of an OLS regression where the dependent variable is the dollar volume a firm puts into cross-border mergers. Panel C reports the results of a Logit regression where the dependent variable is one if a firm commits to a cross-border merger in a particular year and zero otherwise. *,**, and *** indicate significance at the $10 \%, 5 \%$, and $1 \%$ levels respectively. P-values are reported in parenthesis. The variable definitions are in the appendix.

Panel A: Poisson analysis of cross-border mergers

\begin{tabular}{|c|c|c|c|c|c|c|}
\hline & $(1)$ & $(2)$ & $(3)$ & $(4)$ & (5) & (6) \\
\hline FD & $\begin{array}{l}0.7086^{* * * *} \\
(<.0001)\end{array}$ & & & & & \\
\hline $\mathrm{FD}_{\mathrm{t}-1}$ & & $\begin{array}{l}0.7037 * * * \\
(<.0001)\end{array}$ & & & & \\
\hline $\mathrm{FD}_{\mathrm{t}-2}$ & & & $\begin{array}{l}0.7067 * * * \\
(<.0001)\end{array}$ & & & \\
\hline \#FD & & & & $\begin{array}{l}0.1387 * * * \\
(<.0001)\end{array}$ & & \\
\hline$\%$ FD on board & & & & & $\begin{array}{l}1.5057 * * * \\
(<.0001)\end{array}$ & \\
\hline FID & & & & & & $\begin{array}{l}0.6727 * * * * \\
(<.0001)\end{array}$ \\
\hline $\log (\text { Assets })_{t-1}$ & $\begin{array}{l}0.3509 \\
(<.0001)\end{array}$ & $\begin{array}{l}0.3501 \\
(<.0001)\end{array}$ & $\begin{array}{l}0.3493 \\
(<.0001)\end{array}$ & $\begin{array}{l}0.3552 \\
(<.0001)\end{array}$ & $\begin{array}{l}0.3505 \\
(<.0001)\end{array}$ & $\begin{array}{l}0.3516 \\
(<.0001)\end{array}$ \\
\hline $\mathrm{ROA}_{\mathrm{t}-1}$ & $\begin{array}{l}0.0011 \\
(<.0001)\end{array}$ & $\begin{array}{l}0.0011 \\
(<.0001)\end{array}$ & $\begin{array}{l}0.0011 \\
(<.0001)\end{array}$ & $\begin{array}{l}0.0011 \\
(<.0001)\end{array}$ & $\begin{array}{l}0.0012 \\
(<.0001)\end{array}$ & $\begin{array}{l}0.0011 \\
(<.0001)\end{array}$ \\
\hline Board Size $\mathrm{t}_{-1}$ & $\begin{array}{l}-0.025 \\
(<.0001)\end{array}$ & $\begin{array}{l}-0.0241 \\
(<.0001)\end{array}$ & $\begin{array}{l}-0.0235 \\
(<.0001)\end{array}$ & $\begin{array}{l}-0.0293 \\
(<.0001)\end{array}$ & $\begin{array}{l}-0.0056 \\
(<.0001)\end{array}$ & $\begin{array}{l}-0.0197 \\
(<.0001)\end{array}$ \\
\hline Board Independence & $\begin{array}{l}-0.2947 \\
(<.0001)\end{array}$ & $\begin{array}{l}-0.2961 \\
(<.0001)\end{array}$ & $\begin{array}{l}-0.297 \\
(<.0001)\end{array}$ & $\begin{array}{l}-0.3165 \\
(<.0001)\end{array}$ & $\begin{array}{l}-0.2969 \\
(<.0001)\end{array}$ & $\begin{array}{l}-0.445 \\
(<.0001)\end{array}$ \\
\hline Duality & $\begin{array}{l}-0.0405 \\
(0.0140)\end{array}$ & $\begin{array}{l}-0.0421 \\
(0.0106)\end{array}$ & $\begin{array}{l}-0.0454 \\
(0.0059)\end{array}$ & $\begin{array}{l}-0.0202 \\
(0.2185)\end{array}$ & $\begin{array}{l}-0.0252 \\
(0.1251)\end{array}$ & $\begin{array}{l}-0.0353 \\
(0.0325)\end{array}$ \\
\hline Foreign Assets $\mathrm{t}_{\mathrm{t}-1}$ & $\begin{array}{l}0.0007 \\
(0.0042)\end{array}$ & $\begin{array}{l}0.0007 \\
(0.0025)\end{array}$ & $\begin{array}{l}0.0008 \\
(<.0001)\end{array}$ & $\begin{array}{l}0.0007 \\
(0.0005)\end{array}$ & $\begin{array}{l}0.0007 \\
(<.0001)\end{array}$ & $\begin{array}{l}0.0008 \\
(<.0001)\end{array}$ \\
\hline Foreign Sales $\mathrm{t}_{\mathrm{t}-1}$ & $\begin{array}{l}0.0006 \\
(<.0001)\end{array}$ & $\begin{array}{l}0.0006 \\
(<.0001)\end{array}$ & $\begin{array}{l}0.0006 \\
(<.0001)\end{array}$ & $\begin{array}{l}0.0006 \\
(<.0001)\end{array}$ & $\begin{array}{l}0.0006 \\
(<.0001)\end{array}$ & $\begin{array}{l}0.0005 \\
(<.0001)\end{array}$ \\
\hline Intercept & $\begin{array}{l}-6.7843 \\
(<.0001) \\
\end{array}$ & $\begin{array}{l}-6.7821 \\
(<.0001) \\
\end{array}$ & $\begin{array}{l}-6.7712 \\
(<.0001) \\
\end{array}$ & $\begin{array}{l}-6.6355 \\
(<.0001) \\
\end{array}$ & $\begin{array}{l}-6.8078 \\
(<.0001) \\
\end{array}$ & $\begin{array}{l}-6.6473 \\
(<.0001) \\
\end{array}$ \\
\hline $\mathrm{N}$ & 98708 & 98708 & 98708 & 98708 & 98708 & 98708 \\
\hline Year Fixed effects & Yes & Yes & Yes & Yes & Yes & Yes \\
\hline Clustered St errors at the country level & Yes & Yes & Yes & Yes & Yes & Yes \\
\hline
\end{tabular}


Panel B: OLS analysis of cross-border mergers

CrooBorder_Volume $_{i, t}=\alpha_{0}+\beta_{1}(F D)_{i, t}+\sum_{x=1}^{j} \gamma_{x} Z_{i, t}+e_{i, t}$

\begin{tabular}{|c|c|c|c|c|c|c|}
\hline & (1) & (2) & (3) & (4) & (5) & (6) \\
\hline \multirow[t]{2}{*}{ FD } & $83.1529 * * *$ & & & & & \\
\hline & $(0.003)$ & & & & & \\
\hline \multirow[t]{2}{*}{$\mathrm{FD}_{\mathrm{t}-1}$} & & $85.2543 * * *$ & & & & \\
\hline & & $(0.0034)$ & & & & \\
\hline \multirow[t]{2}{*}{$\mathrm{FD}_{\mathrm{t}-2}$} & & & $80.0515^{* *}$ & & & \\
\hline & & & $(0.0107)$ & & & \\
\hline \multirow[t]{2}{*}{ \#FD } & & & & $77.1782 * *$ & & \\
\hline & & & & $(0.0387)$ & & \\
\hline \multirow[t]{2}{*}{$\%$ FD on board } & & & & & $689.4951 * * *$ & \\
\hline & & & & & $(<.0001)$ & \\
\hline \multirow[t]{2}{*}{ FID } & & & & & & 27.2008 \\
\hline & & & & & & $(0.5768)$ \\
\hline \multirow[t]{2}{*}{$\log (\text { Assets })_{t-1}$} & 151.9013 & 151.6766 & 151.7733 & 147.7255 & 146.8098 & 153.4531 \\
\hline & $(<.0001)$ & $(<.0001)$ & $(<.0001)$ & $(0.0002)$ & $(0.0001)$ & $(<.0001)$ \\
\hline \multirow[t]{2}{*}{$\mathrm{ROA}_{\mathrm{t}-1}$} & -0.0158 & -0.01 & -0.0136 & 0.0878 & 0.0828 & -0.0313 \\
\hline & $(0.9862)$ & $(0.9912)$ & $(0.9880)$ & $(0.9268)$ & $(0.9295)$ & $(0.9721)$ \\
\hline \multirow[t]{2}{*}{ Board Size ${ }_{t-1}$} & 28.567 & 28.6392 & 28.864 & 21.9921 & 30.407 & 30.2521 \\
\hline & $(0.0003)$ & $(.0003)$ & (.0004) & $(0.0006)$ & $(<.0001)$ & $(0.0001)$ \\
\hline \multirow[t]{2}{*}{ Board Independence } & 97.3626 & 97.2628 & 96.9636 & 100.3892 & 101.1287 & 91.3612 \\
\hline & $(.15)$ & $(.152)$ & (.1526) & $(0.112)$ & $(0.1055)$ & $(0.1516)$ \\
\hline \multirow[t]{2}{*}{ Duality } & 63.005 & 62.7803 & 62.6855 & 65.5240 & 66.1847 & 62.5891 \\
\hline & $(0.022)$ & $(0.0221)$ & $(0.0229)$ & $(0.0187)$ & $(0.0177)$ & $(0.023)$ \\
\hline \multirow[t]{2}{*}{ Foreign Assets ${ }_{\mathrm{t}-1}$} & -0.5486 & -0.5472 & -0.5099 & -1.5651 & -1.4577 & -0.2239 \\
\hline & $(0.62)$ & $(0.6257)$ & (.6685) & $(0.0231)$ & $(0.1225)$ & $(0.8245)$ \\
\hline \multirow[t]{2}{*}{ Foreign Sales $t_{t-1}$} & -0.2608 & -0.2613 & -0.2605 & -0.3024 & -0.2955 & -0.248 \\
\hline & $(.268)$ & $(.267)$ & $(0.2687)$ & $(0.2276)$ & $(0.2133)$ & $(0.2968)$ \\
\hline \multirow[t]{2}{*}{ Intercept } & -2281.33 & -2279.7 & -2281.27 & -2175.29 & -2232.52 & -2300.15 \\
\hline & $(<.0001)$ & $(<.0001)$ & $(<.0001)$ & $(<.0001)$ & $(<.0001)$ & $(<.0001)$ \\
\hline adj-R square & 0.02536 & 0.02537 & 0.02535 & 0.02673 & 0.02659 & 0.02522 \\
\hline $\mathrm{N}$ & 28347 & 28347 & 28347 & 28347 & 28347 & 28347 \\
\hline Year Fixed effects & Yes & Yes & Yes & Yes & Yes & Yes \\
\hline Clustered St errors at the country level & Yes & Yes & Yes & Yes & Yes & Yes \\
\hline
\end{tabular}


Panel C: Logit analysis of cross-border mergers

\begin{tabular}{|c|c|c|c|c|c|c|}
\hline & (1) & $(2)$ & (3) & (4) & $(5)$ & (6) \\
\hline \multirow[t]{2}{*}{ FD } & $0.6286^{* * * *}$ & & & & & \\
\hline & $(<.0001)$ & & & & & \\
\hline \multirow[t]{2}{*}{$\mathrm{FD}_{\mathrm{t}-1}$} & & $0.6009 * * *$ & & & & \\
\hline & & $(<.0001)$ & & & & \\
\hline \multirow[t]{2}{*}{$\mathrm{FD}_{\mathrm{t}-2}$} & & & $0.5896 * * *$ & & & \\
\hline & & & $(<.0001)$ & & & \\
\hline \multirow[t]{2}{*}{ \#FD } & & & & $0.1459 * * *$ & & \\
\hline & & & & $(<.0001)$ & & \\
\hline \multirow[t]{2}{*}{$\%$ FD on board } & & & & & $1.4019 * * *$ & \\
\hline & & & & & $(<.0001)$ & \\
\hline \multirow[t]{2}{*}{ FID } & & & & & & $0.5515 * * *$ \\
\hline & & & & & & $(<.0001)$ \\
\hline \multirow[t]{2}{*}{$\log (\text { Assets })_{t-1}$} & 0.261 & 0.2606 & 0.2607 & 0.2641 & 0.2616 & 0.2624 \\
\hline & $(<.0001)$ & $(<.0001)$ & $(<.0001)$ & $(<.0001)$ & $(<.0001)$ & $(<.0001)$ \\
\hline \multirow[t]{2}{*}{$\mathrm{ROA}_{\mathrm{t}-1}$} & 0.00349 & 0.00352 & 0.00353 & 0.00356 & 0.00362 & 0.00336 \\
\hline & $(0.1215)$ & $(0.1164)$ & $(0.1139)$ & $(0.1148)$ & $(0.1098)$ & $(0.1345)$ \\
\hline \multirow[t]{2}{*}{ Board Size $\mathrm{t}_{\mathrm{t}-1}$} & -0.00468 & -0.00297 & 0.00202 & -0.00766 & 0.0119 & 0.00259 \\
\hline & $(0.5052)$ & $(.6751)$ & $(0.7746)$ & $(0.2773)$ & $(0.0862)$ & $(0.7158)$ \\
\hline \multirow[t]{2}{*}{ Board Independence } & -0.1266 & -0.1284 & -0.1296 & -0.1432 & -0.1316 & -0.2486 \\
\hline & $(.1168)$ & $(.1179)$ & $(0.1170)$ & $(0.0602)$ & $(0.0903)$ & $(0.0008)$ \\
\hline \multirow[t]{2}{*}{ Duality } & 0.00833 & 0.00739 & 0.00453 & 0.0113 & 0.0135 & 0.00675 \\
\hline & $(0.8823)$ & $(0.8967)$ & $(0.9372)$ & $(0.8567)$ & $(0.8299)$ & $(0.9063)$ \\
\hline \multirow[t]{2}{*}{ Foreign Assets ${ }_{\mathrm{t}-1}$} & 0.0098 & 0.0099 & 0.00992 & 0.0100 & 0.0099 & 0.0104 \\
\hline & $(0.0138)$ & $(0.0134)$ & $(0.0136)$ & $(0.0139)$ & $(0.0144)$ & $(0.0112)$ \\
\hline \multirow[t]{2}{*}{ Foreign Sales $_{\mathrm{t}-1}$} & 0.007 & 0.00707 & 0.00713 & 0.00715 & 0.00713 & 0.00731 \\
\hline & $(.1451)$ & $(.1455)$ & $(0.1474)$ & $(0.1778)$ & $(0.1599)$ & $(0.1679)$ \\
\hline \multirow[t]{2}{*}{ Intercept } & -7.4081 & -7.4092 & -7.3875 & -7.323 & -7.4574 & -7.3281 \\
\hline & $(<.0001)$ & $(<.0001)$ & $(<.0001)$ & $(<.0001)$ & $(<.0001)$ & $(<.0001)$ \\
\hline Pseudo-R square & 0.1860 & 0.1851 & 0.1847 & 0.1836 & 0.1842 & 0.1823 \\
\hline $\mathrm{N}$ & 98708 & 98708 & 98708 & 98708 & 98708 & 98708 \\
\hline Year Fixed effects & Yes & Yes & Yes & Yes & Yes & Yes \\
\hline Clustered St errors at the country level & Yes & Yes & Yes & Yes & Yes & Yes \\
\hline
\end{tabular}




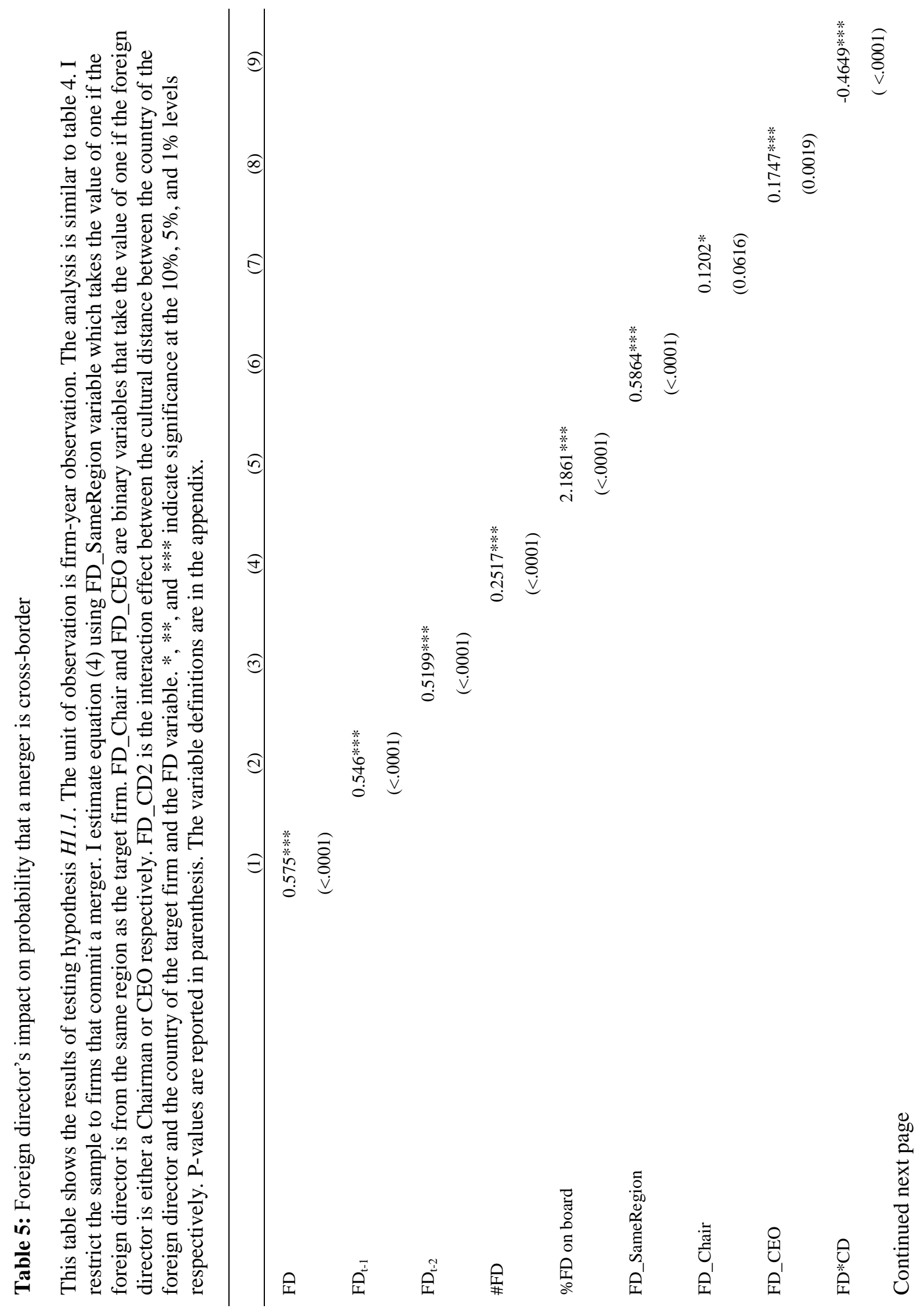




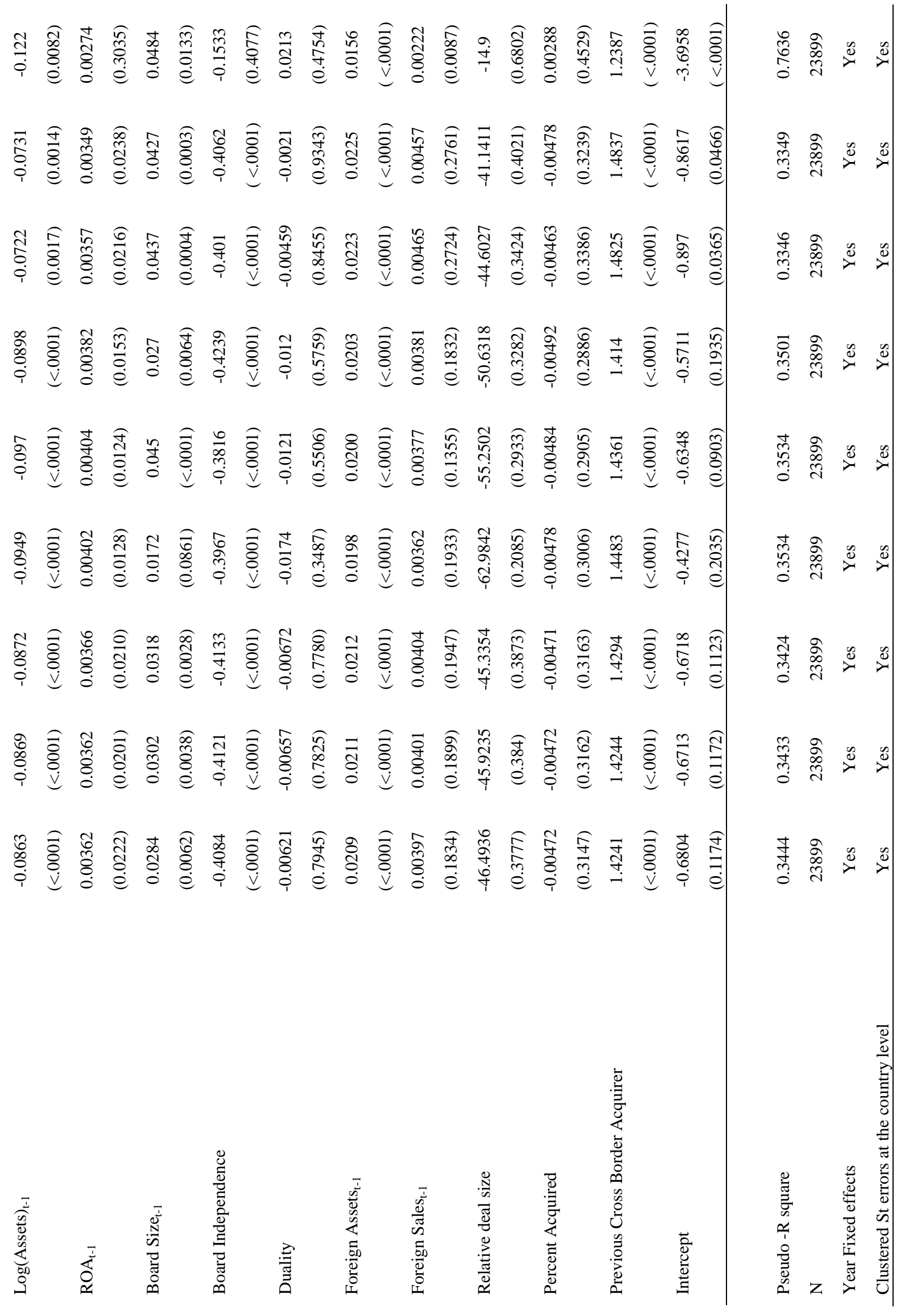


Table 6: Foreign directors and diversifying merger activity

This table tests hypothesis H1.2. Panel A reports the averages of the specified variables. Diversifying cross-border merger is a binary variable which takes the value of one if the cross-border merger is a diversifying merger and zero otherwise. Number of diversified mergers is the number of diversified crossborder mergers a firm in my sample commits to in a given year. Volume of diversified mergers is the dollar amount spent on diversified mergers in a given year. Panel B reports the logit model where the dependent variable is Diversifying cross-border merger. Panel C reports the Poisson regression model where the dependent variable is Number of diversified mergers. Panel D reports OLS estimates where the dependent variable is Volume of diversified mergers. *,**, and *** indicate significance at the $10 \%, 5 \%$, and $1 \%$ levels respectively. P-values are reported in parenthesis. The variable definitions are in the appendix.

Panel A: Diversifying mergers and foreign directors

\begin{tabular}{llll} 
& $\begin{array}{l}\text { Firms with foreign } \\
\text { directors }\end{array}$ & $\begin{array}{l}\text { firms with no foreign } \\
\text { directors }\end{array}$ & $\begin{array}{l}\text { Test } \\
\text { statistics }\end{array}$ \\
\hline Diversifying cross-border merger & 0.2849 & 0.3118 & $-3.65^{* * *}$ \\
Number of diversified mergers & 0.6918 & 0.5788 & $6.09^{* * *}$ \\
Volume of diversified mergers & 84.5289 & 46.5055 & $3.02^{* * *}$ \\
\hline
\end{tabular}


Panel B: Logit analysis of diversifying mergers

\begin{tabular}{|c|c|c|c|c|c|c|}
\hline & (1) & (2) & (3) & (4) & (5) & (6) \\
\hline FD & $\begin{array}{l}-0.1017 * * \\
(0.0283)\end{array}$ & & & & & \\
\hline $\mathrm{FD}_{\mathrm{t}-1}$ & & $\begin{array}{l}-0.0792 * \\
(0.0863)\end{array}$ & & & & \\
\hline $\mathrm{FD}_{\mathrm{t}-1}$ & & & $\begin{array}{l}-0.1089 * * \\
(0.0175)\end{array}$ & & & \\
\hline \#FD & & & & $\begin{array}{l}-0.00729 \\
(0.5099)\end{array}$ & & \\
\hline$\%$ FD on board & & & & & $\begin{array}{l}-0.0728 \\
(0.4878)\end{array}$ & \\
\hline FID & & & & & & $\begin{array}{l}-0.0939 * * \\
(0.0441)\end{array}$ \\
\hline $\log (\text { Assets })_{t-1}$ & $\begin{array}{l}0.0664 \\
(<.0001)\end{array}$ & $\begin{array}{l}0.0659 \\
(<.0001)\end{array}$ & $\begin{array}{l}0.0673 \\
(<.0001)\end{array}$ & $\begin{array}{l}0.0645 \\
(<.0001)\end{array}$ & $\begin{array}{l}0.0645 \\
(<.0001)\end{array}$ & $\begin{array}{l}0.0671 \\
(<.0001)\end{array}$ \\
\hline $\mathrm{ROA}_{\mathrm{t}-1}$ & $\begin{array}{l}-0.00446 \\
(0.003)\end{array}$ & $\begin{array}{l}-0.00447 \\
(0.003)\end{array}$ & $\begin{array}{l}-0.00447 \\
(0.003)\end{array}$ & $\begin{array}{l}-0.00445 \\
(0.0031)\end{array}$ & $\begin{array}{l}-0.00445 \\
(0.0031)\end{array}$ & $\begin{array}{l}-0.0044 \\
(0.0033)\end{array}$ \\
\hline Board Size $_{\mathrm{t}-1}$ & $\begin{array}{l}-0.0229 \\
(<.0001)\end{array}$ & $\begin{array}{l}-0.0236 \\
(<.0001)\end{array}$ & $\begin{array}{l}-0.0231 \\
(<.0001)\end{array}$ & $\begin{array}{l}-0.0243 \\
(<.0001)\end{array}$ & $\begin{array}{l}-0.0255 \\
(<.0001)\end{array}$ & $\begin{array}{l}-0.0245 \\
(<.0001)\end{array}$ \\
\hline Duality & $\begin{array}{l}0.0337 \\
(0.0202)\end{array}$ & $\begin{array}{l}0.0337 \\
(0.0202)\end{array}$ & $\begin{array}{l}0.034 \\
(0.0192)\end{array}$ & $\begin{array}{l}0.0337 \\
(0.0202)\end{array}$ & $\begin{array}{l}0.0335 \\
(0.0209)\end{array}$ & $\begin{array}{l}0.0344 \\
(0.0177)\end{array}$ \\
\hline Foreign Sales $_{\mathrm{t}-1}$ & $\begin{array}{l}0.00103 \\
(0.0022)\end{array}$ & $\begin{array}{l}0.00101 \\
(0.0024)\end{array}$ & $\begin{array}{l}0.00104 \\
(0.0021)\end{array}$ & $\begin{array}{l}0.000992 \\
(0.0026)\end{array}$ & $\begin{array}{l}0.000987 \\
(0.0027)\end{array}$ & $\begin{array}{l}0.00103 \\
(0.0021)\end{array}$ \\
\hline Previous Cross Border Acquirer & $\begin{array}{l}-0.0527 \\
(0.3581)\end{array}$ & $\begin{array}{l}-0.0535 \\
(0.3513)\end{array}$ & $\begin{array}{l}-0.0496 \\
(0.3882)\end{array}$ & $\begin{array}{l}-0.0603 \\
(0.2922)\end{array}$ & $\begin{array}{l}-0.0597 \\
(0.297)\end{array}$ & $\begin{array}{l}-0.0557 \\
(0.3311)\end{array}$ \\
\hline Intercept & $\begin{array}{l}-1.3786 \\
(<.0001)\end{array}$ & $\begin{array}{l}-1.376 \\
(<.0001)\end{array}$ & $\begin{array}{l}-1.3919 \\
(<.0001)\end{array}$ & $\begin{array}{l}-1.3725 \\
(<.0001)\end{array}$ & $\begin{array}{l}-1.3629 \\
(<.0001)\end{array}$ & $\begin{array}{l}-1.3971 \\
(<.0001)\end{array}$ \\
\hline Pseudo -R square & 0.0956 & 0.0954 & 0.0957 & 0.0952 & 0.0952 & 0.0952 \\
\hline $\mathrm{N}$ & 12199 & 12199 & 12199 & 12199 & 12199 & 12199 \\
\hline Industry fixed effects & Yes & Yes & Yes & Yes & Yes & Yes \\
\hline Year Fixed effects & Yes & Yes & Yes & Yes & Yes & Yes \\
\hline Clustered St errors at the country level & Yes & Yes & Yes & Yes & Yes & Yes \\
\hline
\end{tabular}


Panel C: Poisson analysis of diversifying mergers

\begin{tabular}{|c|c|c|c|c|c|c|}
\hline & $(1)$ & $(2)$ & (3) & (4) & $(5)$ & (6) \\
\hline \multirow[t]{2}{*}{ FD } & $-0.071 * * *$ & & & & & \\
\hline & $(0.0062)$ & & & & & \\
\hline \multirow[t]{2}{*}{$\mathrm{FD}_{\mathrm{t}-1}$} & & $-0.0519 * *$ & & & & \\
\hline & & $(0.0436)$ & & & & \\
\hline \multirow[t]{2}{*}{$\mathrm{FD}_{\mathrm{t}-1}$} & & & $-0.0604 * *$ & & & \\
\hline & & & $(0.018)$ & & & \\
\hline \multirow[t]{2}{*}{ \#FD } & & & & $0.025 * * *$ & & \\
\hline & & & & $(<.0001)$ & & \\
\hline \multirow[t]{2}{*}{$\% \mathrm{FD}$ on board } & & & & & $0.2379 * * *$ & \\
\hline & & & & & $(<.0001)$ & \\
\hline \multirow[t]{2}{*}{ FID } & & & & & & -0.0248 \\
\hline & & & & & & $(0.3208)$ \\
\hline \multirow[t]{2}{*}{$\log (\text { Assets })_{\mathrm{t}-1}$} & 0.1867 & 0.1864 & 0.1867 & 0.1802 & 0.1811 & 0.1861 \\
\hline & $(<.0001)$ & $(<.0001)$ & $(<.0001)$ & $(<.0001)$ & $(<.0001)$ & $(<.0001)$ \\
\hline \multirow[t]{2}{*}{$\mathrm{ROA}_{\mathrm{t}-1}$} & -0.0037 & -0.0037 & -0.0037 & -0.0036 & -0.0037 & -0.0037 \\
\hline & $(<.0001)$ & $(<.0001)$ & $(<.0001)$ & $(0.0001)$ & $(0.0001)$ & $(<.0001)$ \\
\hline \multirow[t]{2}{*}{ Board Size $_{\mathrm{t}-1}$} & -0.0179 & -0.0185 & -0.0184 & -0.0239 & -0.0197 & -0.0195 \\
\hline & $(<.0001)$ & $(<.0001)$ & $(<.0001)$ & $(<.0001)$ & $(<.0001)$ & $(<.0001)$ \\
\hline \multirow[t]{2}{*}{ Duality } & 0.0765 & 0.0765 & 0.0766 & 0.0743 & 0.0753 & 0.0765 \\
\hline & $(<.0001)$ & $(<.0001)$ & $(<.0001)$ & $(<.0001)$ & $(<.0001)$ & $(<.0001)$ \\
\hline \multirow[t]{2}{*}{ Foreign Sales $_{\mathrm{t}-1}$} & 0 & 0 & 0 & 0 & 0 & 0 \\
\hline & $(0.804)$ & $(0.8016)$ & $(0.8057)$ & $(0.6351)$ & $(0.7568)$ & $(0.8272)$ \\
\hline \multirow[t]{2}{*}{ Previous Cross Border Acquirer } & 0.4029 & 0.4017 & 0.4035 & 0.39 & 0.3877 & 0.3977 \\
\hline & $(<.0001)$ & $(<.0001)$ & $(<.0001)$ & $(<.0001)$ & $(<.0001)$ & $(<.0001)$ \\
\hline \multirow[t]{2}{*}{ Intercept } & -2.7428 & -2.7333 & -2.7417 & -2.5893 & -2.6239 & -2.7195 \\
\hline & $(<.0001)$ & $(<.0001)$ & $(<.0001)$ & $(<.0001)$ & $(<.0001)$ & $(<.0001)$ \\
\hline $\mathrm{N}$ & 12199 & 12199 & 12199 & 12199 & 12199 & 12199 \\
\hline Industry fixed effects & Yes & Yes & Yes & Yes & Yes & Yes \\
\hline Year Fixed effects & Yes & Yes & Yes & Yes & Yes & Yes \\
\hline Clustered St errors at the country level & Yes & Yes & Yes & Yes & Yes & Yes \\
\hline
\end{tabular}


Panel D: OLS analysis of diversifying mergers

\begin{tabular}{|c|c|c|c|c|c|c|}
\hline & $(1)$ & $(2)$ & (3) & $(4)$ & $(5)$ & (6) \\
\hline FD & $\begin{array}{l}-10.2612 \\
(0.1266)\end{array}$ & & & & & \\
\hline $\mathrm{FD}_{\mathrm{t}-1}$ & & $\begin{array}{l}-23.1349 \\
(0.2276)\end{array}$ & & & & \\
\hline $\mathrm{FD}_{\mathrm{t}-1}$ & & & $\begin{array}{l}-19.1998 \\
(0.2898)\end{array}$ & & & \\
\hline \#FD & & & & $\begin{array}{l}5.74418 \\
(0.1674)\end{array}$ & & \\
\hline$\%$ FD on board & & & & & $\begin{array}{l}10.21187 \\
(0.5296)\end{array}$ & \\
\hline FID & & & & & & $\begin{array}{c}-15.7362 \\
(0.3607)\end{array}$ \\
\hline $\log (\text { Assets })_{t-1}$ & $\begin{array}{l}27.23421 \\
(<.0001)\end{array}$ & $\begin{array}{l}27.77097 \\
(<.0001)\end{array}$ & $\begin{array}{l}27.67168 \\
(<.0001)\end{array}$ & $\begin{array}{l}25.65364 \\
(<.0001)\end{array}$ & $\begin{array}{l}26.64827 \\
(<.0001)\end{array}$ & $\begin{array}{l}27.56499 \\
(<.0001)\end{array}$ \\
\hline $\mathrm{ROA}_{\mathrm{t}-1}$ & $\begin{array}{l}-0.32267 \\
(0.2029)\end{array}$ & $\begin{array}{l}-0.33168 \\
(0.205)\end{array}$ & $\begin{array}{l}-0.32866 \\
(0.2078)\end{array}$ & $\begin{array}{l}-0.29241 \\
(0.2111)\end{array}$ & $\begin{array}{l}-0.31381 \\
(0.2055)\end{array}$ & $\begin{array}{l}-0.31556 \\
(0.2105)\end{array}$ \\
\hline Board Size $_{t-1}$ & $\begin{array}{l}5.23258 \\
(0.0907)\end{array}$ & $\begin{array}{l}5.47621 \\
(0.0774)\end{array}$ & $\begin{array}{l}5.36476 \\
(0.084)\end{array}$ & $\begin{array}{l}4.22472 \\
(0.1426)\end{array}$ & $\begin{array}{l}5.02667 \\
(0.0964)\end{array}$ & $\begin{array}{l}5.14679 \\
(0.0904)\end{array}$ \\
\hline Duality & $\begin{array}{l}-0.08527 \\
(0.1097)\end{array}$ & $\begin{array}{l}-0.08207 \\
(0.1149)\end{array}$ & $\begin{array}{l}-0.08287 \\
(0.1112)\end{array}$ & $\begin{array}{l}-0.09667 \\
(0.0901)\end{array}$ & $\begin{array}{l}-0.08915 \\
(0.0993)\end{array}$ & $\begin{array}{l}-0.08323 \\
(0.1173)\end{array}$ \\
\hline Foreign Sales $\mathrm{t}_{\mathrm{t}-1}$ & $\begin{array}{l}-10.8545 \\
(0.0109)\end{array}$ & $\begin{array}{l}-9.37059 \\
(0.0556)\end{array}$ & $\begin{array}{l}-9.55557 \\
(0.0552)\end{array}$ & $\begin{array}{l}-13.0981 \\
(0.0042)\end{array}$ & $\begin{array}{l}-12.051 \\
(0.0067)\end{array}$ & $\begin{array}{c}-10.3146 \\
(0.0238)\end{array}$ \\
\hline Previous Cross Border Acquirer & $\begin{array}{l}-322.269 \\
(0.0007) \\
\end{array}$ & $\begin{array}{l}-332.269 \\
(0.0017) \\
\end{array}$ & $\begin{array}{l}-330.509 \\
(0.0017)\end{array}$ & $\begin{array}{l}-291.754 \\
(0.0002) \\
\end{array}$ & $\begin{array}{l}-311.87 \\
(0.0005)\end{array}$ & $\begin{array}{c}-327.558 \\
(0.0005)\end{array}$ \\
\hline adj-R square & 0.009401 & 0.009502 & 0.009464 & 0.009521 & 0.009382 & 0.009435 \\
\hline $\mathrm{N}$ & 12199 & 12199 & 12199 & 12199 & 12199 & 12199 \\
\hline Industry fixed effects & Yes & Yes & Yes & Yes & Yes & Yes \\
\hline Year Fixed effects & Yes & Yes & Yes & Yes & Yes & Yes \\
\hline Clustered St errors at the country level & Yes & Yes & Yes & Yes & Yes & Yes \\
\hline
\end{tabular}


Table 7: Foreign directors and merger negotiations

This table tests hypothesis H1.3. Panel A reports the averages of the specified variables. Friendly crossborder merger is a binary variable which takes the value of one if the cross-border merger is a friendly merger and zero otherwise. Number of friendly mergers is the number of friendly cross-border mergers a firm in my sample commits to in a given year. Volume of friendly mergers is the dollar amount spent on friendly mergers in a given year. Panel B reports the logit model where the dependent variable is friendly cross-border merger. Panel $\mathrm{C}$ reports the Poisson regression model where the dependent variable is Number of friendly mergers. Panel D reports OLS estimates where the dependent variable is Volume of friendly mergers. *, **, and *** indicate significance at the $10 \%, 5 \%$, and $1 \%$ levels respectively. Pvalues are reported in parenthesis. The variable definitions are in the appendix.

Panel A: Foreign directors and the incidence of friendly mergers

\begin{tabular}{llll}
\hline & $\begin{array}{l}\text { Firms with foreign } \\
\text { directors }\end{array}$ & $\begin{array}{l}\text { firms with no foreign } \\
\text { directors }\end{array}$ & $\begin{array}{l}\text { Test } \\
\text { statistics }\end{array}$ \\
\hline friendly cross-border merger & 0.9035 & 0.9363 & $-7.47 * * *$ \\
Number of friendly mergers & 2.0015 & 1.5712 & $18.25 * * *$ \\
Volume of friendly mergers & 458.1 & 148.7 & $8.7 * * *$ \\
\hline
\end{tabular}


Panel B: Logit analysis of merger negotiations

\begin{tabular}{|c|c|c|c|c|c|c|}
\hline & (1) & (2) & (3) & (4) & (5) & (6) \\
\hline \multirow[t]{2}{*}{ FD } & -0.0934 & & & & & \\
\hline & $(0.2253)$ & & & & & \\
\hline \multirow[t]{2}{*}{$\mathrm{FD}_{\mathrm{t}-1}$} & & -0.0493 & & & & \\
\hline & & $(0.6032)$ & & & & \\
\hline \multirow[t]{2}{*}{$\mathrm{FD}_{\mathrm{t}-2}$} & & & -0.0885 & & & \\
\hline & & & $(0.35)$ & & & \\
\hline \multirow[t]{2}{*}{ \#FD } & & & & -0.0206 & & \\
\hline & & & & $(0.3021)$ & & \\
\hline \multirow[t]{2}{*}{$\%$ FD on board } & & & & & -0.028 & \\
\hline & & & & & $(0.8947)$ & \\
\hline \multirow[t]{2}{*}{ FID } & & & & & & -0.0634 \\
\hline & & & & & & $(0.5091)$ \\
\hline \multirow[t]{2}{*}{$\log (\text { Assets })_{t-1}$} & -0.1968 & -0.0441 & -0.043 & -0.0427 & -0.0448 & -0.0433 \\
\hline & $(<.0001)$ & $(0.0505)$ & $(0.0572)$ & $(0.0578)$ & $(0.047)$ & $(0.0554)$ \\
\hline \multirow[t]{2}{*}{$\mathrm{ROA}_{\mathrm{t}-1}$} & -0.00094 & 0.000934 & 0.000858 & 0.000906 & 0.000957 & 0.000978 \\
\hline & $(0.7767)$ & $(0.7906)$ & $(0.8074)$ & $(0.7962)$ & $(0.7854)$ & $(0.7801)$ \\
\hline \multirow[t]{2}{*}{ Board Size $\mathrm{t}_{\mathrm{t}-1}$} & 0.00446 & -0.00238 & -0.00175 & -0.00067 & -0.0034 & -0.00273 \\
\hline & $(0.4975)$ & $(0.759)$ & $(0.8211)$ & $(0.9338)$ & $(0.6563)$ & $(0.722)$ \\
\hline \multirow[t]{2}{*}{ Board Independence } & 0.3245 & 0.1491 & 0.1524 & 0.1541 & 0.1476 & 0.1692 \\
\hline & $(<.0001)$ & $(0.0992)$ & $(0.092)$ & $(0.0886)$ & $(0.1025)$ & $(0.0749)$ \\
\hline \multirow[t]{2}{*}{ Duality } & -0.0473 & -0.0257 & -0.0251 & -0.0245 & -0.0262 & -0.0259 \\
\hline & $(0.0217)$ & $(0.3119)$ & $(0.3236)$ & $(0.3333)$ & $(0.3025)$ & $(0.3079)$ \\
\hline \multirow[t]{2}{*}{ Foreign Sales $_{t-1}$} & 0.000678 & 0.000993 & 0.001 & 0.00105 & 0.000991 & 0.00102 \\
\hline & $(0.2064)$ & $(0.1157)$ & $(0.1179)$ & $(0.1051)$ & $(0.113)$ & $(0.1089)$ \\
\hline \multirow[t]{2}{*}{ Diversified Cross Border merger } & -0.0857 & -33.6567 & -33.6183 & -33.0958 & -33.618 & -33.3625 \\
\hline & $(0.2421)$ & $(0.0148)$ & $(0.0149)$ & $(0.0161)$ & $(0.015)$ & $(0.0156)$ \\
\hline \multirow[t]{2}{*}{ Private target } & 0.7112 & 0.0342 & 0.0342 & 0.0342 & 0.0342 & 0.0342 \\
\hline & $(<.0001)$ & $(<.0001)$ & $(<.0001)$ & $(<.0001)$ & $(<.0001)$ & $(<.0001)$ \\
\hline \multirow[t]{2}{*}{ Intercept } & 5.1019 & 0.9984 & 0.9897 & 0.9577 & 0.9999 & 0.9682 \\
\hline & $(<.0001)$ & $(0.0037)$ & $(0.004)$ & $(0.0056)$ & $(0.0036)$ & $(0.0053)$ \\
\hline Pseudo -R square & 0.0693 & 0.2829 & 0.2831 & 0.2831 & 0.2829 & 0.283 \\
\hline $\mathrm{N}$ & 12204 & 12204 & 12204 & 12204 & 12204 & 12204 \\
\hline
\end{tabular}


Panel C: Poisson analysis of merger negotiations

\begin{tabular}{|c|c|c|c|c|c|c|}
\hline & $(1)$ & $(2)$ & (3) & (4) & (5) & (6) \\
\hline \multirow[t]{2}{*}{ FD } & $0.0665^{* * *}$ & & & & & \\
\hline & $(<.0001)$ & & & & & \\
\hline \multirow[t]{2}{*}{$\mathrm{FD}_{\mathrm{t}-1}$} & & $0.0743 * * *$ & & & & \\
\hline & & $(<.0001)$ & & & & \\
\hline \multirow[t]{2}{*}{$\mathrm{FD}_{\mathrm{t}-2}$} & & & $0.074 * * *$ & & & \\
\hline & & & $(<.0001)$ & & & \\
\hline \multirow[t]{2}{*}{ \#FD } & & & & $0.0286 * * *$ & & \\
\hline & & & & $(<.0001)$ & & \\
\hline \multirow[t]{2}{*}{$\%$ FD on board } & & & & & $0.3058 * * *$ & \\
\hline & & & & & $(<.0001)$ & \\
\hline \multirow[t]{2}{*}{ FID } & & & & & & $0.0614 * * *$ \\
\hline & & & & & & $(<.0001)$ \\
\hline \multirow[t]{2}{*}{$\log (\text { Assets })_{t-1}$} & 0.0739 & 0.0735 & 0.0732 & 0.0692 & 0.0693 & 0.0732 \\
\hline & $(<.0001)$ & $(<.0001)$ & $(<.0001)$ & $(<.0001)$ & $(<.0001)$ & $(<.0001)$ \\
\hline \multirow[t]{2}{*}{$\mathrm{ROA}_{\mathrm{t}-1}$} & -0.0013 & -0.0013 & -0.0013 & -0.0011 & -0.0012 & -0.0013 \\
\hline & $(0.0206)$ & $(0.0218)$ & $(0.0223)$ & $(0.0387)$ & $(0.0335)$ & $(0.0176)$ \\
\hline \multirow[t]{2}{*}{ Board Size $_{t-1}$} & -0.0024 & -0.0024 & -0.0023 & -0.005 & -0.0002 & -0.0014 \\
\hline & $(0.113)$ & $(0.1044)$ & $(0.1231)$ & $(0.001)$ & $(0.8662)$ & $(0.3446)$ \\
\hline \multirow[t]{2}{*}{ Duality } & 0.0421 & 0.042 & 0.0419 & 0.0406 & 0.0414 & 0.0417 \\
\hline & $(<.0001)$ & $(<.0001)$ & $(<.0001)$ & $(<.0001)$ & $(<.0001)$ & $(<.0001)$ \\
\hline \multirow[t]{2}{*}{ Foreign Sales $_{\mathrm{t}-1}$} & 0 & 0 & 0 & 0 & 0 & 0 \\
\hline & $(0.4483)$ & $(0.4578)$ & $(0.4656)$ & $(0.7041)$ & $(0.5759)$ & $(0.5036)$ \\
\hline \multirow[t]{2}{*}{ Previous Cross Border Acquirer } & 0.4032 & 0.4013 & 0.4005 & 0.4035 & 0.4002 & 0.4053 \\
\hline & $(<.0001)$ & $(<.0001)$ & $(<.0001)$ & $(<.0001)$ & $(<.0001)$ & $(<.0001)$ \\
\hline \multirow[t]{2}{*}{ Intercept } & -0.7978 & -0.7894 & -0.7854 & -0.7046 & -0.7263 & -0.7944 \\
\hline & $(<.0001)$ & $(<.0001)$ & $(<.0001)$ & $(<.0001)$ & $(<.0001)$ & $(<.0001)$ \\
\hline $\mathrm{N}$ & 12204 & 12204 & 12204 & 12204 & 12204 & 12204 \\
\hline Industry fixed effects & Yes & Yes & Yes & Yes & Yes & Yes \\
\hline Year Fixed effects & Yes & Yes & Yes & Yes & Yes & Yes \\
\hline Clustered St errors at the country level & Yes & Yes & Yes & Yes & Yes & Yes \\
\hline
\end{tabular}


Panel D: OLS analysis of merger negotiations

\begin{tabular}{|c|c|c|c|c|c|c|}
\hline & $(1)$ & $(2)$ & (3) & (4) & $(5)$ & (6) \\
\hline \multirow[t]{2}{*}{ FD } & $76.5999 * *$ & & & & & \\
\hline & $(0.0121)$ & & & & & \\
\hline \multirow[t]{2}{*}{$\mathrm{FD}_{\mathrm{t}-1}$} & & 56.0272 & & & & \\
\hline & & $(0.1541)$ & & & & \\
\hline \multirow[t]{2}{*}{$\mathrm{FD}_{\mathrm{t}-2}$} & & & 65.2848 & & & \\
\hline & & & $(0.113)$ & & & \\
\hline \multirow[t]{2}{*}{ \#FD } & & & & $75.8913 * *$ & & \\
\hline & & & & $(0.0159)$ & & \\
\hline \multirow[t]{2}{*}{$\%$ FD on board } & & & & & $542.5729 * * *$ & \\
\hline & & & & & $(0.0055)$ & \\
\hline \multirow[t]{2}{*}{ FID } & & & & & & 94.8087 \\
\hline & & & & & & $(0.2402)$ \\
\hline \multirow[t]{2}{*}{$\log (\text { Assets })_{t-1}$} & 84.9523 & 85.5444 & 84.9753 & 71.4909 & 76.1802 & 83.3366 \\
\hline & $(<.0001)$ & $(<.0001)$ & $(<.0001)$ & $(0.0002)$ & $(<.0001)$ & $(<.0001)$ \\
\hline \multirow[t]{2}{*}{$\mathrm{ROA}_{\mathrm{t}-1}$} & 1.6464 & 1.643 & 1.6446 & 1.9181 & 1.8031 & 1.5911 \\
\hline & $(0.3105)$ & $(0.3115)$ & $(0.3085)$ & $(0.2663)$ & $(0.2858)$ & $(0.3183)$ \\
\hline \multirow[t]{2}{*}{ Board Size $_{\mathrm{t}-1}$} & 23.8392 & 24.3896 & 24.3218 & 15.3625 & 26.5679 & 24.8209 \\
\hline & $(0.0001)$ & $(0.0001)$ & $(0.0001)$ & $(0.0039)$ & $(<.0001)$ & $(<.0001)$ \\
\hline \multirow[t]{2}{*}{ Duality } & -22.788 & -22.8029 & -22.9142 & -26.4921 & -23.815 & -23.5459 \\
\hline & $(0.2234)$ & $(0.2251)$ & $(0.2231)$ & $(0.1824)$ & $(0.2133)$ & $(0.2088)$ \\
\hline \multirow[t]{2}{*}{ Foreign Sales $_{\mathrm{t}-1}$} & -0.0889 & -0.0838 & -0.087 & -0.1872 & -0.1372 & -0.0996 \\
\hline & $(0.2101)$ & $(0.2375)$ & $(0.2289)$ & $(0.1103)$ & $(0.1526)$ & $(0.2385)$ \\
\hline \multirow[t]{2}{*}{ Previous Cross Border Acquirer } & -48.7444 & -47.599 & -49.1517 & -49.1517 & -57.6811 & -48.2881 \\
\hline & $(0.0301)$ & $(0.0293)$ & $(0.0218)$ & $(0.0015)$ & $(0.0034)$ & $(0.0187)$ \\
\hline \multirow[t]{2}{*}{ Intercept } & -1378.59 & -1393.07 & -1381.91 & -1098.72 & -1234.7 & -1361.91 \\
\hline & $(<.0001)$ & $(<.0001)$ & $(<.0001)$ & $(0.0009)$ & $(<.0001)$ & $(<.0001)$ \\
\hline adj R squared & 0.02663 & 0.02655 & 0.02659 & 0.02953 & 0.02809 & 0.02672 \\
\hline $\mathrm{N}$ & 12204 & 12204 & 12204 & 12204 & 12204 & 12204 \\
\hline Industry fixed effects & Yes & Yes & Yes & Yes & Yes & Yes \\
\hline Year Fixed effects & Yes & Yes & Yes & Yes & Yes & Yes \\
\hline Clustered St errors at the country level & Yes & Yes & Yes & Yes & Yes & Yes \\
\hline
\end{tabular}


Panel E: Balanced logit analysis

\begin{tabular}{|c|c|c|c|c|c|c|}
\hline & $(1)$ & (2) & (3) & (4) & (5) & $(6)$ \\
\hline FD & $\begin{array}{l}0.4152 * \\
(0.0631)\end{array}$ & & & & & \\
\hline $\mathrm{FD}_{\mathrm{t}-1}$ & & $\begin{array}{l}0.4602 * * \\
(0.0415)\end{array}$ & & & & \\
\hline $\mathrm{FD}_{\mathrm{t}-2}$ & & & $\begin{array}{l}0.1439 \\
(0.5204)\end{array}$ & & & \\
\hline \#FD & & & & $\begin{array}{l}0.0372 \\
(0.4925)\end{array}$ & & \\
\hline$\% \mathrm{FD}$ on board & & & & & $\begin{array}{l}0.408 \\
(0.4504)\end{array}$ & \\
\hline FID & & & & & & $\begin{array}{l}-0.7394 * * * \\
(0.0012)\end{array}$ \\
\hline $\log (\text { Assets })_{\mathrm{t}-1}$ & $\begin{array}{l}0.0481 \\
(0.3691)\end{array}$ & $\begin{array}{l}0.0486 \\
(0.3646)\end{array}$ & $\begin{array}{l}0.055 \\
(0.2983)\end{array}$ & $\begin{array}{l}0.0513 \\
(0.3338)\end{array}$ & $\begin{array}{l}0.0555 \\
(0.2867)\end{array}$ & $\begin{array}{l}0.0879 \\
(0.092)\end{array}$ \\
\hline $\mathrm{ROA}_{\mathrm{t}-1}$ & $\begin{array}{l}0.000546 \\
(0.8698)\end{array}$ & $\begin{array}{l}0.000606 \\
(0.8557)\end{array}$ & $\begin{array}{l}0.000149 \\
(0.964)\end{array}$ & $\begin{array}{l}0.000267 \\
(0.9354)\end{array}$ & $\begin{array}{l}0.000215 \\
(0.9478)\end{array}$ & $\begin{array}{l}-0.00131 \\
(0.6872)\end{array}$ \\
\hline Board Independence & $\begin{array}{l}-0.142 \\
(0.5455)\end{array}$ & $\begin{array}{l}-0.14 \\
(0.5523)\end{array}$ & $\begin{array}{l}-0.1123 \\
(0.632)\end{array}$ & $\begin{array}{l}-0.1124 \\
(0.6302)\end{array}$ & $\begin{array}{l}-0.1092 \\
(0.6379)\end{array}$ & $\begin{array}{l}0.1071 \\
(0.6585)\end{array}$ \\
\hline Duality & $\begin{array}{l}-0.0286 \\
(0.7145)\end{array}$ & $\begin{array}{l}-0.0305 \\
(0.6964)\end{array}$ & $\begin{array}{l}-0.0238 \\
(0.7616)\end{array}$ & $\begin{array}{l}-0.023 \\
(0.7717)\end{array}$ & $\begin{array}{l}-0.0218 \\
(0.7823)\end{array}$ & $\begin{array}{l}-0.0362 \\
(0.6309)\end{array}$ \\
\hline Diversified Cross Border merger & $\begin{array}{l}0.3102 \\
(0.1653)\end{array}$ & $\begin{array}{l}0.3024 \\
(0.1774)\end{array}$ & $\begin{array}{l}0.2929 \\
(0.1851)\end{array}$ & $\begin{array}{l}0.318 \\
(0.1543)\end{array}$ & $\begin{array}{l}0.3077 \\
(0.1651)\end{array}$ & $\begin{array}{l}0.2667 \\
(0.2253)\end{array}$ \\
\hline Private target & $\begin{array}{l}0.9688 \\
(<.0001)\end{array}$ & $\begin{array}{l}0.9804 \\
(<.0001)\end{array}$ & $\begin{array}{l}0.9573 \\
(<.0001)\end{array}$ & $\begin{array}{l}0.9614 \\
(<.0001)\end{array}$ & $\begin{array}{l}0.9621 \\
(<.0001)\end{array}$ & $\begin{array}{l}0.9912 \\
(<.0001)\end{array}$ \\
\hline Percent Acquired & $\begin{array}{l}0.0276 \\
(<.0001)\end{array}$ & $\begin{array}{l}0.0275 \\
(<.0001)\end{array}$ & $\begin{array}{l}0.0272 \\
(<.0001)\end{array}$ & $\begin{array}{l}0.0273 \\
(<.0001)\end{array}$ & $\begin{array}{l}0.0272 \\
(<.0001)\end{array}$ & $\begin{array}{l}0.0279 \\
(<.0001)\end{array}$ \\
\hline Previous Cross Border Acquirer & $\begin{array}{l}-0.3506 \\
(0.2052)\end{array}$ & $\begin{array}{l}-0.3847 \\
(0.1708)\end{array}$ & $\begin{array}{l}-0.2818 \\
(0.3114)\end{array}$ & $\begin{array}{l}-0.2731 \\
(0.3171)\end{array}$ & $\begin{array}{l}-0.2762 \\
(0.314)\end{array}$ & $\begin{array}{l}-0.1682 \\
(0.5572)\end{array}$ \\
\hline Intercept & $\begin{array}{l}-2.5049 \\
(0.0023)\end{array}$ & $\begin{array}{l}-2.4999 \\
(0.0023) \\
\end{array}$ & $\begin{array}{l}-2.5115 \\
(0.0022) \\
\end{array}$ & $\begin{array}{l}-2.4589 \\
(0.0028) \\
\end{array}$ & $\begin{array}{l}-2.5242 \\
(0.002) \\
\end{array}$ & $\begin{array}{l}-2.9949 \\
(0.0003) \\
\end{array}$ \\
\hline Pseudo R squared & 0.3622 & 0.3636 & 0.3569 & 0.3572 & 0.3573 & 0.3724 \\
\hline $\mathrm{N}$ & 610 & 610 & 610 & 610 & 610 & 610 \\
\hline Year Fixed effects & Yes & Yes & Yes & Yes & Yes & Yes \\
\hline
\end{tabular}


Table 8: Foreign directors and announcement period returns

This table tests hypothesis H2.1. Panel A reports the average abnormal returns (CARs) at the merger announcement dates for the windows specified in the table. The CARs are calculated as specified in equations in the Panel A. The panel compares the averages for firms with one foreign director, multiple foreign directors, and no foreign directors. Panel B reports the effect of foreign directors on cross-border mergers abnormal returns in a multivariate analysis. The dependent variable is the CAR with the window of $(-2,+2) . * * *$, and $* * *$ indicate significance at the $10 \%, 5 \%$, and $1 \%$ levels respectively. P-values are reported in parenthesis. The variable definitions are in the appendix.

Panel A: Foreign directors and cumulative abnormal returns

$$
\begin{array}{ll}
R_{i j t}=\alpha_{i}+\beta_{i}^{m} R_{m j t}+\varepsilon_{i t} & \mathrm{t}=-131, \ldots,-31 \\
C A R_{i}^{(\mathrm{T} 1, \mathrm{~T} 2)}=\prod_{t=T_{1}}^{t=T_{2}}\left(1+\hat{\varepsilon}_{i t}\right)-1 &
\end{array}
$$

\begin{tabular}{lllllll}
\hline CAR & (1) One FD & (2) Multiple FD & (3) No FD & Test 1-3 & Test 2-3 & Test 1-2 \\
\hline$(-1,+1)$ & 0.00652 & 0.00602 & 0.0105 & -1.08 & -1.14 & 0.7516 \\
$(-2,+2)$ & 0.00858 & 0.00647 & 0.0103 & -0.32 & -0.501 & 0.94 \\
$(0,+1)$ & 0.0064 & 0.00658 & 0.0118 & -1.64 & -1.49 & -0.12 \\
$(-5,+5)$ & 0.00823 & 0.00153 & 0.00365 & 0.5 & -0.22 & $1.99^{* *}$ \\
$(0,+10)$ & 0.00449 & -0.00088 & -0.00145 & 0.68 & 0.06 & $1.66^{*}$ \\
\hline
\end{tabular}


Panel B: Regression analysis of CARs

\begin{tabular}{|c|c|c|c|c|c|c|}
\hline & $(1)$ & $(2)$ & (3) & (4) & $(5)$ & $(6)$ \\
\hline \multirow[t]{2}{*}{ FD } & $0.005943 * *$ & & & & & \\
\hline & $(0.0392)$ & & & & & \\
\hline \multirow[t]{2}{*}{$\mathrm{FD}_{\mathrm{t}-1}$} & & $0.005615^{*}$ & & & & \\
\hline & & $(0.055)$ & & & & \\
\hline \multirow[t]{2}{*}{$\mathrm{FD}_{\mathrm{t}-2}$} & & & $0.006927 * *$ & & & \\
\hline & & & $(0.0125)$ & & & \\
\hline \multirow[t]{2}{*}{ \#FD } & & & & 0.000751 & & \\
\hline & & & & $(0.2548)$ & & \\
\hline \multirow[t]{2}{*}{$\%$ FD on board } & & & & & $0.01566 * *$ & \\
\hline & & & & & $(0.0474)$ & \\
\hline \multirow[t]{2}{*}{ FID } & & & & & & 0.00253 \\
\hline & & & & & & $(0.4165)$ \\
\hline \multirow[t]{2}{*}{$\log (\text { Assets })_{t-1}$} & -0.00268 & -0.00285 & -0.00294 & -0.00247 & -0.0027 & -0.00245 \\
\hline & $(0.005)$ & $(0.0062)$ & $(0.0035)$ & $(0.0067)$ & $(0.006)$ & $(0.0093)$ \\
\hline \multirow[t]{2}{*}{ Board Size $\mathrm{t}_{\mathrm{t}-1}$} & 0.000138 & 0.000168 & 0.00013 & 0.000206 & 0.000325 & 0.000283 \\
\hline & $(0.8158)$ & $(0.7753)$ & $(0.8217)$ & $(0.7205)$ & $(0.5791)$ & $(0.6323)$ \\
\hline \multirow[t]{2}{*}{ Board Independence } & 0.004946 & 0.004853 & 0.005006 & 0.005377 & 0.005309 & 0.004632 \\
\hline & $(0.1933)$ & $(0.2209)$ & $(0.2039)$ & $(0.1479)$ & $(0.1642)$ & $(0.2496)$ \\
\hline \multirow[t]{2}{*}{ Duality } & -0.00125 & -0.00119 & -0.00118 & -0.00133 & -0.00144 & -0.00131 \\
\hline & $(0.0834)$ & $(0.1045)$ & $(0.1102)$ & $(0.0766)$ & $(0.0696)$ & $(0.0626)$ \\
\hline \multirow[t]{2}{*}{ Foreign Assets $\mathrm{t}_{\mathrm{t}-1}$} & -0.00004 & -0.00005 & -0.00005 & -0.00003 & -0.00004 & -0.00003 \\
\hline & $(0.5638)$ & $(0.4777)$ & $(0.4561)$ & $(0.6716)$ & $(0.569)$ & $(0.6727)$ \\
\hline \multirow[t]{2}{*}{ Foreign Sales $_{\mathrm{t}-1}$} & 0.00005 & 0.00004 & 0.00004 & 0.00005 & 0.00004 & 0.00005 \\
\hline & $(0.0003)$ & $(0.0002)$ & $(0.0001)$ & $(0.0002)$ & $(0.0002)$ & $(0.0008)$ \\
\hline \multirow[t]{2}{*}{ Diversified Cross Border merger } & -0.00043 & -0.00033 & -0.0006 & -0.00019 & -0.00055 & -0.00016 \\
\hline & $(0.9049)$ & $(0.9247)$ & $(0.8627)$ & $(0.9563)$ & $(0.8733)$ & $(0.9648)$ \\
\hline \multirow[t]{2}{*}{ Private target } & 0.038811 & 0.038415 & 0.038924 & 0.037432 & 0.037562 & 0.037777 \\
\hline & $(0.0003)$ & $(0.0004)$ & $(0.0003)$ & $(0.0007)$ & $(0.0007)$ & $(0.0006)$ \\
\hline \multirow[t]{2}{*}{ Percent Acquired } & -0.00019 & -0.00018 & -0.0002 & -0.00014 & -0.00018 & -0.00013 \\
\hline & $(0.1897)$ & $(0.2606)$ & $(0.1922)$ & $(0.3026)$ & $(0.2162)$ & $(0.3584)$ \\
\hline \multirow[t]{2}{*}{ Intercept } & 0.046799 & 0.022553 & 0.025842 & 0.017146 & 0.046282 & 0.038948 \\
\hline & $(0.1023)$ & $(0.4663)$ & $(0.3897)$ & $(0.5602)$ & $(0.1237)$ & $(0.165)$ \\
\hline adj $R$ squared & 0.03038 & 0.02911 & 0.02975 & 0.02831 & 0.02831 & 0.03058 \\
\hline $\mathrm{N}$ & 1158 & 1158 & 1158 & 1158 & 1158 & 1158 \\
\hline Year Fixed effects & Yes & Yes & Yes & Yes & Yes & Yes \\
\hline Clustered St errors at the country level & Yes & Yes & Yes & Yes & Yes & Yes \\
\hline
\end{tabular}


Table 9: Legal regime and accounting standards effects on CARs.

This table tests hypothesis H2.2. Panel A reports the results of a multivariate analysis of the interaction effect of foreign directors and the legal regime or the accounting standards of the target firm. Legal regime and accounting standards are drawn from La Porta et.al (1998). The dependent variable is the CAR with the window of $(-2,+2)$. Panel B reports the results of a multivariate analysis where the dependent variable is the same as in panel A. The Better legal FD and Better accounting FD variables are binary variables that assume the value of one if the acquiring firm has at least one foreign director that is from a country with a better legal regime or accounting standards respectively. *,**, and *** indicate significance at the $10 \%, 5 \%$, and $1 \%$ levels respectively. P-values are reported in parenthesis. The variable definitions are in the appendix.

Panel A: Legal regime and accounting standards and the target firm

$C A R_{i, t}^{(-2,+2)}=\alpha_{0}+\beta_{1}(F D)_{i, t}+\beta_{2}(F D * L R \text { or } A S)_{i, t}+\sum_{x=1}^{j} \gamma_{x} Z_{i, t}+e_{i, t}$

\begin{tabular}{|c|c|c|c|c|}
\hline & (1) & (2) & (3) & (4) \\
\hline FD & $0.005425^{*}$ & 0.003498 & $0.004841 *$ & $0.006091 * *$ \\
\hline & $(0.0542)$ & $(0.239)$ & $(0.076)$ & $(0.025)$ \\
\hline $\mathrm{FD} * \mathrm{LR}$ & -0.00429 & & -0.00903 & \\
\hline & $(0.4848)$ & & $(0.2745)$ & \\
\hline FD*AS & & $\begin{array}{l}0.000152 \\
(0.3958)\end{array}$ & $\begin{array}{l}0.000307 \\
(0.2824)\end{array}$ & \\
\hline FD*AS*LR & & & & $\begin{array}{l}-0.00014 * \\
(0.0717)\end{array}$ \\
\hline LR & $\begin{array}{l}0.002 \\
(0.704)\end{array}$ & & $\begin{array}{l}0.00329 \\
(0.576)\end{array}$ & $\begin{array}{l}0.0051 \\
(0.3791)\end{array}$ \\
\hline AS & & $\begin{array}{l}0.00005 \\
(0.8235)\end{array}$ & $\begin{array}{l}-0.0001 \\
(0.503)\end{array}$ & $\begin{array}{l}0.00002 \\
(0.8901)\end{array}$ \\
\hline $\log (\text { Assets })_{t-1}$ & $\begin{array}{l}-0.00283 \\
(0.0082)\end{array}$ & $\begin{array}{l}-0.00242 \\
(0.0227)\end{array}$ & $\begin{array}{l}-0.00288 \\
(0.0077)\end{array}$ & $\begin{array}{l}-0.00269 \\
(0.0094)\end{array}$ \\
\hline Board Size $_{t-1}$ & $\begin{array}{l}0.000296 \\
(0.6305)\end{array}$ & $\begin{array}{l}0.000389 \\
(0.5673)\end{array}$ & $\begin{array}{l}0.000466 \\
(0.49)\end{array}$ & $\begin{array}{l}0.000297 \\
(0.5861)\end{array}$ \\
\hline Board Independence & $\begin{array}{l}0.00383 \\
(0.2674)\end{array}$ & $\begin{array}{l}0.004153 \\
(0.2482)\end{array}$ & $\begin{array}{l}0.004736 \\
(0.2086)\end{array}$ & $\begin{array}{l}0.004045 \\
(0.2034)\end{array}$ \\
\hline Duality & $\begin{array}{l}-0.0015 \\
(0.0883)\end{array}$ & $\begin{array}{l}-0.00162 \\
(0.0793)\end{array}$ & $\begin{array}{l}-0.00152 \\
(0.0873)\end{array}$ & $\begin{array}{l}-0.00136 \\
(0.0357)\end{array}$ \\
\hline Foreign Assets $_{t-1}$ & $\begin{array}{l}-0.00005 \\
(0.5626)\end{array}$ & $\begin{array}{l}-0.00002 \\
(0.772)\end{array}$ & $\begin{array}{l}-0.00003 \\
(0.7174)\end{array}$ & $\begin{array}{l}-0.00003 \\
(0.7377)\end{array}$ \\
\hline Foreign Sales $_{\mathrm{t}-1}$ & $\begin{array}{l}0.00004 \\
(0.0003)\end{array}$ & $\begin{array}{l}0.00005 \\
(<.0001)\end{array}$ & $\begin{array}{l}0.00005 \\
(0.0001)\end{array}$ & $\begin{array}{l}0.00004 \\
(0.0002)\end{array}$ \\
\hline Diversified Cross Border merger & $\begin{array}{l}0.00027 \\
(0.9137)\end{array}$ & $\begin{array}{l}-0.00077 \\
(0.8341)\end{array}$ & $\begin{array}{l}0.00004 \\
(0.9888)\end{array}$ & $\begin{array}{l}-0.00018 \\
(0.9518)\end{array}$ \\
\hline Private target & $\begin{array}{l}0.04071 \\
(0.0003)\end{array}$ & $\begin{array}{l}0.03968 \\
(0.0013)\end{array}$ & $\begin{array}{l}0.03996 \\
(0.0008)\end{array}$ & $\begin{array}{l}0.04041 \\
(0.0002)\end{array}$ \\
\hline Percent Acquired & $\begin{array}{l}-0.00012 \\
(0.4343)\end{array}$ & $\begin{array}{l}-0.00033 \\
(0.0423)\end{array}$ & $\begin{array}{l}-0.00031 \\
(0.0645)\end{array}$ & $\begin{array}{l}-0.00028 \\
(0.0678)\end{array}$ \\
\hline Friendly merger & $\begin{array}{l}-0.02334 \\
(0.2569)\end{array}$ & $\begin{array}{l}-0.02624 \\
(0.193)\end{array}$ & $\begin{array}{l}-0.02492 \\
(0.2308)\end{array}$ & $\begin{array}{l}-0.02555 \\
(0.1938)\end{array}$ \\
\hline Previous Cross Border Acquirer & $\begin{array}{l}-0.0048 \\
(0.2466)\end{array}$ & $\begin{array}{l}-0.00332 \\
(0.3419)\end{array}$ & $\begin{array}{l}-0.00339 \\
(0.3523)\end{array}$ & $\begin{array}{l}-0.00346 \\
(0.3367)\end{array}$ \\
\hline Intercept & $\begin{array}{l}0.044904 \\
(0.1245) \\
\end{array}$ & $\begin{array}{l}0.057989 \\
(0.0471)\end{array}$ & $\begin{array}{l}0.063664 \\
(0.0316) \\
\end{array}$ & $\begin{array}{l}0.060111 \\
(0.0312) \\
\end{array}$ \\
\hline adj R squared & 0.033 & 0.03712 & 0.03726 & 0.03691 \\
\hline $\mathrm{N}$ & 1109 & 1028 & 1002 & 1054 \\
\hline Year Fixed effects & Yes & Yes & Yes & Yes \\
\hline Clustered St errors at the country level & Yes & Yes & Yes & Yes \\
\hline
\end{tabular}


Panel B: Legal regime and accounting standards of the acquiring firm

$C A R_{i, t}^{(-2,+2)}=\alpha_{0}+\beta_{1}(\text { Better Legal (accounting)FD) })_{i, t}+\sum_{x=1}^{j} \gamma_{x} Z_{i, t}+e_{i, t}$

\begin{tabular}{lll}
\hline & $(1)$ & $(2)$ \\
\hline Better legal FD & $0.008247^{*}$ & \\
Better accounting FD & $(0.0892)$ & $0.008923^{*}$ \\
Log(Assets) $\mathrm{t}_{-1}$ & & $(0.0524)$ \\
& & -0.00505 \\
Board Size ${ }_{\mathrm{t}-1}$ & -0.00527 & $(0.0019)$ \\
& $(0.0013)$ & 0.000367 \\
Board Independence & 0.000371 & $(0.4751)$ \\
& $(0.4593)$ & 0.001337 \\
Duality & 0.001527 & $(0.7302)$ \\
& $(0.6915)$ & -0.00025 \\
Percent Acquired & -0.00033 & $(0.6897)$ \\
Previous Cross Border Acquirer & $(0.5356)$ & -0.00017 \\
Intercept & -0.00018 & $(0.1928)$ \\
& $(0.166)$ & -0.0036 \\
adj R squared & -0.00348 & $(0.3295)$ \\
Y & $(0.337)$ & 0.101639 \\
Clustered st errors at the country level & 0.104952 & $(0.0008)$ \\
\hline
\end{tabular}


Table 10: Foreign director's impact on target type in cross-border mergers

This table tests H3.1. Panel A reports some univariate analyses. Private target is a binary variable that equals to one if the cross-border merger involves a privately-held target and zero otherwise. Number of private targets is the number of cross-border deals that involve a privately held-target in a given year. Volume of mergers with private targets is the dollar volume of cross-border mergers that involve privately-held targets in a given year and zero otherwise. Panel B reports the results of a Logit model where the dependent variable is Private target. Panel $\mathrm{C}$ reports the results of Poisson model where the dependent variable is Number of private targets. Panel D reports the results of OLS model where the dependent variable is Volume of mergers with private targets. *,**, and *** indicate significance at the $10 \%, 5 \%$, and $1 \%$ levels respectively. P-values are reported in parenthesis. The variable definitions are in the appendix.

Panel A: Foreign directors and private targets

\begin{tabular}{llll}
\hline & $\begin{array}{l}\text { Firms with foreign } \\
\text { directors }\end{array}$ & $\begin{array}{l}\text { firms with no foreign } \\
\text { directors }\end{array}$ & $\begin{array}{l}\text { Test } \\
\text { statistics }\end{array}$ \\
\hline Private Target & 0.34 & 0.4427 & $-13.14^{* * *}$ \\
Number of private targets & 0.776 & 0.7368 & $2.33^{* *}$ \\
Volume of mergers with private targets & 47.0138 & 28.4876 & $6.59 * * *$ \\
\hline
\end{tabular}


Panel B: Logit analysis of target type

\begin{tabular}{|c|c|c|c|c|c|c|}
\hline & $(1)$ & $(2)$ & (3) & (4) & $(5)$ & $(6)$ \\
\hline FD & $\begin{array}{l}-0.0131 \\
(0.7675)\end{array}$ & & & & & \\
\hline $\mathrm{FD}_{\mathrm{t}-1}$ & & $\begin{array}{l}-0.00968 \\
(0.8263)\end{array}$ & & & & \\
\hline $\mathrm{FD}_{\mathrm{t}-2}$ & & & $\begin{array}{l}-0.0201 \\
(0.6483)\end{array}$ & & & \\
\hline \#FD & & & & $\begin{array}{l}0.00337 \\
(0.7548)\end{array}$ & & \\
\hline$\% \mathrm{FD}$ on board & & & & & $\begin{array}{l}0.000024 \\
(0.9998)\end{array}$ & \\
\hline FID & & & & & & $\begin{array}{l}0.0258 \\
(0.5703)\end{array}$ \\
\hline $\log (\text { Assets })_{\mathrm{t}-1}$ & $\begin{array}{l}-0.2347 \\
(<.0001)\end{array}$ & $\begin{array}{l}-0.2348 \\
(<.0001)\end{array}$ & $\begin{array}{l}-0.2344 \\
(<.0001)\end{array}$ & $\begin{array}{l}-0.2358 \\
(<.0001)\end{array}$ & $\begin{array}{l}-0.2352 \\
(<.0001)\end{array}$ & $\begin{array}{l}-0.2363 \\
(<.0001)\end{array}$ \\
\hline $\mathrm{ROA}_{\mathrm{t}-1}$ & $\begin{array}{l}0.00401 \\
(0.015)\end{array}$ & $\begin{array}{l}0.00401 \\
(0.015)\end{array}$ & $\begin{array}{l}0.00401 \\
(0.015)\end{array}$ & $\begin{array}{l}0.00403 \\
(0.0146)\end{array}$ & $\begin{array}{l}0.00402 \\
(0.0149)\end{array}$ & $\begin{array}{l}0.00401 \\
(0.0149)\end{array}$ \\
\hline Board Size $t_{-1}$ & $\begin{array}{l}-0.0141 \\
(0.0062)\end{array}$ & $\begin{array}{l}-0.0142 \\
(0.0056)\end{array}$ & $\begin{array}{l}-0.014 \\
(0.0061)\end{array}$ & $\begin{array}{l}-0.0149 \\
(0.0046)\end{array}$ & $\begin{array}{l}-0.0145 \\
(0.0041)\end{array}$ & $\begin{array}{l}-0.0147 \\
(0.0037)\end{array}$ \\
\hline Duality & $\begin{array}{l}0.0155 \\
(0.2962)\end{array}$ & $\begin{array}{l}0.0155 \\
(0.296)\end{array}$ & $\begin{array}{l}0.0155 \\
(0.2946)\end{array}$ & $\begin{array}{l}0.0153 \\
(0.3013)\end{array}$ & $\begin{array}{l}0.0155 \\
(0.2965)\end{array}$ & $\begin{array}{l}0.0153 \\
(0.3031)\end{array}$ \\
\hline Foreign Sales $\mathrm{t}_{\mathrm{t}-1}$ & $\begin{array}{l}0.000307 \\
(0.4981)\end{array}$ & $\begin{array}{l}0.000306 \\
(0.499)\end{array}$ & $\begin{array}{l}0.00031 \\
(0.4962)\end{array}$ & $\begin{array}{l}0.000295 \\
(0.5078)\end{array}$ & $\begin{array}{l}0.000302 \\
(0.5016)\end{array}$ & $\begin{array}{l}0.000292 \\
(0.5107)\end{array}$ \\
\hline Previous Cross Border Acquirer & $\begin{array}{l}0.1509 \\
(0.0062)\end{array}$ & $\begin{array}{l}0.1507 \\
(0.0064)\end{array}$ & $\begin{array}{l}0.152 \\
(0.006)\end{array}$ & $\begin{array}{l}0.1489 \\
(0.0069)\end{array}$ & $\begin{array}{l}0.1497 \\
(0.0067)\end{array}$ & $\begin{array}{l}0.1479 \\
(0.0073)\end{array}$ \\
\hline Intercept & $\begin{array}{l}2.7908 \\
(<.0001)\end{array}$ & $\begin{array}{l}2.7915 \\
(<.0001)\end{array}$ & $\begin{array}{l}2.7864 \\
(<.0001)\end{array}$ & $\begin{array}{l}2.8059 \\
(<.0001)\end{array}$ & $\begin{array}{l}2.7953 \\
(<.0001)\end{array}$ & $\begin{array}{l}2.8091 \\
(<.0001)\end{array}$ \\
\hline Pseudo -R square & 0.1564 & 0.1564 & 0.1564 & 0.1564 & 0.1564 & 0.1564 \\
\hline $\mathrm{N}$ & 12199 & 12199 & 12199 & 12199 & 12199 & 12199 \\
\hline Industry fixed effects & Yes & Yes & Yes & Yes & Yes & Yes \\
\hline Year Fixed effects & Yes & Yes & Yes & Yes & Yes & Yes \\
\hline
\end{tabular}


Panel C: Poisson analysis of target type

\begin{tabular}{|c|c|c|c|c|c|c|}
\hline & $(1)$ & $(2)$ & (3) & (4) & $(5)$ & $(6)$ \\
\hline \multirow[t]{2}{*}{ FD } & $0.1085^{* * *}$ & & & & & \\
\hline & $(<.0001)$ & & & & & \\
\hline \multirow[t]{2}{*}{$\mathrm{FD}_{\mathrm{t}-1}$} & & $0.1173 * * *$ & & & & \\
\hline & & $(<.0001)$ & & & & \\
\hline \multirow[t]{2}{*}{$\mathrm{FD}_{\mathrm{t}-2}$} & & & $0.1169 * * *$ & & & \\
\hline & & & $(<.0001)$ & & & \\
\hline \multirow[t]{2}{*}{ \#FD } & & & & $0.034 * * *$ & & \\
\hline & & & & $(<.0001)$ & & \\
\hline \multirow[t]{2}{*}{$\%$ FD on board } & & & & & $0.3188 * * *$ & \\
\hline & & & & & $(<.0001)$ & \\
\hline \multirow[t]{2}{*}{ FID } & & & & & & $0.1059 * * *$ \\
\hline & & & & & & $(<.0001)$ \\
\hline \multirow[t]{2}{*}{$\log (\text { Assets })_{t-1}$} & -0.0378 & -0.0384 & -0.0388 & -0.0406 & -0.0406 & -0.039 \\
\hline & $(<.0001)$ & $(<.0001)$ & $(<.0001)$ & $(<.0001)$ & $(<.0001)$ & $(<.0001)$ \\
\hline \multirow[t]{2}{*}{$\mathrm{ROA}_{\mathrm{t}-1}$} & 0.0013 & 0.0013 & 0.0013 & 0.0014 & 0.0014 & 0.0012 \\
\hline & $(0.1095)$ & $(0.1002)$ & $(0.0975)$ & $(0.0795)$ & $(0.0863)$ & $(0.1189)$ \\
\hline \multirow[t]{2}{*}{ Board Size } & -0.0147 & -0.0147 & -0.0145 & -0.0171 & -0.0115 & -0.0132 \\
\hline & $(<.0001)$ & $(<.0001)$ & $(<.0001)$ & $(<.0001)$ & $(<.0001)$ & $(<.0001)$ \\
\hline \multirow[t]{2}{*}{ Duality } & 0.0511 & 0.051 & 0.0509 & 0.0498 & 0.0508 & 0.0505 \\
\hline & $(<.0001)$ & $(<.0001)$ & $(<.0001)$ & $(<.0001)$ & $(<.0001)$ & $(<.0001)$ \\
\hline \multirow[t]{2}{*}{ Foreign Sales ${ }_{t-1}$} & 0.0003 & 0.0003 & 0.0003 & 0.0003 & 0.0003 & 0.0003 \\
\hline & $(0.0192)$ & $(0.0201)$ & $(0.0207)$ & $(0.0416)$ & $(0.025)$ & $(0.0246)$ \\
\hline \multirow[t]{2}{*}{ Previous Cross Border Acquirer } & 0.5334 & 0.5312 & 0.5305 & 0.5365 & 0.5337 & 0.5368 \\
\hline & $(<.0001)$ & $(<.0001)$ & $(<.0001)$ & $(<.0001)$ & $(<.0001)$ & $(<.0001)$ \\
\hline \multirow[t]{2}{*}{ Intercept } & 0.1498 & 0.16 & 0.1662 & 0.2109 & 0.1845 & 0.1561 \\
\hline & $(0.2969)$ & $(0.2655)$ & $(0.248)$ & $(0.1435)$ & $(0.199)$ & $(0.2776)$ \\
\hline $\mathrm{N}$ & 12199 & 12199 & 12199 & 12199 & 12199 & 12199 \\
\hline Industry fixed effects & Yes & Yes & Yes & Yes & Yes & Yes \\
\hline Year Fixed effects & Yes & Yes & Yes & Yes & Yes & Yes \\
\hline
\end{tabular}


Panel D: OLS analysis of target type

\begin{tabular}{|c|c|c|c|c|c|c|}
\hline & $(1)$ & $(2)$ & (3) & (4) & (5) & $(6)$ \\
\hline \multirow[t]{2}{*}{ FD } & $8.26341 * *$ & & & & & \\
\hline & $(0.0382)$ & & & & & \\
\hline \multirow[t]{2}{*}{$\mathrm{FD}_{\mathrm{t}-1}$} & & 4.09267 & & & & \\
\hline & & $(0.3104)$ & & & & \\
\hline \multirow[t]{2}{*}{$\mathrm{FD}_{\mathrm{t}-2}$} & & & 1.95624 & & & \\
\hline & & & $(0.6274)$ & & & \\
\hline \multirow[t]{2}{*}{ \#FD } & & & & $2.20591 * *$ & & \\
\hline & & & & $(0.0131)$ & & \\
\hline \multirow[t]{2}{*}{$\%$ FD on board } & & & & & $18.32916^{* *}$ & \\
\hline & & & & & $(0.0171)$ & \\
\hline \multirow[t]{2}{*}{ FID } & & & & & & $5.11548^{*}$ \\
\hline & & & & & & $(0.0748)$ \\
\hline \multirow[t]{2}{*}{$\log (\text { Assets })_{\mathrm{t}-1}$} & 11.17943 & 11.31808 & 11.39635 & 11.01458 & 11.09435 & 11.25043 \\
\hline & $(<.0001)$ & $(<.0001)$ & $(<.0001)$ & $(<.0001)$ & $(<.0001)$ & $(<.0001)$ \\
\hline \multirow[t]{2}{*}{$\mathrm{ROA}_{\mathrm{t}-1}$} & 0.07955 & 0.078 & 0.07664 & 0.08522 & 0.08245 & 0.07484 \\
\hline & $(0.5214)$ & $(0.5301)$ & $(0.5408)$ & $(0.492)$ & $(0.508)$ & $(0.5497)$ \\
\hline \multirow[t]{2}{*}{ Board Size $\mathrm{t}_{-1}$} & -0.82563 & -0.72741 & -0.68091 & -0.94521 & -0.61046 & -0.68974 \\
\hline & $(0.0828)$ & $(0.1033)$ & $(0.1271)$ & $(0.0385)$ & $(0.1751)$ & $(0.1213)$ \\
\hline \multirow[t]{2}{*}{ Foreign Sales $_{\mathrm{t}-1}$} & -0.01117 & -0.0101 & -0.00959 & -0.01246 & -0.01137 & -0.01059 \\
\hline & $(0.5143)$ & $(0.5315)$ & $(0.5584)$ & $(0.4491)$ & $(0.4815)$ & $(0.5218)$ \\
\hline \multirow[t]{2}{*}{ Previous Cross Border Acquirer } & -9.25314 & -8.94696 & -8.7489 & -9.03839 & -9.0475 & -8.99405 \\
\hline & $(0.1183)$ & $(0.1336)$ & $(0.1432)$ & $(0.1316)$ & $(0.1283)$ & $(0.1337)$ \\
\hline \multirow[t]{2}{*}{ Intercept } & -124.193 & -126.819 & -128.273 & -120.792 & -123.713 & -125.832 \\
\hline & $(<.0001)$ & $(<.0001)$ & $(<.0001)$ & $(<.0001)$ & $(<.0001)$ & $(<.0001)$ \\
\hline adj-R square & 0.01162 & 0.01147 & 0.01143 & 0.01169 & 0.01161 & 0.0115 \\
\hline $\mathrm{N}$ & 12199 & 12199 & 12199 & 12199 & 12199 & 12199 \\
\hline Industry fixed effects & Yes & Yes & Yes & Yes & Yes & Yes \\
\hline Year Fixed effects & Yes & Yes & Yes & Yes & Yes & Yes \\
\hline Clustered St errors at the country level & Yes & Yes & Yes & Yes & Yes & Yes \\
\hline
\end{tabular}


Table 11: The effect of foreign directors on choice of target

This table test H3.2. The dependent variable is the target firm's Market-to-Book ratio one year before the merger. All observations involve cross-border deals. *,**, and *** indicate significance at the 10\%, 5\%, and $1 \%$ levels respectively. P-values are reported in parenthesis. The variable definitions are in the appendix.

\begin{tabular}{|c|c|c|c|c|c|c|}
\hline & $(1)$ & $(2)$ & (3) & (4) & $(5)$ & $(6)$ \\
\hline \multirow[t]{2}{*}{ FD } & $-1.67475^{*}$ & & & & & \\
\hline & $(0.0857)$ & & & & & \\
\hline \multirow[t]{2}{*}{$\mathrm{FD}_{\mathrm{t}-1}$} & & $-1.5158 *$ & & & & \\
\hline & & $(0.0544)$ & & & & \\
\hline \multirow[t]{2}{*}{$\mathrm{FD}_{\mathrm{t}-2}$} & & & $-1.4998 * *$ & & & \\
\hline & & & $(0.0279)$ & & & \\
\hline \multirow[t]{2}{*}{ \#FD } & & & & -0.01117 & & \\
\hline & & & & $(0.9374)$ & & \\
\hline \multirow[t]{2}{*}{$\%$ FD on board } & & & & & -1.38452 & \\
\hline & & & & & $(0.3116)$ & \\
\hline \multirow[t]{2}{*}{ FID } & & & & & & -2.20783 \\
\hline & & & & & & $(0.3258)$ \\
\hline \multirow[t]{2}{*}{$\log (\text { Assets })_{\mathrm{t}-1}$} & 0.05163 & 0.05668 & 0.06697 & -0.00071 & 0.03466 & 0.10116 \\
\hline & $(0.8365)$ & $(0.8207)$ & $(0.7888)$ & $(0.9977)$ & $(0.8918)$ & $(0.704)$ \\
\hline \multirow[t]{2}{*}{$\mathrm{ROA}_{\mathrm{t}-1}$} & 0.01678 & 0.01665 & 0.01607 & 0.017 & 0.01668 & 0.01847 \\
\hline & $(0.6568)$ & $(0.6592)$ & $(0.6682)$ & $(0.6488)$ & $(0.6549)$ & $(0.634)$ \\
\hline \multirow[t]{2}{*}{ Board Size $_{\mathrm{t}-1}$} & 0.64148 & 0.63682 & 0.63442 & 0.61175 & 0.60463 & 0.62843 \\
\hline & $(0.0884)$ & $(0.0872)$ & $(0.0863)$ & $(0.098)$ & $(0.0929)$ & $(0.0955)$ \\
\hline \multirow[t]{2}{*}{ Board Independence } & -2.55069 & -2.55703 & -2.54059 & -2.57226 & -2.60738 & -1.89775 \\
\hline & $(0.0182)$ & $(0.0186)$ & $(0.0187)$ & $(0.0198)$ & $(0.0192)$ & $(0.0075)$ \\
\hline \multirow[t]{2}{*}{ Duality } & -0.48311 & -0.48484 & -0.4866 & -0.49899 & -0.49499 & -0.48783 \\
\hline & $(0.2268)$ & $(0.2269)$ & $(0.2273)$ & $(0.2241)$ & $(0.2226)$ & $(0.2254)$ \\
\hline \multirow[t]{2}{*}{ Foreign Sales $_{t-1}$} & -0.00541 & -0.00543 & -0.00544 & -0.00639 & -0.00601 & -0.00448 \\
\hline & $(0.5508)$ & $(0.5536)$ & $(0.556)$ & $(0.5167)$ & $(0.5251)$ & $(0.5753)$ \\
\hline \multirow[t]{2}{*}{ Relative deal size } & -412.934 & -412.915 & -407.198 & -421.2 & -403.09 & -381.001 \\
\hline & $(0.5274)$ & $(0.5277)$ & $(0.5329)$ & $(0.5152)$ & $(0.5307)$ & $(0.5379)$ \\
\hline \multirow[t]{2}{*}{ Percent Acquired } & 0.04082 & 0.04076 & 0.04042 & 0.04035 & 0.04083 & 0.04201 \\
\hline & $(0.3971)$ & $(0.3973)$ & $(0.3993)$ & $(0.4002)$ & $(0.3968)$ & $(0.3973)$ \\
\hline \multirow[t]{2}{*}{ Previous Cross Border Acquirer } & 0.97666 & 0.9959 & 1.01654 & 0.88587 & 0.92175 & 0.89524 \\
\hline & $(0.2989)$ & $(0.2885)$ & $(0.2729)$ & $(0.3184)$ & $(0.3125)$ & $(0.3248)$ \\
\hline \multirow[t]{2}{*}{ Intercept } & -2.90782 & -2.98459 & -3.50278 & -1.79352 & -2.51454 & -3.77345 \\
\hline & $(0.4611)$ & $(0.4495)$ & $(0.3764)$ & $(0.6553)$ & $(0.5424)$ & $(0.4011)$ \\
\hline adj $R$ squared & 0.02923 & 0.02919 & 0.02919 & 0.029 & 0.02903 & 0.02943 \\
\hline $\mathrm{N}$ & 1719 & 1719 & 1719 & 1719 & 1719 & 1719 \\
\hline Year Fixed effects & Yes & Yes & Yes & Yes & Yes & Yes \\
\hline Industry fixed effects & Yes & Yes & Yes & Yes & Yes & Yes \\
\hline Clustered St errors at the country level & Yes & Yes & Yes & Yes & Yes & Yes \\
\hline
\end{tabular}


Table 12: Foreign director's impact on cross-border merger price

This table test H4.1. The dependent variable is the value of the transaction of the merger over the market capitalization of the target firm one year before the merger. All observations involve cross-border deals. $*, * *$, and $* * *$ indicate significance at the $10 \%, 5 \%$, and $1 \%$ levels respectively. P-values are reported in parenthesis. The variable definitions are in the appendix.

\begin{tabular}{|c|c|c|c|c|c|c|}
\hline & (1) & (2) & (3) & (4) & (5) & (6) \\
\hline \multirow[t]{2}{*}{ FD } & $-264.84 *$ & & & & & \\
\hline & $(0.061)$ & & & & & \\
\hline \multirow[t]{2}{*}{$\mathrm{FD}_{\mathrm{t}-1}$} & & $-258.369^{*}$ & & & & \\
\hline & & $(0.0653)$ & & & & \\
\hline \multirow[t]{2}{*}{$\mathrm{FD}_{\mathrm{t}-1}$} & & & $-265.87 * *$ & & & \\
\hline & & & $(0.0414)$ & & & \\
\hline \multirow[t]{2}{*}{ \#FD } & & & & $-48.6724 *$ & & \\
\hline & & & & $(0.0684)$ & & \\
\hline \multirow[t]{2}{*}{$\% \mathrm{FD}$ on board } & & & & & -386.73 & \\
\hline & & & & & $(0.2623)$ & \\
\hline \multirow[t]{2}{*}{ FID } & & & & & & $-213.461^{*}$ \\
\hline & & & & & & $(0.0589)$ \\
\hline \multirow[t]{2}{*}{$\log (\text { Assets })_{t-1}$} & 31.2614 & 32.6118 & 35.2825 & 41.2996 & 22.3254 & 30.1257 \\
\hline & $(0.1654)$ & $(0.1434)$ & $(0.1111)$ & $(0.1075)$ & $(0.323)$ & $(0.1692)$ \\
\hline \multirow[t]{2}{*}{ Board Independence } & -361.672 & -363.099 & -363.35 & -363.813 & -374.01 & -329.784 \\
\hline & $(0.178)$ & $(0.1772)$ & $(0.1793)$ & $(0.1753)$ & $(0.1653)$ & $(0.2251)$ \\
\hline \multirow[t]{2}{*}{ Duality } & 33.2112 & 33.2394 & 32.7618 & 28.4258 & 28.0034 & 27.8406 \\
\hline & $(0.0557)$ & $(0.0545)$ & $(0.0554)$ & $(0.1042)$ & $(0.1073)$ & $(0.0983)$ \\
\hline \multirow[t]{2}{*}{ Foreign Assets $\mathrm{t}_{\mathrm{t}-1}$} & 2.0851 & 2.0331 & 2.069 & 1.894 & 1.9526 & 2.0166 \\
\hline & $(0.2243)$ & $(0.2389)$ & $(0.2288)$ & $(0.2831)$ & $(0.2574)$ & $(0.2454)$ \\
\hline \multirow[t]{2}{*}{ Foreign Sales $_{\mathrm{t}-1}$} & 0.2064 & 0.2227 & 0.2315 & 0.1215 & 0.1085 & 0.2465 \\
\hline & $(0.7395)$ & $(0.7252)$ & $(0.7141)$ & $(0.8328)$ & $(0.8524)$ & $(0.6874)$ \\
\hline \multirow[t]{2}{*}{ Percent Acquired } & 19.2561 & 19.2567 & 19.2181 & 19.5245 & 19.3472 & 19.3141 \\
\hline & $(<.0001)$ & $(<.0001)$ & $(<.0001)$ & $(<.0001)$ & $(<.0001)$ & $(<.0001)$ \\
\hline \multirow[t]{2}{*}{ Previous Cross Border Acquirer } & 223.1293 & 236.0966 & 241.323 & 224.686 & 230.1895 & 222.1893 \\
\hline & $(0.1381)$ & $(0.1267)$ & $(0.1226)$ & $(0.1362)$ & $(0.1304)$ & $(0.1418)$ \\
\hline \multirow[t]{2}{*}{ Intercept } & -651.118 & -689.137 & -753.513 & -805.624 & -512.945 & -621.784 \\
\hline & $(0.2263)$ & $(0.212)$ & $(0.1766)$ & $(0.1748)$ & $(0.3448)$ & $(0.2289)$ \\
\hline adj R squared & 0.3489 & 0.3486 & 0.3489 & 0.3477 & 0.3462 & 0.3472 \\
\hline $\mathrm{N}$ & 907 & 907 & 907 & 907 & 907 & 907 \\
\hline Year Fixed effects & Yes & Yes & Yes & Yes & Yes & Yes \\
\hline Industry fixed effects & Yes & Yes & Yes & Yes & Yes & Yes \\
\hline Country fixed effects & Yes & Yes & Yes & Yes & Yes & Yes \\
\hline
\end{tabular}


Table 13: Analysis of foreign director's impact on the method of payment in cross-border mergers

This table tests $H 4.2 a$ and $H 4.2 b$. Panel A reports some univariate tests. D_Cash is a dummy variable that equals to one if the deal is a $100 \%$ finance with cash and zero otherwise. \%Cash is the percentage of cash in the merger transaction payment package. D_Mixed is a dummy variable that equals to one if the deal is finance by a mixed ratio of cash and equity. D_Equity is a dummy variable that equals to one if the deal is a $100 \%$ finance with equity and zero otherwise. Panel B reports the results of a logit analysis where the dependent variable is D_Cash. Panel C reports the results of an OLS analysis where the dependent variable is $\%$ Cash. All observations involve cross-border deals. $*$, **, and $* * *$ indicate significance at the $10 \%, 5 \%$, and $1 \%$ levels respectively. P-values are reported in parenthesis. The variable definitions are in the appendix.

Panel A: Foreign directors and the method of payment

\begin{tabular}{lccc}
\hline & Firms with foreign directors & firms with no foreign directors & Test statistics \\
\hline D_Cash & 0.8015 & 0.757 & $6.67 * * *$ \\
\% Cash & 0.8763 & 0.8561 & $4.19^{* * *}$ \\
D_Mixed & 0.1244 & 0.1676 & $-7.59^{* * *}$ \\
D_Equity & 0.0676 & 0.0699 & -0.57 \\
\hline
\end{tabular}


Panel B: Logit analysis of method of payment

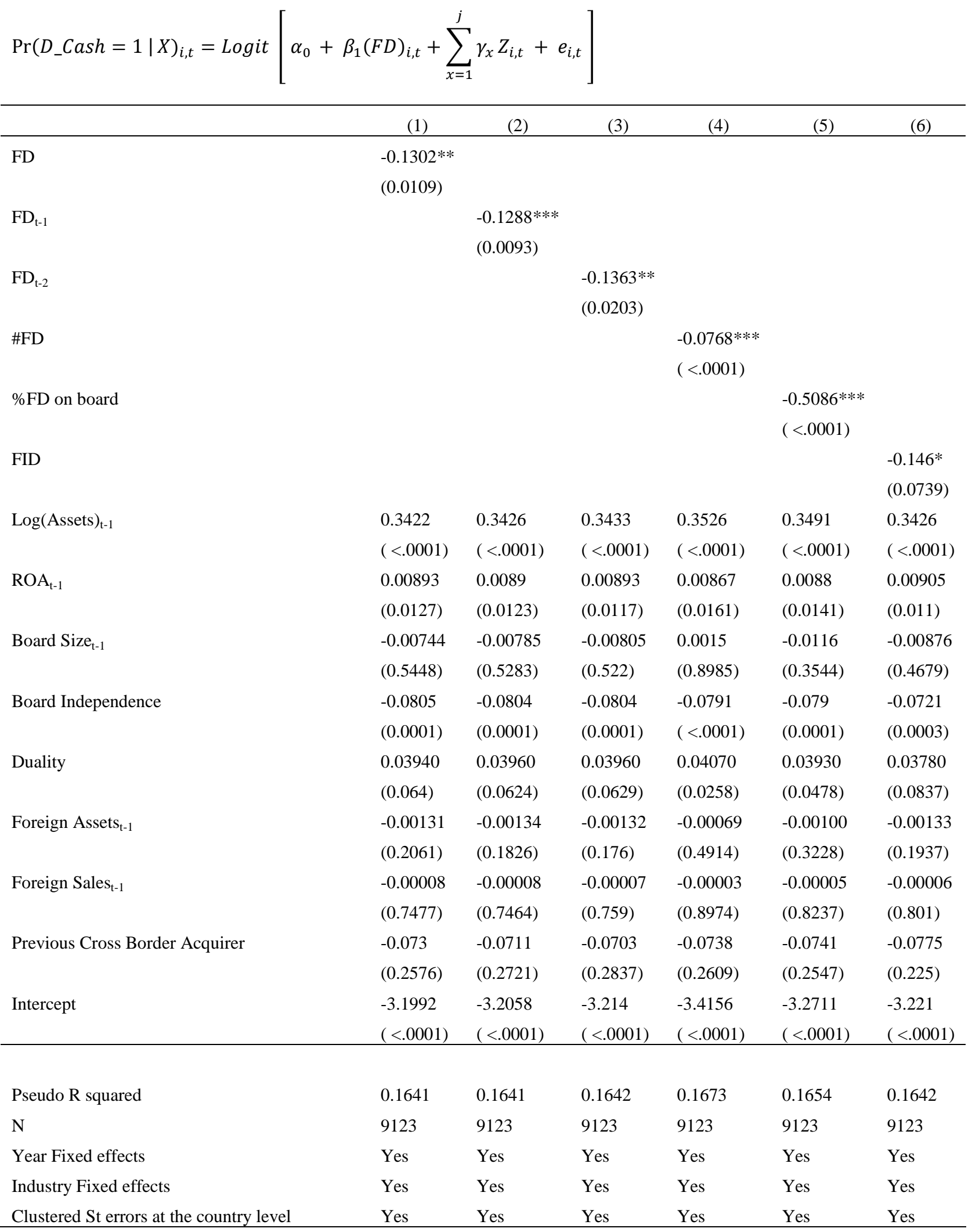


Panel C: Tobit analysis of method of payment

$$
\% \text { Cash }=\alpha_{0}+\beta_{1}(F D)_{i, t}+\sum_{x=1}^{j} \gamma_{x} Z_{i, t}+e_{i, t}
$$

\begin{tabular}{|c|c|c|c|c|c|c|}
\hline & $(1)$ & $(2)$ & $(3)$ & (4) & (5) & (6) \\
\hline FD & $\begin{array}{l}-0.02 * * * \\
(0.0006)\end{array}$ & & & & & \\
\hline $\mathrm{FD}_{\mathrm{t}-1}$ & & $\begin{array}{l}-0.02 * * * \\
(0.0002)\end{array}$ & & & & \\
\hline $\mathrm{FD}_{\mathrm{t}-2}$ & & & $\begin{array}{l}-0.019 * * * \\
(0.0002)\end{array}$ & & & \\
\hline \#FD & & & & $\begin{array}{l}-0.009 * * * \\
(<.0001)\end{array}$ & & \\
\hline$\% \mathrm{FD}$ on board & & & & & $\begin{array}{l}-0.07 * * * \\
(<.0001)\end{array}$ & \\
\hline FID & & & & & & $\begin{array}{l}-0.01401 \\
(0.1837)\end{array}$ \\
\hline $\log (\text { Assets })_{t-1}$ & $\begin{array}{l}0.033045 \\
(<.0001)\end{array}$ & $\begin{array}{l}0.033005 \\
(<.0001)\end{array}$ & $\begin{array}{l}0.03306 \\
(<.0001)\end{array}$ & $\begin{array}{l}0.034062 \\
(<.0001)\end{array}$ & $\begin{array}{l}0.033836 \\
(<.0001)\end{array}$ & $\begin{array}{l}0.032806 \\
(<.0001)\end{array}$ \\
\hline $\mathrm{ROA}_{\mathrm{t}-1}$ & $\begin{array}{l}0.002323 \\
(<.0001)\end{array}$ & $\begin{array}{l}0.002323 \\
(<.0001)\end{array}$ & $\begin{array}{l}0.002325 \\
(<.0001)\end{array}$ & $\begin{array}{l}0.002291 \\
(<.0001)\end{array}$ & $\begin{array}{l}0.002308 \\
(<.0001)\end{array}$ & $\begin{array}{l}0.002339 \\
(<.0001)\end{array}$ \\
\hline Board Size $_{\mathrm{t}-1}$ & $\begin{array}{l}-0.00083 \\
(0.2659)\end{array}$ & $\begin{array}{l}-0.00094 \\
(0.2104)\end{array}$ & $\begin{array}{l}-0.00095 \\
(0.2007)\end{array}$ & $\begin{array}{l}-6.1 \mathrm{E}-05 \\
(0.9368)\end{array}$ & $\begin{array}{l}-0.00145 \\
(0.0412)\end{array}$ & $\begin{array}{l}-0.00117 \\
(0.1374)\end{array}$ \\
\hline Board Independence & $\begin{array}{l}-0.00607 \\
(0.0169)\end{array}$ & $\begin{array}{l}-0.00607 \\
(0.0154)\end{array}$ & $\begin{array}{l}-0.00605 \\
(0.0158)\end{array}$ & $\begin{array}{l}-0.0058 \\
(0.0303)\end{array}$ & $\begin{array}{l}-0.00588 \\
(0.0269)\end{array}$ & $\begin{array}{l}-0.00524 \\
(0.073)\end{array}$ \\
\hline Duality & $\begin{array}{l}0.00060 \\
(0.806)\end{array}$ & $\begin{array}{l}0.00060 \\
(0.8069)\end{array}$ & $\begin{array}{l}0.00060 \\
(0.8077)\end{array}$ & $\begin{array}{l}0.00090 \\
(0.6934)\end{array}$ & $\begin{array}{l}0.00072 \\
(0.7583)\end{array}$ & $\begin{array}{l}0.00032 \\
(0.8994)\end{array}$ \\
\hline Foreign Assets $_{\mathrm{t}-1}$ & $\begin{array}{l}-0.00003 \\
(0.8074)\end{array}$ & $\begin{array}{l}-0.00004 \\
(0.7393)\end{array}$ & $\begin{array}{l}-0.00004 \\
(0.7532)\end{array}$ & $\begin{array}{l}0.00003 \\
(0.8021)\end{array}$ & $\begin{array}{l}0.00001 \\
(0.9439)\end{array}$ & $\begin{array}{c}-0.00006 \\
(0.6361)\end{array}$ \\
\hline Foreign Sales $_{\mathrm{t}-1}$ & $\begin{array}{l}-0.00002 \\
(0.2232)\end{array}$ & $\begin{array}{l}-0.00002 \\
(0.2202)\end{array}$ & $\begin{array}{l}-0.00002 \\
(0.2261)\end{array}$ & $\begin{array}{l}-0.00002 \\
(0.3579)\end{array}$ & $\begin{array}{l}-0.00002 \\
(0.2251)\end{array}$ & $\begin{array}{l}-0.00002 \\
(0.2593)\end{array}$ \\
\hline Previous Cross Border Acquirer & $\begin{array}{l}0.002648 \\
(0.73)\end{array}$ & $\begin{array}{l}0.002705 \\
(0.7245)\end{array}$ & $\begin{array}{l}0.002856 \\
(0.7107)\end{array}$ & $\begin{array}{l}0.002204 \\
(0.7764)\end{array}$ & $\begin{array}{l}0.002407 \\
(0.756)\end{array}$ & $\begin{array}{l}0.001595 \\
(0.8357)\end{array}$ \\
\hline Intercept & $\begin{array}{l}0.396875 \\
(<.0001) \\
\end{array}$ & $\begin{array}{l}0.398526 \\
(<.0001) \\
\end{array}$ & $\begin{array}{l}0.397484 \\
(<.0001) \\
\end{array}$ & $\begin{array}{l}0.372301 \\
(<.0001) \\
\end{array}$ & $\begin{array}{l}0.384424 \\
(<.0001) \\
\end{array}$ & $\begin{array}{l}0.40349 \\
(<.0001) \\
\end{array}$ \\
\hline adj R squared & 0.1267 & 0.1264 & 0.1265 & 0.1292 & 0.1282 & 0.126 \\
\hline $\mathrm{N}$ & 9072 & 9072 & 9072 & 9072 & 9072 & 9072 \\
\hline Year Fixed effects & Yes & Yes & Yes & Yes & Yes & Yes \\
\hline Industry Fixed effects & Yes & Yes & Yes & Yes & Yes & Yes \\
\hline Clustered St errors at the country level & Yes & Yes & Yes & Yes & Yes & Yes \\
\hline
\end{tabular}


Table 14: Propensity score matching

Firms are matched on assets, ROA, foreign assets, foreign sales, leverage, cash, and board size. I compute the propensity that a firm has a foreign director using the following Probit model:

$$
\operatorname{Pr}(F D=1 \mid X)_{i, t}=\operatorname{Probit}\left[\alpha_{0}+\sum_{x=1}^{j} \gamma_{x} Z_{i, t}+e_{i, t}\right]
$$

Where $Z_{i, t}$ are the characteristics mentioned above. Based on this model, each firm gets a score based on the firm's characteristics. I match a firm with foreign director in a particular country in a particular year and industry with a firm with no foreign directors based on the nearest matched score. I do a t-test between these two groups of firms to examine their propensity to engage in cross-border mergers. *,**, and $* * *$ indicate significance at the $10 \%, 5 \%$, and $1 \%$ levels respectively. P-values are reported in parenthesis. The variable definitions are in the appendix.

\begin{tabular}{|c|c|c|c|c|}
\hline $\begin{array}{c}\text { Separation } \\
\text { Variable }\end{array}$ & & Cross-border merger & Num_CrossBorder & CrossBorder_Volume \\
\hline \multirow{2}{*}{ FD } & Firms with foreign directors & 0.5263 & 1.1979 & 573.9 \\
\hline & Firms without foreign directors & 0.3829 & 0.9864 & 358.9 \\
\hline & Test statistic & $17.65 * * *$ & $7.58 * * *$ & $5.5 * * *$ \\
\hline \multirow{2}{*}{ FDt-1 } & Firms with foreign directors & 0.5241 & 1.2369 & 577.3 \\
\hline & Firms without foreign directors & 0.3909 & 1.0737 & 383.6 \\
\hline & Test statistic & $16.27 * * *$ & $5.55 * * *$ & $4.97 * * *$ \\
\hline \multirow{2}{*}{ FDt-2 } & Firms with foreign directors & 0.5182 & 1.2646 & 595.1 \\
\hline & Firms without foreign directors & 0.387 & 1.1345 & 405.7 \\
\hline & Test statistic & $15.91 * * *$ & $4.25 * * *$ & $3.75^{* * *}$ \\
\hline \multirow{2}{*}{ FID } & Firms with foreign directors & 0.541 & 1.2858 & 592.7 \\
\hline & Firms without foreign directors & 0.4246 & 1.066 & 636.4 \\
\hline & Test statistic & $11.56 * * *$ & $6.94 * * *$ & -0.7 \\
\hline
\end{tabular}


Table 15: Heckman (1979) procedure

This table reports the results of the Heckman (1979) two-stage procedure. In the first stage, I estimate the determinants of appointing foreign directors in a particular firm.

$$
\operatorname{Pr}(F D=1 \mid X)_{i, t}=\operatorname{Probit}\left[\sum_{x=1}^{j} \gamma_{x} Z_{i, t}+\mu_{i}\right]
$$

Then, I compute the Inverse Mills Ratio (IMR) to estimate the second stage regressions. Panels A, B, and $\mathrm{C}$ reports the results of the second-stage analysis. Panel A reports the results from the Logit analysis after correcting for Heckman method. Panel B reports the results from the Poisson analysis after correcting for Heckman method. Panel C reports the results from the OLS analysis after correcting for Heckman method. *, **, and $* * *$ indicate significance at the $10 \%, 5 \%$, and $1 \%$ levels respectively. P-values are reported in parenthesis. The variable definitions are in the appendix.

Panel A: Logit Analysis

\begin{tabular}{|c|c|c|c|c|}
\hline & $(1)$ & $(2)$ & $(3)$ & $(4)$ \\
\hline FD & $\begin{array}{l}0.6066^{* * * *} \\
(<.0001)\end{array}$ & & & \\
\hline $\mathrm{FD}_{\mathrm{t}-1}$ & & $\begin{array}{l}0.5862 * * * \\
(<.0001)\end{array}$ & & \\
\hline $\mathrm{FD}_{\mathrm{t}-2}$ & & & $\begin{array}{l}0.5665 * * * \\
(<.0001)\end{array}$ & \\
\hline FID & & & & $\begin{array}{l}0.5374 * * * \\
(<.0001)\end{array}$ \\
\hline $\log (\text { Assets })_{\mathrm{t}-1}$ & $\begin{array}{l}0.0254 \\
(0.1531)\end{array}$ & $\begin{array}{l}0.0279 \\
(0.2336)\end{array}$ & $\begin{array}{l}0.0339 \\
(0.226)\end{array}$ & $\begin{array}{l}0.1176 \\
(<.0001)\end{array}$ \\
\hline $\mathrm{ROA}_{\mathrm{t}-1}$ & $\begin{array}{l}0.00177 \\
(0.2263)\end{array}$ & $\begin{array}{l}0.00176 \\
(0.2445)\end{array}$ & $\begin{array}{l}0.00163 \\
(0.2817)\end{array}$ & $\begin{array}{l}0.00154 \\
(0.2172)\end{array}$ \\
\hline Board Size $\mathrm{t}_{\mathrm{t}-1}$ & $\begin{array}{l}0.025 \\
(0.2386)\end{array}$ & $\begin{array}{l}0.0308 \\
(0.1945)\end{array}$ & $\begin{array}{l}0.038 \\
(0.1346)\end{array}$ & $\begin{array}{l}0.0993 \\
(<.0001)\end{array}$ \\
\hline Board Independence & $\begin{array}{l}-0.3607 \\
(<.0001)\end{array}$ & $\begin{array}{l}-0.3633 \\
(<.0001)\end{array}$ & $\begin{array}{l}-0.3644 \\
(<.0001)\end{array}$ & $\begin{array}{l}-0.469 \\
(<.0001)\end{array}$ \\
\hline Duality & $\begin{array}{l}-0.0112 \\
(0.5803)\end{array}$ & $\begin{array}{l}-0.0115 \\
(0.5727)\end{array}$ & $\begin{array}{l}-0.0115 \\
(0.5729)\end{array}$ & $\begin{array}{l}-0.00804 \\
(0.6868)\end{array}$ \\
\hline Foreign Assets $\mathrm{t}_{\mathrm{t}-1}$ & $\begin{array}{l}0.0215 \\
(<.0001)\end{array}$ & $\begin{array}{l}0.0222 \\
(<.0001)\end{array}$ & $\begin{array}{l}0.0232 \\
(<.0001)\end{array}$ & $\begin{array}{l}0.0325 \\
(<.0001)\end{array}$ \\
\hline Foreign Sales $_{\mathrm{t}-1}$ & $\begin{array}{l}0.00813 \\
(0.2387)\end{array}$ & $\begin{array}{l}0.00825 \\
(0.2378)\end{array}$ & $\begin{array}{l}0.00838 \\
(0.235)\end{array}$ & $\begin{array}{l}0.00981 \\
(0.1706)\end{array}$ \\
\hline IMR & $\begin{array}{l}-0.4507 \\
(0.727)\end{array}$ & $\begin{array}{l}-0.213 \\
(0.8898)\end{array}$ & $\begin{array}{l}0.1519 \\
(0.9312)\end{array}$ & $\begin{array}{l}5.3707 \\
(0.0019)\end{array}$ \\
\hline Intercept & $\begin{array}{l}-1.6203 \\
(0.2136) \\
\end{array}$ & $\begin{array}{l}-1.8447 \\
(0.2469) \\
\end{array}$ & $\begin{array}{l}-2.2156 \\
(0.2278) \\
\end{array}$ & $\begin{array}{l}-7.4507 \\
(<.0001) \\
\end{array}$ \\
\hline Pseudo -R square & 0.2553 & 0.2543 & 0.2534 & 0.2511 \\
\hline $\mathrm{N}$ & 25754 & 25754 & 25754 & 25754 \\
\hline Clustered St errors at the country level & Yes & Yes & Yes & Yes \\
\hline
\end{tabular}


Panel B: Poisson Analysis

\begin{tabular}{|c|c|c|c|c|}
\hline Log(Num_CrossBord & ${ }_{x} Z_{i, t}+\lambda 1$ & $e_{i, t}$ & (21) & \\
\hline & $(1)$ & $(2)$ & (3) & $(4)$ \\
\hline FD & $0.2833 * * *$ & & & \\
\hline & $(<.0001)$ & & & \\
\hline $\mathrm{FD}_{\mathrm{t}-1}$ & & $0.283 * * *$ & & \\
\hline & & $(<.0001)$ & & \\
\hline $\mathrm{FD}_{\mathrm{t}-2}$ & & & $0.2814 * * *$ & \\
\hline & & & $(<.0001)$ & \\
\hline FID & & & & $0.1404 * * *$ \\
\hline & & & & $(<.0001)$ \\
\hline $\log (\text { Assets })_{t-1}$ & 0.1396 & 0.1303 & 0.123 & 0.1677 \\
\hline & $(<.0001)$ & $(<.0001)$ & $(<.0001)$ & $(<.0001)$ \\
\hline $\mathrm{ROA}_{\mathrm{t}-1}$ & 0.0033 & 0.0037 & 0.0038 & 0.0028 \\
\hline & $(<.0001)$ & $(<.0001)$ & $(<.0001)$ & $(<.0001)$ \\
\hline Board Size ${ }_{t-1}$ & -0.0681 & -0.069 & -0.0694 & -0.0286 \\
\hline & $(<.0001)$ & $(<.0001)$ & $(<.0001)$ & $(<.0001)$ \\
\hline Board Independence & 0.035 & 0.0354 & 0.0378 & 0.0104 \\
\hline & $(0.0331)$ & $(0.0313)$ & $(0.0214)$ & $(0.5414)$ \\
\hline Duality & 0.0897 & 0.0897 & 0.0897 & 0.0922 \\
\hline & $(<.0001)$ & $(<.0001)$ & $(<.0001)$ & $(<.0001)$ \\
\hline Foreign Assets $\mathrm{t}_{\mathrm{t}-1}$ & 0.0034 & 0.003 & 0.0027 & 0.0091 \\
\hline & $(<.0001)$ & $(<.0001)$ & $(<.0001)$ & $(<.0001)$ \\
\hline Foreign Sales $_{\mathrm{t}-1}$ & 0.0001 & 0.0001 & 0.0001 & 0.0002 \\
\hline & $(<.0001)$ & $(<.0001)$ & $(0.002)$ & $(<.0001)$ \\
\hline IMR & -3.6492 & -3.914 & -4.1544 & -2.0046 \\
\hline & $(<.0001)$ & $(<.0001)$ & $(-4.1544)$ & $(-4.1544)$ \\
\hline Intercept & 0.1413 & 0.4612 & 0.7361 & -1.423 \\
\hline & $(0.5333)$ & $(0.0606)$ & $(0.0043)$ & $(<.0001)$ \\
\hline $\mathrm{N}$ & 25754 & 25754 & 25754 & 25754 \\
\hline
\end{tabular}


Panel C: OLS Analysis

CrooBorder_Volume $_{i, t}=\alpha_{0}+\beta_{1}(F D)_{i, t}+\sum_{x=1}^{j} \gamma_{x} Z_{i, t}+\lambda 1+e_{i, t}$

\begin{tabular}{|c|c|c|c|c|}
\hline & $(1)$ & $(2)$ & (3) & (4) \\
\hline FD & $\begin{array}{l}23.6^{*} \\
(0.0812)\end{array}$ & & & \\
\hline $\mathrm{FD}_{\mathrm{t}-1}$ & & $\begin{array}{l}28.6^{* *} \\
(0.0472)\end{array}$ & & \\
\hline $\mathrm{FD}_{\mathrm{t}-2}$ & & & $\begin{array}{l}30.9 * * \\
(0.0344)\end{array}$ & \\
\hline FID & & & & $\begin{array}{l}24.6 * * \\
(0.0269)\end{array}$ \\
\hline $\log (\text { Assets })_{\mathrm{t}-1}$ & $\begin{array}{l}-59.8 \\
(<.0001)\end{array}$ & $\begin{array}{l}-42.3 \\
(0.0074)\end{array}$ & $\begin{array}{l}-41.8 \\
(0.0161)\end{array}$ & $\begin{array}{l}-96.4 \\
(0.0011)\end{array}$ \\
\hline $\mathrm{ROA}_{\mathrm{t}-1}$ & $\begin{array}{l}-21.1 \\
(0.0029)\end{array}$ & $\begin{array}{l}-21.3 \\
(0.0029)\end{array}$ & $\begin{array}{l}-21.3 \\
(0.0031)\end{array}$ & $\begin{array}{l}-21.2 \\
(0.0035)\end{array}$ \\
\hline Board Size $\mathrm{t}_{\mathrm{t}-1}$ & $\begin{array}{l}-5.7 \\
(0.6591)\end{array}$ & $\begin{array}{l}11.2 \\
(0.1974)\end{array}$ & $\begin{array}{l}11 \\
(0.1863)\end{array}$ & $\begin{array}{l}-26.3 \\
(0.3354)\end{array}$ \\
\hline Board Independence & $\begin{array}{l}-56.4 \\
(0.0022)\end{array}$ & $\begin{array}{l}-56.4 \\
(0.0041)\end{array}$ & $\begin{array}{l}-56.7 \\
(0.0041)\end{array}$ & $\begin{array}{l}-51.5 \\
(0.0011)\end{array}$ \\
\hline Duality & $\begin{array}{l}-3.9 \\
(0.1317)\end{array}$ & $\begin{array}{l}-4.2 \\
(0.1214)\end{array}$ & $\begin{array}{l}-4.2 \\
(0.1238)\end{array}$ & $\begin{array}{l}-3.8 \\
(0.1392)\end{array}$ \\
\hline Foreign Assets $\mathrm{t}_{\mathrm{t}-1}$ & $\begin{array}{l}-0.5 \\
(0.8211)\end{array}$ & $\begin{array}{l}2.2 \\
(0.214)\end{array}$ & $\begin{array}{l}2.2 \\
(0.2154)\end{array}$ & $\begin{array}{l}-4.6 \\
(0.3554)\end{array}$ \\
\hline Previous Cross-Border Acquirer & $\begin{array}{l}-49 \\
(0.002)\end{array}$ & $\begin{array}{l}-42.6 \\
(0.0133)\end{array}$ & $\begin{array}{l}-43 \\
(0.0131)\end{array}$ & $\begin{array}{l}-47.8 \\
(0.0025)\end{array}$ \\
\hline IMR & $\begin{array}{l}-567.7 \\
(0.4291)\end{array}$ & $\begin{array}{l}538.1 \\
(0.3238)\end{array}$ & $\begin{array}{l}555.3 \\
(0.3313)\end{array}$ & $\begin{array}{l}-2926.4 \\
(0.2434)\end{array}$ \\
\hline Intercept & $\begin{array}{l}1556.9 \\
(0.0178) \\
\end{array}$ & $\begin{array}{l}469.6 \\
(0.4092) \\
\end{array}$ & $\begin{array}{l}453 \\
(0.4611) \\
\end{array}$ & $\begin{array}{l}3875.3 \\
(0.1047) \\
\end{array}$ \\
\hline adj-R square & 0.07607 & 0.07604 & 0.07605 & 0.07779 \\
\hline $\mathrm{N}$ & 25754 & 25754 & 25754 & 25754 \\
\hline Clustered St errors at the country level & Yes & Yes & Yes & Yes \\
\hline Industry fixed effects & Yes & Yes & Yes & Yes \\
\hline
\end{tabular}




\section{Appendix:}

\begin{tabular}{|c|c|c|}
\hline Variable & Definition & Source \\
\hline \#FD & The number of foreign directors in a firm in a year & BoardEx \\
\hline$\%$ Cash & The percentage of transaction that is paid in cash & SDC \\
\hline$\%$ FD on board & The percentage of foreign directors in a board relative to board size & BoardEx \\
\hline$\%$ of shares acquired & The percentage of shares acquired in a merger & SDC \\
\hline Assets & Total assets of a firm in a year & WorldScope \\
\hline Board Independence & The percentage of board members who are independent in a firm & BoardEx \\
\hline Board Size & The number of directors in a firm & BoardEx \\
\hline Book Value of Equity & The book value of a firm's equity & WorldScope \\
\hline CAR & Cumulative Abnormal return from a merger & Datastream \\
\hline $\mathrm{CD}$ (cultural distance) & $\begin{array}{l}\text { Cultural distance measure between the country of the foreign } \\
\text { director and the country of the target firm }\end{array}$ & $\begin{array}{l}\text { Hofstede } \\
\text { measures }\end{array}$ \\
\hline $\mathrm{CEO}$ & Binary variable equals to one if the director is the $\mathrm{CEO}$ of the firm & BoardEx \\
\hline Chair & $\begin{array}{l}\text { Binary variable equals to one if the director is the chairman of the } \\
\text { firm }\end{array}$ & BoardEx \\
\hline Cross-border merger & $\begin{array}{l}\text { A binary variable equals to one if the firm engaged in at least one } \\
\text { cross-border merger in a particular year }\end{array}$ & SDC \\
\hline D_Cash & $\begin{array}{l}\text { A binary variable that equals to one if the method of payment in a } \\
\text { merger is cash }\end{array}$ & SDC \\
\hline D_Mixed & $\begin{array}{l}\text { A binary variable that equals to one if the method of payment in a } \\
\text { merger is equity }\end{array}$ & SDC \\
\hline D_Mixed & $\begin{array}{l}\text { A binary variable that equals to one if the method of payment in a } \\
\text { merger is mixed }\end{array}$ & SDC \\
\hline Debt/TA & Liabilities over total assets & WorldScope \\
\hline Duality & $\begin{array}{l}\text { Binary variable equals to one if the director is both the CEO and } \\
\text { chairman of the board }\end{array}$ & BoardEx \\
\hline FD & $\begin{array}{l}\text { Binary variable equals to one if the firm has at least one foreign } \\
\text { director }\end{array}$ & BoardEx \\
\hline FID & $\begin{array}{l}\text { Binary variable equals to one if the firm has at least one foreign } \\
\text { independent director }\end{array}$ & BoardEx \\
\hline Foreign Assets & $\begin{array}{l}\text { The percentage of assets of a firm which are incorporated in a } \\
\text { foreign country }\end{array}$ & WorldScope \\
\hline Foreign Sales & The percentage of a firm's sales coming from other countries & WorldScope \\
\hline Hostile mergers & $\begin{array}{l}\text { A binary variable equals to one if a firm engaged in a hostile } \\
\text { merger }\end{array}$ & SDC \\
\hline Independent & $\begin{array}{l}\text { Binary variable equals to one if the director is independent (non- } \\
\text { executive director) }\end{array}$ & BoardEx \\
\hline Market value & Market capitalization of a firm at the end of fiscal year & WorldScope \\
\hline Merger & $\begin{array}{l}\text { A binary variable equals to one if the firm engaged in at least one } \\
\text { merger in a particular year }\end{array}$ & SDC \\
\hline Previous cross-border Acquirer & $\begin{array}{l}\text { A binary variable equals to one if the acquirer in a merger had a } \\
\text { previous cross-border merger }\end{array}$ & SDC \\
\hline Private target & A binary variable equals to one if the target of a merger is private & SDC \\
\hline Purchase price & The total value of the transaction of a merger & SDC \\
\hline Relative deal size & The purchase price / Total assets & $\begin{array}{l}\text { SDC / } \\
\text { WorldScope }\end{array}$ \\
\hline ROA & Return on Assets & WorldScope \\
\hline
\end{tabular}




\section{VITA}

Yaqoub Alabdullah was born in Kuwait in 1983 to parents Ahmad and Naeema. He graduated high school in 2001 and was honored by the Amir of Kuwait for being the second best high school graduate in Kuwait. He got his bachelor's degree from Kuwait University in Accounting in 2008 and a Masters of Business Administration from the University of Texas at Arlington in 2010. Yaqoub is honored to have received many awards and recognitions throughout his educational career from several Kuwaiti officials and institutions.

Yaqoub is married to his wife Fatma since 2010 and they have 2 young boys. Ahmad is three years and Sulaiman is only one month old. Yaqoub's family has a huge influence on him and everything he does. Yaqoub's father is a successful politician in Kuwait. He was the minister of Justice and the minister of commerce for five and two years respectively. He was also a member of the parliament for twenty five years. Yaqoub sees his father as an example of how a successful man can be.

Yaqoub is going to be an Assistant Professor in Kuwait University in the upcoming years. He wishes to transform the finance department at Kuwait University to be more research oriented and to help build better economic policy in Kuwait and the Middle East. 